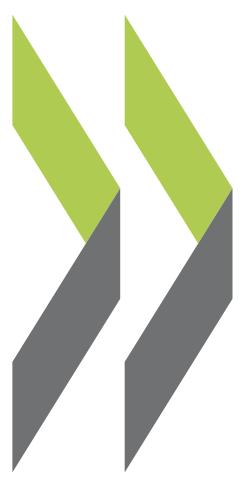

OECD Working Papers on Finance, Insurance and Private Pensions No. 43

\title{
Financial Education for MSMEs and Potential Entrepreneurs
} Adele Atkinson 


\title{
Financial Education for MSMEs and Potential Entrepreneurs
}

\author{
OECD Working Papers should not be reported as representing the official views of the OECD or \\ of its member countries. The opinions expressed and arguments employed are those of the \\ authors. \\ Working Papers describe preliminary results or research in progress by the author(s) and are \\ published to stimulate discussion on a broad range of issues on which the OECD works. \\ Comments on Working Papers are welcomed, and may be sent to daf.contact@oecd.org or the \\ Financial Affairs Division, Directorate for Financial and Enterprise Affairs, OECD, 2 rue André \\ Pascal, 75775 Paris Cedex 16, France.
}

OECD Working Papers on Finance, Insurance and Private Pensions provide timely analysis and background on industry developments, structural issues, and public policy in the financial sector, including insurance and private pensions. Topics include risk management, governance, investments, benefit protection, and financial education.

\section{OECD WORKING PAPERS ON FINANCE, INSURANCE AND PRIVATE PENSIONS \\ are published on www.oecd.org/daf/fin/wp}

This document and any map included herein are without prejudice to the status of or sovereignty over any territory, to the delimitation of international frontiers and boundaries and to the name of any territory, city or area.

The statistical data for Israel are supplied by and under the responsibility of the relevant Israeli authorities. The use of such data by the OECD is without prejudice to the status of the Golan Heights, East Jerusalem and Israeli settlements in the West Bank under the terms of international law.

This report is circulated under the responsibility of the Secretary-General of the OECD. The opinions expressed and arguments employed herein do not necessarily reflect the official views of OECD member countries or of the G20.

This document and any map included herein are without prejudice to the status of or sovereignty over any territory, to the delimitation of international frontiers and boundaries and to the name of any territory, city or area.

\section{(C) OECD 2017}

You can copy, download or print OECD content for your own use, and you can include excerpts from OECD publications, databases and multimedia products in your own documents, presentations, blogs, websites and teaching materials, provided that suitable acknowledgment of OECD as source and copyright owner is given. All requests for commercial use and translation rights should be submitted to rights@oecd.org. 


\title{
Financial Education for MSMEs and Potential Entrepreneurs
}

\author{
by \\ Adele Atkinson*
}

\begin{abstract}
Micro, small and medium-sized enterprises (MSMEs) make up the majority of enterprises in the world, providing employment and contributing significantly to national incomes. Many MSMEs face a number of challenges, including regulatory hurdles and tax burdens, difficulties accessing finance and a lack of general guidance or support. Financial education can be an important tool for helping MSMEs and potential entrepreneurs to obtain access to finance and strengthen money management skills.

This working paper presents the results of a stocktake of 21 economies. It shows that, while some MSMEs have access to education, training or mentoring, in most economies approaches are fragmented and risk missing important groups. Identifying MSMEs as a target group within national strategies for financial education would contribute to addressing some of the challenges they face. This would also underline the importance of measuring levels of financial literacy among MSMEs and help policy makers and stakeholders to evaluate programmes that target this group.
\end{abstract}

Authorised for release by Pierre Poret, Director, OECD Directorate for Financial and Enterprise Affairs

Keywords: financial education, financial consumer protection, micro-enterprise, SME, entrepreneur

Adele Atkinson is a Senior Policy Analyst in the OECD Directorate for Financial and Enterprise Affairs. 


\section{Table of contents}

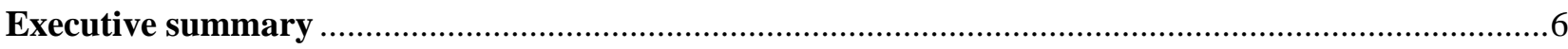

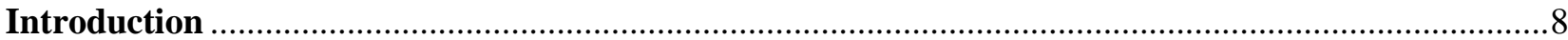

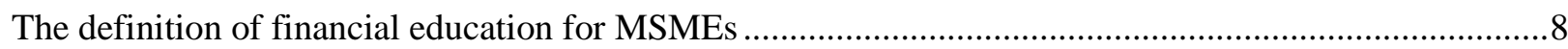

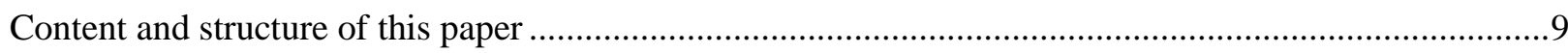

Section I. The importance of MSMEs and the challenges they face …................................................10

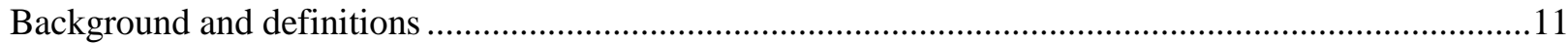

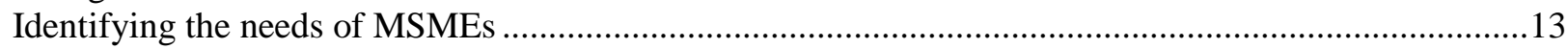

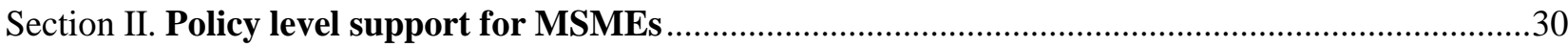

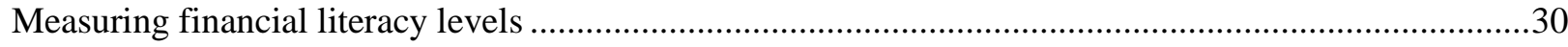

Targeting MSMEs through national strategies for financial education .................................................30

Targeting MSMEs through other national frameworks ….........................................................................

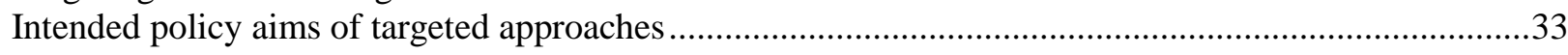

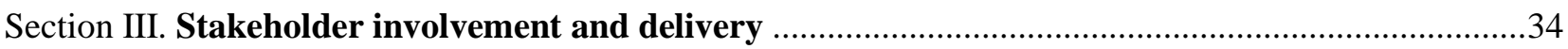

Stakeholders providing financial education, practical support and guidance to MSMEs..........................34

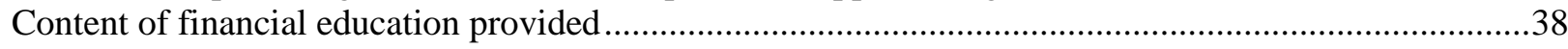

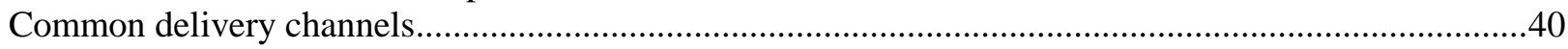

Delivery methods

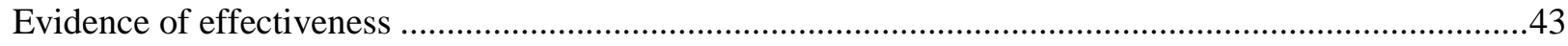

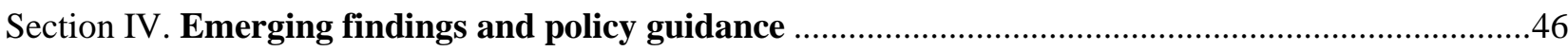

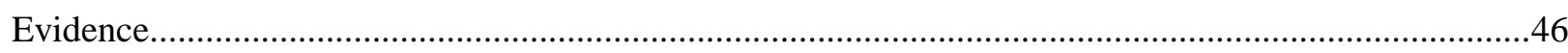

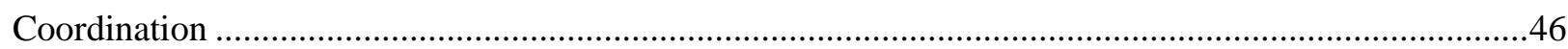

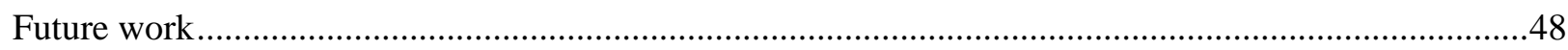

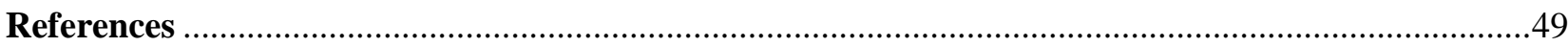

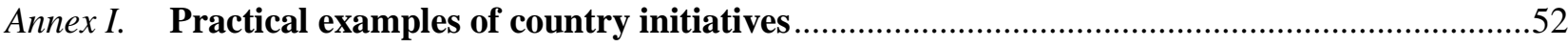

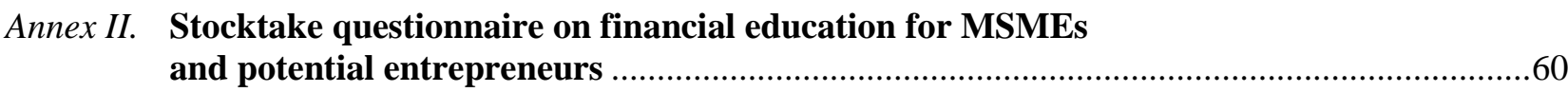

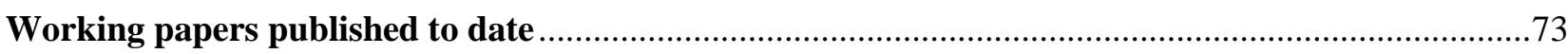

Tables

Table 1. Approach to defining size of enterprise..........................................................................

Table 2. MSME contribution to employment, percentage of all business and contribution to GDP ..13

Table 3. Challenges faced by MSMEs within the business landscape .............................................15

Table 4. Interest rate spreads between loans to SMEs and to large enterprises, 2007-14 _...............18

Table 5. Challenges faced by MSMEs in terms of skills and experiences of entrepreneurs ...............28 


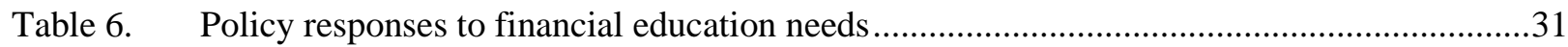

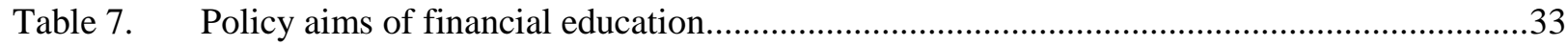

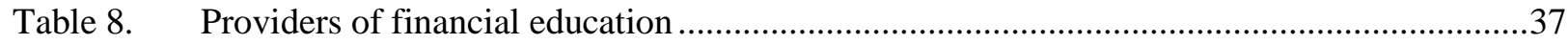

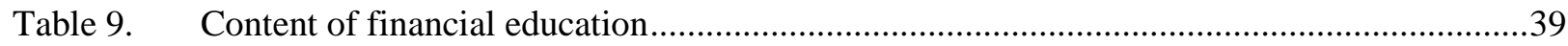

Table 10. Delivery channels and methods used for financial education...............................................41

\section{Figures}

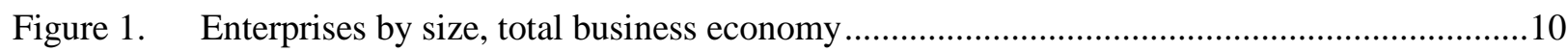

Figure 2. Employment by enterprise size, total business economy ……........................................12

Figure 3. The 10 most burdensome legislative acts for MSMEs in Europe......................................14

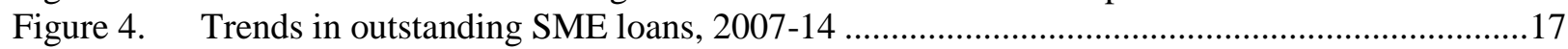

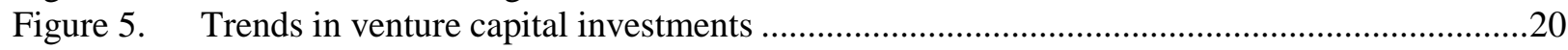

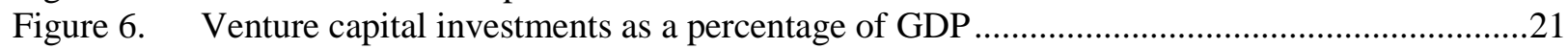

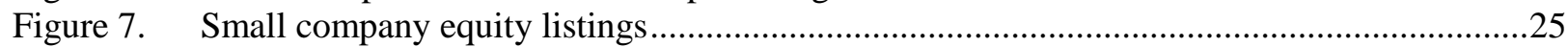

Figure 8. Improving financial literacy skills for access to finance ................................................27

\section{Boxes}

Box 1. Working definition of financial education for MSMEs .....................................................

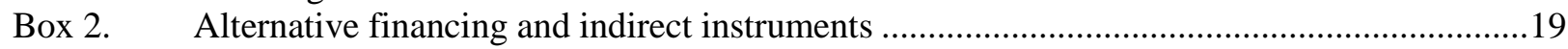

Box 3. Financial education and FinTech: the case of marketplace lending and crowdfunding .........22

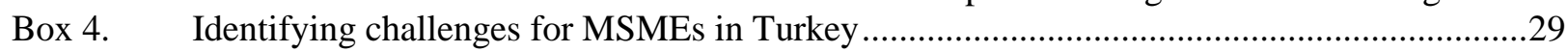

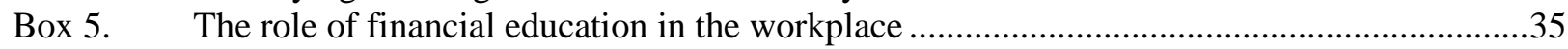

Box 6. The Elite Platform of the London Stock Exchange Group.....................................................36 


\section{Executive summary}

Micro, small and medium-sized enterprises (MSMEs) make up the majority of enterprises in the world, providing employment and contributing significantly to national incomes. They can therefore play an important role in sustainable, inclusive economic growth and development and improved financial stability given appropriate conditions and timely support.

In recognition of this, the OECD International Network on Financial Education (OECD/INFE) decided to explore the extent to which MSMEs are considered to be a target group for financial education, and to create dedicated policy research and tools to support efforts to address their specific challenges and needs. A first progress report was submitted to G20 leaders at their meeting in Antalya in September 2015, and a stocktake questionnaire was circulated to OECD/INFE members at the end of 2015 to inform a detailed study of current efforts to provide financial education to this important group. This paper summarises the results of that exercise and the supporting literature. It will feed into current work to develop a core competency framework for MSMEs as well as the creation of a specific measurement tool to assess levels of financial literacy among this group.

MSMEs stand to benefit from an economically sound business environment that stimulates investment and promotes entrepreneurship. However, many currently face a number of challenges, including regulatory hurdles and tax burdens, difficulties accessing finance and a lack of general guidance or support. These can have a variety of negative impacts that will ultimately constrain the contribution of MSMEs by slowing down their development and growth.

In addition to structural challenges, the stocktake also indicates that potential entrepreneurs may also lack skills that could help them in the creation and growth of new enterprises, including entrepreneurial and business skills and financial literacy. Unfortunately it is difficult to quantify the size of this problem fully as relatively few national strategies for financial education target MSMEs specifically and there is therefore a lack of data on entrepreneurs' skills.

Whilst financial education strategies tend to target private individuals rather than businesses, there is a wide range of financial education available from different stakeholders via other avenues. In 17 of the 21 countries responding to the survey, the public sector provides some education, support or guidance to MSMEs, whilst other sectors including education, industry organisations, not-for-profits and the financial sector are also involved in delivering some kind of support to this target group. In this way, the stocktake indicates most kinds of MSMEs and potential entrepreneurs have access to basic financial education of relevance in the business context, although the extent of coverage of such provision is varied and may only occur at a local or regional level.

Almost all responding countries report that financial education and entrepreneurship education is available in school or university at some level, reflecting the likelihood of young people being offered the possibility to learn business skills during their compulsory or higher education. Beyond formal education, individuals may also receive training, education or mentoring through a variety of programmes, although leaflets and printed materials are the most common delivery mechanism for financial education beyond school, suggesting a focus on information dissemination rather than structured guidance. At the same time, 
digital delivery of financial education for this group is becoming more common, with social media being used in Australia, Bangladesh, Chile, China, Estonia, Indonesia, Japan and Kenya.

Evaluation has not been a priority for stakeholders providing financial education to MSMEs, meaning that it is currently impossible to draw firm conclusions about the efficacy of current policies or programmes. More work is needed to create specific tools to measure the financial literacy of entrepreneurs, and to evaluate initiatives designed to improve levels of financial literacy among this group.

The paper concludes by noting that a coordinated approach that brings together the various stakeholders providing financial education to MSMEs could help to streamline the currently fragmented delivery and close any gaps in provision. This may require an approach that targets different sized MSMEs, and those at different stages of development with tailor-made information, education and guidance delivered through a number of different channels, including more innovative, digital platforms. Regular data collection will be essential to develop and implement evidence-based policies and monitoring and evaluation should be designed into such policies to prove their effectiveness or highlight where changes are necessary.

The paper was prepared by Adele Atkinson with contributions from Iota Nassr and oversight by Flore-Anne Messy, all OECD. Editorial support within the OECD was provided by Pamela Duffin, Jennah Huxley and Edward Smiley. It takes into account insights and feedback from members of the OECD/INFE and OECD colleagues at the Centre for Entrepreneurship, SMEs, Local Development and Tourism. 


\section{Introduction}

Micro, small and medium-sized enterprises (MSMEs) make up the majority of enterprises in the world, providing employment and contributing significantly to national incomes. They can play an important role in sustainable, inclusive economic growth and development and improved financial stability given appropriate conditions and timely support.

In recognition of this, the OECD International Network on Financial Education (OECD/INFE) Advisory Board and its Technical Committee created a dedicated Expert Subgroup on Financial Education for MSMEs. This initiative complements work on small and medium-sized enterprise (SME) financing by the OECD Committee on Financial Markets and the OECD Centre for Entrepreneurship, SMEs and Local Development (CFE), which focuses on supply side issues. ${ }^{1}$ Outputs from these three initiatives inform the global and G20 agenda on SME financing.

The OECD/INFE progress report submitted to G20 leaders at their meeting in Antalya in September 2015 highlights existing OECD outputs on MSMEs, current international and national approaches to supporting entrepreneurs and the role of financial education. It also lays out a roadmap of activities.

The progress report indicates that whilst the contribution of MSMEs to national economies is widely recognised, their financial education needs are not always being met and low levels of financial literacy pose a potential barrier to successful business creation and growth. It proposes a stocktaking exercise to identify the main policy challenges and good practices.

The OECD/INFE therefore developed a stocktake questionnaire (see Annex) to gather information from member countries. Responses were received from 21 countries and economies between September 2015 and February 2016. The main focus of the stocktake was on micro and small enterprises (with a suggested maximum of 100 employees), and potential entrepreneurs (i.e. individuals with potential business ideas who are close to taking their ideas to the market).

\section{The definition of financial education for MSMEs}

The OECD/INFE progress report includes a working definition of financial education, created to focus the work of the expert subgroup on the key aspects of financial literacy and financial education that are specific to MSMEs (Box 1). It also notes that whilst the definition does not discuss how financial education needs differ according to the size of an enterprise, the work will primarily focus on micro and small enterprises, and potential entrepreneurs. ${ }^{2}$ However, as the definitions of micro, small and mediumsized enterprises vary by country - and in some cases, industry - the decision of how to apply the working definition below should be made at the country level.

1 The OECD/INFE serves the OECD Committee on Financial Markets and the OECD Insurance and Private Pensions Committee, both within the OECD Directorate for Financial and Enterprise Affairs.

2 It should be noted, however, that some parts of the report address issues related to the upper end of the MSME and SME size spectrum, as in the case of capital market financing, where the discussion covers the entire SME group and not just micro and small enterprises. 


\section{Box 1. Working definition of financial education for MSMEs}

Financial education for MSMEs and potential entrepreneurs takes into account different types of business and stages of enterprises, and refers to the process by which they:

- recognise the interaction between personal and business finance;

- $\quad$ know where to go for help;

- improve their understanding of the financial landscape, products and concepts of relevance; and

- through information, instruction and/or objective advice, develop the skills, knowledge, attitudes and confidence to:

- become more aware of financing opportunities and financial risks and opportunities;

- make informed business plans and related choices;

- manage their financial records, planning and risks effectively over the short and long term; and

- take other effective actions to maximise the potential of their business for the benefit of their enterprise and that of the wider economy.

\section{Content and structure of this paper}

This paper draws on responses to the OECD/INFE stocktake to describe the challenges faced and the demand-side approaches taken to encourage and support new entrants and strengthen existing MSMEs through the provision of financial education. It also highlights key findings from OECD work on SMEs and other research and policy documents. It is a complement to OECD 2017a, which draws on the responses to the stocktake to focus on financial education for MSMEs in Asia.

The paper has 5 sections. Section I provides background information on the definition of MSMEs and their importance; and discusses the needs of MSMEs, focusing particularly on access to finance and financial literacy needs. Section II looks at the extent to which policy frameworks include elements of support for entrepreneurs and businesses, and the intended aims of such frameworks. In Section III, the focus is on practical involvement by stakeholders, the content of the education provided and the typical delivery channels and methods. Section IV summarises emerging findings and policy guidance based on discussion with OECD/INFE members and related evidence. Annex I provides additional information about some of the initiatives underway in a selection of countries and the stocktake questionnaire is reproduced in Annex II.

In each section of the paper, the primary focus is on micro and small enterprises and potential entrepreneurs, rather than medium-sized, reflecting the importance of providing tailored financial education to the smaller players; the focus is also more on the basic financial literacy needs of people managing such enterprises than the financial skills necessary to undertake activities such as negotiating complex financing arrangements with venture capitalists or preparing a medium-sized company's accounts for tax purposes. For the sake of brevity, the text below uses the acronym MSMEs to represent this target group. Recognising the diversity of MSMEs, discussion may also consider enterprises according to their life stage (new, growth, mature). Much less information is available about financial education by sector and so this is not discussed in detail. 


\section{Section I. The importance of MSMEs and the challenges they face}

Micro, small and medium-sized enterprises (MSMEs) - and particularly micro and small enterprises make up the majority of enterprises in the world (see Figure 1 for example), providing employment and contributing significantly to national incomes. They are considered to be vital to the economy in all countries responding to the OECD/INFE stocktake; on different continents and across levels of economic development. ${ }^{3}$

Figure 1. Enterprises by size, total business economy

Percentage of all enterprises, 2013, or latest available year

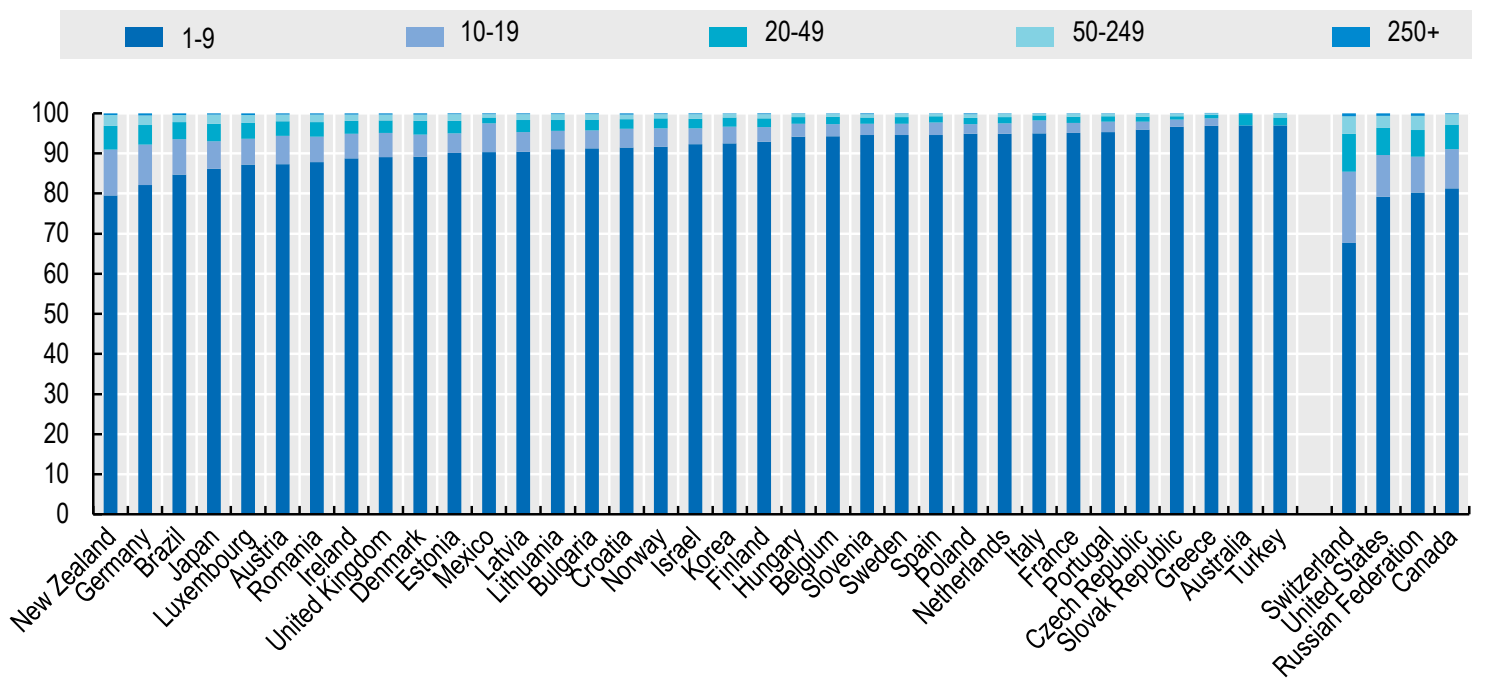

Source: OECD SDBS database, reported in OECD (2016). http://dx.doi.org/10.1787/888933403628

Such enterprises cover all sectors of an economy, from health and social services, through to technology, engineering, agriculture or tourism; although in some countries they may be highly focused in certain fields. They include both thriving companies with highly driven innovative managers that are motivated to develop, and the reluctant self-employed who may be earning low incomes and have no intention of growing their business or expanding their horizons. They also include both those that have been created in the last year and family businesses with a history that goes back several generations.

Enterprises may be operating within the formal sector or outside (in the so-called informal or shadow economy). This is true in developed countries as well as emerging economies (see for example Andrews et al, 2011).

3. Readers may also be interested in the recent in-depth OECD study of Trends in SME Performance and Business Conditions (OECD (2017b). 


\section{Background and definitions}

\section{Defining enterprises}

The different types and sizes of enterprise are usually defined at the national level in order to categorise them for accounting legislation and tax purposes. The typical approach is to discuss the size of an enterprise according to the number of employees and/or turnover (Table 1). Some countries also specifically include a statement about independence in the definition, and some create a definition that involves meeting two out of three criteria. The definition sometimes varies by sector, but this is not a universal approach. Kenya appears to be unusual in also considering the informal sector explicitly in definitions and measures of entrepreneurial activities.

Table 1. Approach to defining size of enterprise

\begin{tabular}{|c|c|c|}
\hline Country & Factors included in the definition & Variation by Sector? \\
\hline Australia & Definition of small business is not universal in Australian context & \\
\hline Bangladesh & Income & $\begin{array}{l}\text { Yes } \\
\text { (manufacturing/service) }\end{array}$ \\
\hline Brazil & Gross revenue for micro and small enterprises & \\
\hline Chile & Employees and annual sales & No \\
\hline China & Employees and sales income & Yes \\
\hline Colombia & Employees, and value of financial assets & No \\
\hline Czech Republic & $\begin{array}{l}\text { Employees and annual turnover or balance sheet. Additional } \\
\text { criteria relate to independence }\end{array}$ & No \\
\hline Denmark & $\begin{array}{l}\text { Employees with a lower level of activity, designed to filter out } \\
\text { hobbyists }\end{array}$ & No \\
\hline Estonia & $\begin{array}{l}\text { Employees and turnover or balance sheet. Firms that are part of a } \\
\text { larger group may be counted according to the group }\end{array}$ & No \\
\hline Hong Kong, China & Employees & \\
\hline India & & $\begin{array}{l}\text { Yes } \\
\text { (manufacturing/service) }\end{array}$ \\
\hline Indonesia & $\begin{array}{l}\text { Employees and net assets or annual sales. Definition of medium- } \\
\text { sized also includes a measure of independence }\end{array}$ & $\begin{array}{l}\text { A wide variety of sectors } \\
\text { are identified separately }\end{array}$ \\
\hline Italy & Employees and turnover & No \\
\hline Jamaica & Employees and annual sales/turnover & No \\
\hline Japan & Employees and capital & Yes \\
\hline Kenya & Employees and turnover and/or balance sheet & $\begin{array}{l}\text { Yes, based on annual } \\
\text { turnover }\end{array}$ \\
\hline Korea & Employees and capital or sales & Yes \\
\hline Portugal & Employees, turnover and balance sheet & No \\
\hline Romania & Employees and turnover and/or balance sheet & No \\
\hline Serbia & $\begin{array}{l}\text { Employees for micro enterprise; employees and value of business } \\
\text { property for small; employees, value of business property and } \\
\text { turnover for medium-sized }\end{array}$ & No \\
\hline Slovenia & $\begin{array}{l}\text { Based on satisfying two of three criteria relating to employees, net } \\
\text { proceeds from sales and value of assets }\end{array}$ & $\begin{array}{l}\text { Variation in financial } \\
\text { sector (all banks, } \\
\text { insurance companies and } \\
\text { stock exchanges } \\
\text { considered to be large) }\end{array}$ \\
\hline Spain & Employees and turnover or balance sheet & No \\
\hline Turkey & Employees and annual net sales or balance sheet & No \\
\hline
\end{tabular}

Responses to stocktake. Responding countries not listed had limited or no information for this section; similarly empty cells indicate that the information was not available. 


\section{The contribution of MSMEs}

The most recent OECD data indicate that micro and small enterprises make a considerable contribution to overall employment in many countries, although there is a wide variation (Figure 2).

Figure 2. Persons employed by enterprise size, total business economy

Percentage of all persons employed, 2013, or latest available year

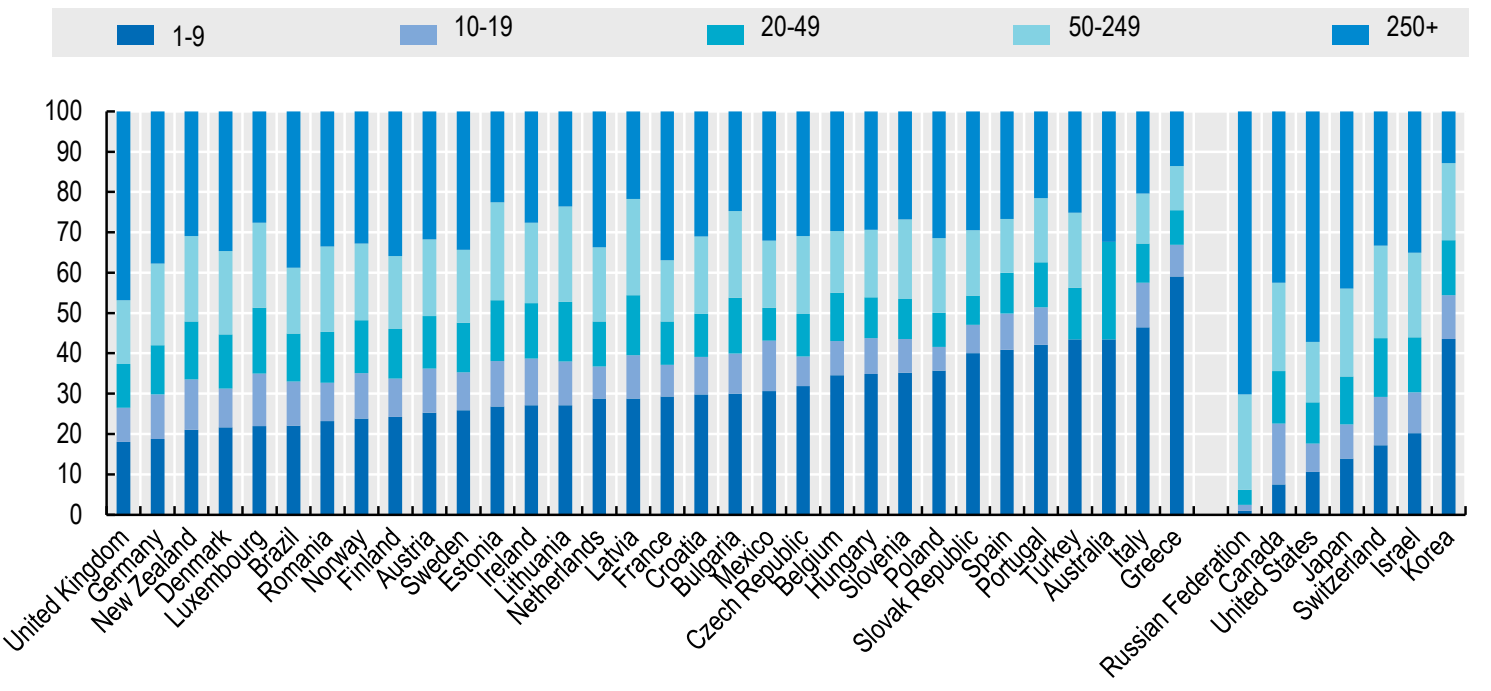

Source: OECD SDBS database, reported in OECD (2016). http://dx.doi.org/10.1787/888933403708

Whilst it is difficult to get comparable data due to the combination of different definitions and measurement regimes, the overall picture illustrated in Table 2 corroborates the OECD/INFE data, indicating that MSMEs make up the vast majority of businesses in every country, and typically contribute over half of total employment. The share of employment by size of enterprise varies notably by country, with the impact of micro-enterprises being particularly significant in Italy and Indonesia.

There is a large variation in the contribution of MSMEs to GDP across those countries where authorities participating in the stocktake exercise were able to access such data, from a relatively low $27 \%$ in Brazil, through to almost 76\% in Estonia (Table 2). 
Table 2. MSME contribution to employment, percentage of all business and contribution to GDP

\begin{tabular}{|c|c|c|c|c|}
\hline & $\begin{array}{l}\text { Micro- } \\
\text { enterprises } \\
\text { (\% of } \\
\text { employment) }\end{array}$ & $\begin{array}{l}\text { Small } \\
\text { enterprises } \\
\text { (\% of } \\
\text { employment) }\end{array}$ & $\begin{array}{l}\text { Medium- } \\
\text { sized } \\
\text { enterprises } \\
\text { (\% of } \\
\text { employment) }\end{array}$ & MSMES \\
\hline Australia & & & & $\begin{array}{l}\text { MSMEs make up } 99 \% \text { of businesses. Micro and } \\
\text { small contributed } 33 \% \text { of private industry value and } \\
\text { provided } 43 \% \text { of private sector employment }\end{array}$ \\
\hline Brazil & & & & $\begin{array}{l}\text { Together, all MSMEs contribute } 27 \% \text { of GDP and } \\
52 \% \text { of employment. }\end{array}$ \\
\hline Chile & $6.9 \%$ & $23.5 \%$ & $17.2 \%$ & \\
\hline China & & & & MSMEs contribute $60 \%$ of GDP \\
\hline Colombia & & & & TMSMEs make up $88.8 \%$ of all companies \\
\hline $\begin{array}{l}\text { Czech } \\
\text { Republic }\end{array}$ & & & & $\begin{array}{l}60 \% \text { of employees within the private sector are in } \\
\text { MSMEs and make up } 99.8 \% \text { of all enterprises } \\
(2013)\end{array}$ \\
\hline Denmark & $14.4 \%$ & $16.5 \%$ & $15.2 \%$ & MSMEs make up $99.7 \%$ of all enterprises \\
\hline Estonia & $30.9 \%$ & $24.2 \%$ & $23.0 \%$ & $\begin{array}{l}\text { MSMEs make up } 99.7 \% \text { of all enterprises and } 75.6 \% \\
\text { of GDP }\end{array}$ \\
\hline $\begin{array}{l}\text { Hong } \\
\text { Kong, } \\
\text { China }\end{array}$ & & & & $\begin{array}{l}\text { MSMEs make up approx. } 98 \% \text { of all enterprises and } \\
\text { provide } 50 \% \text { of employment }\end{array}$ \\
\hline India & & & & $\begin{array}{l}\text { MSMEs provide } 37.54 \% \text { of GDP and } 12.5 \% \text { of } \\
\text { employment }\end{array}$ \\
\hline Indonesia & $\begin{array}{l}\text { 88.9\% of } \\
\text { MSME } \\
\text { employment }\end{array}$ & $\begin{array}{l}.73 \% \text { of } \\
\text { MSME } \\
\text { employment }\end{array}$ & $\begin{array}{l}\text { 3.36\% of } \\
\text { MSME } \\
\text { employment }\end{array}$ & MSMEs contribute $60.34 \%$ of GDP (2013) \\
\hline Italy & $46.6 \%$ & $19.6 \%$ & $12.6 \%$ & \\
\hline Japan & & $\begin{array}{l}23.1 \% \text { of } \\
\text { employment, } \\
16.1 \% \text { of } \\
\text { GDP }\end{array}$ & $\begin{array}{l}46.5 \% \text { of } \\
\text { employment, } \\
38.5 \% \text { of } \\
\text { GDP }\end{array}$ & $\begin{array}{l}\text { MSMEs provide } 54.5 \% \text { of GDP and } 69.6 \% \text { of } \\
\text { employment. MSMEs account for } 99.7 \% \text { of } \\
\text { companies. }\end{array}$ \\
\hline Korea & $37.7 \%$ & $24.4 \%$ & $25.4 \%$ & $\begin{array}{l}\text { MSMEs make up } 99.9 \% \text { of all enterprises and } \\
\text { provide } 87.5 \% \text { of employment }\end{array}$ \\
\hline Portugal & $46.4 \%$ & $\begin{array}{l}18.6 \% \text { of } \\
\text { employment }\end{array}$ & $14.3 \%$ & $\begin{array}{l}\text { MSMEs provide } 79.3 \% \text { of employment and count for } \\
99.9 \% \text { of companies (2013) }\end{array}$ \\
\hline Serbia & & & & $\begin{array}{l}\text { MSMEs provide } 64.9 \% \text { of employment and account } \\
\text { for } 99.8 \% \text { of all companies }\end{array}$ \\
\hline Slovenia & $29 \%$ & $17 \%$ & $24 \%$ & $\begin{array}{l}\text { MSMEs provide } 69 \% \text { of employment and account for } \\
99.8 \% \text { of companies }\end{array}$ \\
\hline Spain & $32.6 \%$ & $18.6 \%$ & $14.8 \%$ & $\begin{array}{l}\text { MSMEs provide } 66 \% \text { of employment and account for } \\
99.9 \% \text { of companies }\end{array}$ \\
\hline Turkey & & & & $\begin{array}{l}\text { MSME provide } 75.8 \% \text { of employment and sales are } \\
63.3 \% \text { of GDP }\end{array}$ \\
\hline
\end{tabular}

Responses to stocktake. Responding countries not listed had limited or no information for this section; similarly empty cells indicate that the information was not available.

\section{Identifying the needs of MSMEs}

It is clear that policy makers recognise that MSMEs are already making a significant contribution to national economies. In order to maximise this, it is important to identify their specific needs, take note of gaps and seek ways to address them. 


\section{An Enabling Environment}

An economically sound, stable, and business-friendly environment stimulates investment, promotes entrepreneurship and can boost MSME development and activity. Certainty of the legal and regulatory environment (including the restructuring and resolution framework), a stable tax framework and availability of financing are all enabling factors.

\section{Regulation and tax}

Regulatory hurdles are seen as an issue in almost all countries participating in the stocktake, and seem to particularly affect potential entrepreneurs and new enterprises (Table 3). In some countries these hurdles impact all enterprises, including the mature ones (Brazil, Denmark, Indonesia, Serbia and Spain). Denmark and Indonesia reported that efforts are underway to tackle the issues identified. Some countries noted that tax laws were a particular challenge that they were trying to address, although this was not specifically asked.

While regulation intends to correct for market failures and information asymmetries and improve the balance between the objectives of different stakeholders, regulatory barriers can be a burden on businesses, particularly MSMEs. Regulation and a heavy administrative burden linked to the creation of a company can raise the costs of entering a market overall. Such costs are proportionally higher for smaller enterprises, because regulation typically entails a fixed cost. With no dedicated personnel and other resources to deal with the regulatory requirements an entrepreneur may also end up reallocating time away from business operations in order to deal with regulation (EC, 2007; Nassr et al., 2016).

In a 2012 survey conducted by the European Commission, the top ten most burdensome administrative acts for SMEs were identified. The top dimensions identified by SMEs as most burdensome were: dealing with taxation, with product safety standards, and with employment legislation (Figure 3).

Figure 3. The 10 most burdensome legislative acts for SMEs in Europe

In percentages

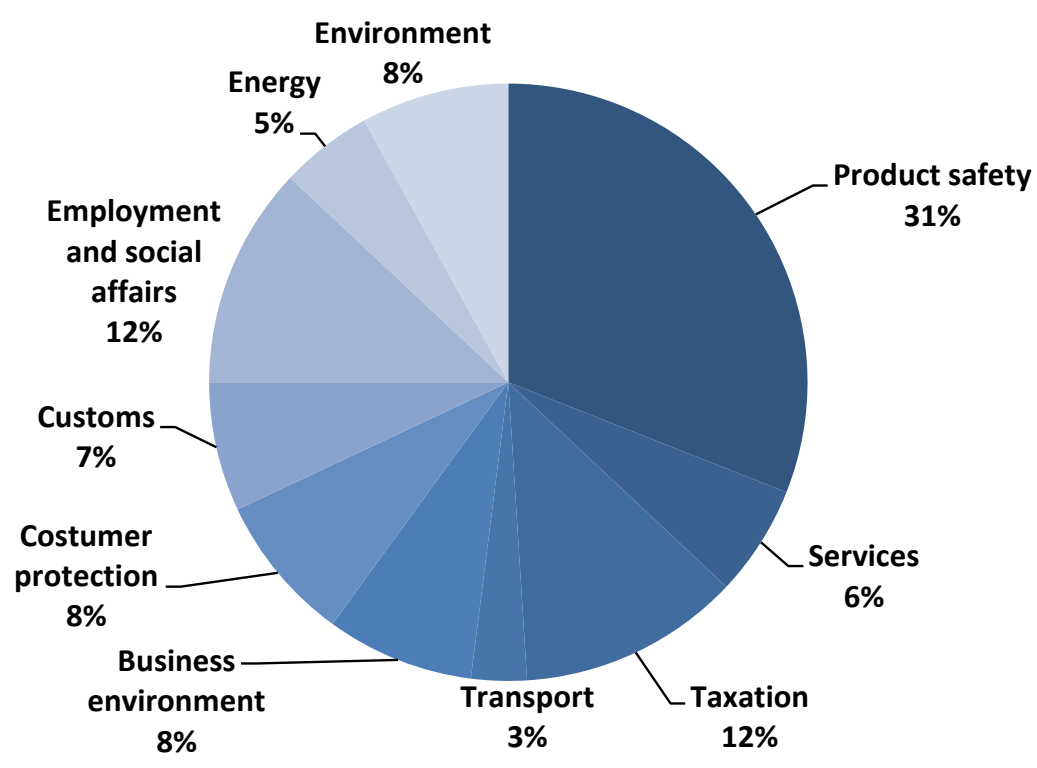

Source: European Commission (2013a) 
Table 3. Challenges faced by MSMEs within the business landscape

\begin{tabular}{|c|c|c|c|c|c|}
\hline \multirow[b]{2}{*}{ Country } & \multicolumn{4}{|c|}{$\begin{array}{l}\text { ( } P=\text { potential entrepreneur; } N=N e w \text { enterprise, } G=\text { enterprise in Growth period } \\
M=\text { Mature enterprise) }\end{array}$} & \multirow[b]{2}{*}{ Notes } \\
\hline & $\begin{array}{l}\text { Aspects of } \\
\text { regulation causing } \\
\text { barriers to start- } \\
\text { up/growth of } \\
\text { enterprise }\end{array}$ & $\begin{array}{l}\text { Structuring and } \\
\text { providing } \\
\text { incentives for } \\
\text { investment in } \\
\text { MSMEs }\end{array}$ & $\begin{array}{l}\text { Lack of access to } \\
\text { business finance } \\
\text { and financing } \\
\text { options }\end{array}$ & $\begin{array}{l}\text { Lack of } \\
\text { support and } \\
\text { guidance for } \\
\text { MSMEs }\end{array}$ & \\
\hline Australia & $P, N, G$ & $P, N, G$ & $\begin{array}{l}\text { Access and options } \\
(P, N, G, M)\end{array}$ & $P, N, G, M$ & \\
\hline Brazil & $P, N, G, M$ & $\mathrm{P}, \mathrm{N}$ & $\begin{array}{l}\text { Access and options } \\
(\mathrm{P}, \mathrm{N}, \mathrm{G}, \mathrm{M})\end{array}$ & no & $\begin{array}{l}\text { Notable difference in } \\
\text { challenges by sector (see } \\
\text { questionnaire) }\end{array}$ \\
\hline Chile & $P, N, G$ & $\mathrm{P}, \mathrm{N}$ & $\begin{array}{l}\text { Access }(P, N, G) \\
\text { Options }(N, G, M) \text {, }\end{array}$ & $\mathrm{N}, \mathrm{G}, \mathrm{M}$ & $\begin{array}{l}\text { There is also a notable } \\
\text { gender gap across all } \\
\text { stages. This is being } \\
\text { addressed }\end{array}$ \\
\hline China & $\mathrm{P}, \mathrm{N}$ & $\mathrm{P}, \mathrm{N}$ & $\begin{array}{l}\text { Access and options } \\
(P, N, G)\end{array}$ & $\mathrm{P}, \mathrm{N}$ & \\
\hline Colombia & $\mathrm{P}, \mathrm{N}, \mathrm{G}$ & $\mathrm{N}, \mathrm{G}, \mathrm{M}$ & $\begin{array}{l}\text { Access }(P, N) \text { and } \\
\text { options }(P, N, M)\end{array}$ & $\mathrm{N}, \mathrm{G}, \mathrm{M}$ & \\
\hline Denmark & $P, N, G, M$ & $P, N, G, M$ & $\begin{array}{l}\text { Access }(P, N, G, M) \\
\text { options }(P, N, G, M)\end{array}$ & no & $\begin{array}{l}\text { Various programmes are } \\
\text { underway to address the } \\
\text { challenges faced by } \\
\text { enterprises in Denmark }\end{array}$ \\
\hline Estonia & no & $P, N, G$ & $\begin{array}{l}\text { Access and options } \\
(\mathrm{P}, \mathrm{G})\end{array}$ & $\mathrm{G}$ & $\begin{array}{l}\text { In Estonia MSMEs appear } \\
\text { to reach a 'glass ceiling' at } \\
1 \text { million EUR and do not } \\
\text { have the skills to continue } \\
\text { to grow }\end{array}$ \\
\hline India & $P, N, G$ & $P, N, G$ & $\begin{array}{l}\text { Access }(P) \text { and } \\
\text { options }(P, N, G)\end{array}$ & $P, N, G$ & \\
\hline Indonesia & $P, N, G, M$ & $P, N, G, M$ & $\begin{array}{l}\text { Access and options } \\
(\mathrm{P}, \mathrm{N}, \mathrm{G}, \mathrm{M})\end{array}$ & $P, N, G, M$ & $\begin{array}{l}\text { Indonesia is actively } \\
\text { tackling these issues } \\
\text { through various acts, } \\
\text { strategies and initiatives }\end{array}$ \\
\hline Italy & $\mathrm{P}, \mathrm{N}$ & $\mathrm{N}, \mathrm{G}$ & $\begin{array}{l}\text { Access (N, G) and } \\
\text { options }(P, N, G, M)\end{array}$ & $\mathrm{P}$ & \\
\hline Jamaica & no & $P, N, G$ & $\begin{array}{l}\text { Access and options } \\
(\mathrm{P}, \mathrm{N})\end{array}$ & $P, N, G, M$ & \\
\hline Japan & & $P, N, G, M$ & $\begin{array}{l}\text { Access }(P, N, G) \\
\text { and options }(P, N, \\
G, M)\end{array}$ & $P, N, G, M$ & $\begin{array}{l}\text { Japan Revitalization } \\
\text { Strategy (2015 version) } \\
\text { notes "raise the current } \\
\text { business start-up rate" as } \\
\text { one of the goals to be } \\
\text { achieved }\end{array}$ \\
\hline Romania & $\mathrm{P}, \mathrm{N}$ & $\mathrm{P}, \mathrm{N}$ & $\begin{array}{l}\text { Access and options } \\
(P, N, G)\end{array}$ & $P, N, G, M$ & \\
\hline Serbia & $P, N, G, M$ & $P, N, G$ & $\begin{array}{l}\text { Access and options } \\
(\mathrm{P}, \mathrm{N}, \mathrm{G}, \mathrm{M})\end{array}$ & $P, N, G$ & \\
\hline Spain & $P, N, G, M$ & no & Access $(P, N, G, M)$ & $P, N, G, M$ & Data are available \\
\hline Turkey & $\mathrm{N}, \mathrm{G}, \mathrm{M}$ & $P, N, G, M$ & $\begin{array}{l}\text { Access and options } \\
(P, N, G, M)\end{array}$ & & $\begin{array}{l}\text { Source: SME Strategy } \\
\text { and action plan 2015- } \\
\text { 2018. Other weaknesses } \\
\text { identified }\end{array}$ \\
\hline
\end{tabular}

Responses to stocktake. Responding countries not listed had limited or no information for this section; similarly empty cells indicate that the information was not available. 
In some countries and economies, entrepreneurs and newly established MSMEs may face difficulties opening bank accounts and accessing financial services.

Access to finance to start or grow a business is often considered to be one of the main barriers to entrepreneurship and small business development, in terms of both the availability of external sources of financing, and the conditions applying to such financing (interest rates, fees, tenure, collateral required, other terms and conditions applied to MSME financing) (see Box 2 for an overview of sources of finance).

The OECD/INFE stocktake indicated that general financial exclusion itself (i.e. lack of access to appropriate financial products) creates difficulties for entrepreneurs in some countries. Responses to the stocktake indicate that financial exclusion among individuals ${ }^{4}$ is a barrier for potential entrepreneurs (China, Colombia) and/or new enterprises (Brazil, Chile, Indonesia, Jamaica). Respondents in Serbia and Turkey noted that exclusion affects enterprises throughout the life course.

However, lack of access to formal sources of finance for MSMEs is not necessarily a result of low levels of consumer financial inclusion. Difficulties accessing finance are commonplace in most responding countries and the options for financing appear to be limited. Many countries have indicated that enterprises at all stages are impacted by these issues, although, in some, including Chile, India and Italy mature companies no longer face issues with access. Several country responses also indicate that awareness and knowledge of the financial options available to MSMEs create challenges across enterprises at different stages (Chile, Colombia, Estonia and Japan among others).

When seeking external financing (as opposed to using retained earnings or sales of assets) evidence suggests that MSMEs and potential entrepreneurs rely heavily on traditional bank lending and may tend to approach their local bank, with which they already have a relationship, for financing. Such local 'relationship' banks have the infrastructure and know-how that allows them to deal with the fixed-cost nature of small loan origination, sourcing, monitoring and credit analysis (Nassr and Wehinger, 2015a). They also have a good understanding of the specificities of the local market and the networks/capacity to reach out to small local companies at the local level. In emerging markets, banks act as a bridge to informal MSMEs and can play a key role in connecting them with the formal economy and the markets. However, as banking operations become more centralised, bank branches have less autonomy to assess documentation and make decisions about whether to provide credit, thus negating the potential benefits of local knowledge and networks.

In the aftermath of the Great Recession, the quantity and distribution of credit has reduced in many countries. The effects of this have been felt particularly strongly by MSMEs. As they are more reliant on traditional bank lending, bank deleveraging and adjustments to the regulatory framework of banks can create serious financial constraints for MSMEs (Figure 4) (OECD, 2017b). In addition, borrowing conditions tend to be stricter for MSMEs than for larger enterprises, as evidenced by the positive interest rate spread between the interest rate applied to large company loans and the one applied to small business loans in a large number of jurisdictions (Table 4) (OECD, 2017b).

4. Financial exclusion refers to difficulty in accessing basic financial products and services such as transaction accounts or insurance products. 
Figure 4. Trends in outstanding SME loans, 2013 and 2015

Relative to 2010 , percentages $(2010=0)$

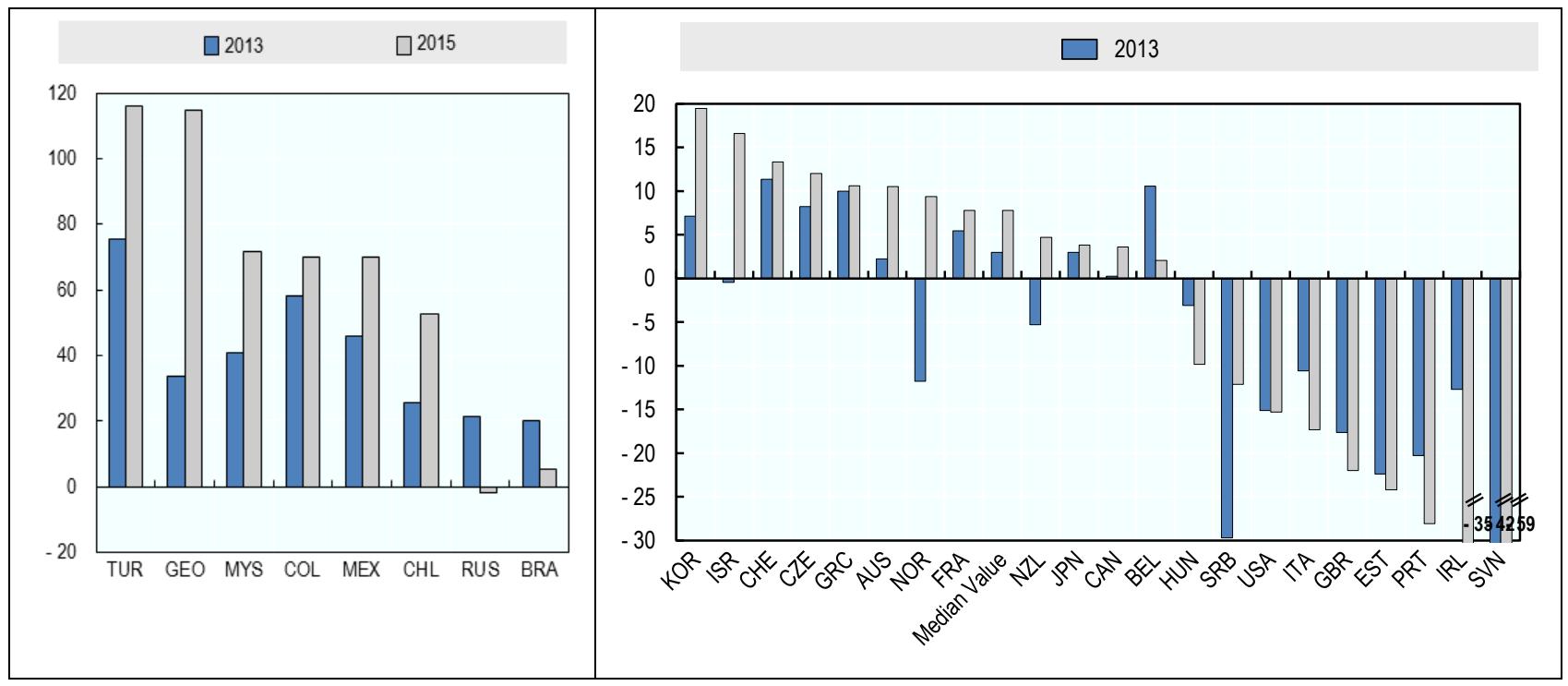

Source: OECD (2017c) http://dx.doi.org/10.1787/fin sme ent-2017-en 
Table 4. Interest rate spreads between loans to SMEs and to large enterprises, 2007-15

In percentage points

\begin{tabular}{|c|c|c|c|c|c|c|c|c|c|}
\hline & 2007 & 2008 & 2009 & 2010 & 2011 & 2012 & 2013 & 2014 & 2015 \\
\hline Australia & 0.96 & 1.83 & 1.71 & 1.62 & 1.57 & 1.78 & 2.15 & 2.03 & 1.99 \\
\hline Austria & 0.42 & 0.43 & 0.56 & 0.47 & 0.37 & 0.48 & 0.51 & 0.53 & 0.41 \\
\hline Belgium & 0.73 & 0.65 & 0.92 & 0.81 & 0.66 & 0.58 & 0.3 & 0.32 & 0.23 \\
\hline Brazil & .. &.. &.. &.. &.. & 8.03 & 7.7 & 10.3 & 14.85 \\
\hline Canada & 1.4 & .. & 3.1 & 3.2 & 2.3 & 2.4 & 2.6 & 2.1 & 2.3 \\
\hline Chile & .. & .. &.. & 6.51 & 6.64 & 6.99 & 7.13 & 6.32 & 5.49 \\
\hline China & .. & .. & .. & .. & .. & .. & 0.67 & 0.04 & -0.03 \\
\hline Colombia & 7.56 & 8.89 & 10.34 & 11.43 & 5.06 & 5.43 & 5.26 & 5.21 & 5.91 \\
\hline $\begin{array}{l}\text { Czech } \\
\text { Republic }\end{array}$ & 0.98 & 0.73 & 1.18 & 0.67 & 1.1 & 1.05 & 1.24 & 1.76 & 0.9 \\
\hline Denmark & 0.73 & 0.36 & 0.75 & 0.9 & 0.86 & 1.03 & 1.27 & 1.92 & 1.53 \\
\hline Estonia & 0.4 & 0.67 & 1.11 & 1.14 & 1.13 & 0.96 & 0.57 & 0.63 & 0.68 \\
\hline Finland & 0.56 & 0.5 & 0.78 & 0.8 & 0.64 & 0.79 & 0.9 & 1.02 & 1.5 \\
\hline France & 0.58 & 0.66 & 0.91 & 0.91 & 0.89 & 0.71 & 0.7 & 0.78 & 0.59 \\
\hline Georgia & .. & & .. & 2.89 & 1.4 & 1.68 & 0.37 & 0.69 & 1.4 \\
\hline Greece & 1.25 & 1.11 & 1.1 & 1.26 & 1.03 & 0.95 & 0.74 & 0.25 & 0.56 \\
\hline Hungary & 1.22 & 0.97 & 1.24 & 1.74 & 1.3 & 3.2 & 3.1 & 2.7 & 2.4 \\
\hline Ireland & 0.28 & 0.48 & 0.76 & 1.02 & 1.35 & 1.53 & 1.54 & 1.8 & 2.34 \\
\hline Israel & .. & .. & .. & 2 & 2.45 & 1.9 & 1.44 & 1.35 & 1.19 \\
\hline Italy & 0.6 & 1.4 & 1.4 & 1.5 & 1.7 & 1.8 & 2 & 1.8 & 1.78 \\
\hline Korea & 0.76 & 0.79 & 0.56 & 0.54 & 0.55 & 0.43 & 0.24 & 0.18 & 0.16 \\
\hline Luxembourg & 0.54 & 0.75 & 0.21 & 0.41 & 0.06 & 0.35 & 0.41 & 0.61 & 0.47 \\
\hline Malaysia & .. & 0.31 & 0.42 & 0.69 & 0.82 & 0.94 & 2.3 & 2.04 & 3.04 \\
\hline Mexico $^{1}$ & .. & .. & 3.75 & 3.78 & 3.57 & 3.45 & 3.24 & 3.1 & 3.08 \\
\hline Netherlands & .. & .. & .. & .. & 2.9 & 1.5 & 0.9 & 1.3 & 2 \\
\hline New Zealand & 3.15 & 2.96 & 4.12 & 3.82 & 3.97 & 3.54 & 4.15 & 4.31 & 4.03 \\
\hline Portugal & 1.76 & 1.72 & 1.87 & 2.25 & 2.01 & 2.16 & 1.85 & 1.6 & 1.35 \\
\hline Russia & .. & .. & .. & .. & .. & .. & .. & 3.15 & 3.49 \\
\hline Serbia & 4.37 & 2.85 & 3.35 & 2.7 & 1.85 & 1.39 & 1.61 & 2.17 & 2.09 \\
\hline $\begin{array}{l}\text { Slovak } \\
\text { Republic }\end{array}$ & .. & .. &.. & $\cdot$. & .. & 1.9 & 1.8 & 1.8 & .. \\
\hline Slovenia & 0.31 & 0.31 & 0.22 & 0.02 & 0.02 & -0.21 & -0.08 & 0.54 & 0.42 \\
\hline Spain & 0.63 & 1.21 & 1.47 & 1.21 & 1.59 & 2.3 & 2.1 & 1.87 & 1.04 \\
\hline Sweden & 0.87 & 0.82 & 0.72 & 0.95 & 1.16 & 1.04 & 0.65 & 0.56 & 0.4 \\
\hline Switzerland & .. & .. & 0.86 & 0.88 & 0.92 & 0.9 & 0.83 & 0.89 & 0.91 \\
\hline Thailand & 1.2 & 1.31 & 1.42 & .. & 2.65 & 1.5 & 1.3 & .. & .. \\
\hline $\begin{array}{l}\text { United } \\
\text { Kingdom }\end{array}$ & .. & 1.05 & 1.12 & 1.39 & 1.27 & 1.31 & 1.4 & 0.97 & 1.22 \\
\hline United States & 1.37 & 1.52 & 1.59 & 1.63 & 1.64 & 1.77 & 1.62 & 1.36 & 1.39 \\
\hline $\begin{array}{l}\text { Median } \\
\text { Value }\end{array}$ & 0.81 & 0.82 & 1.12 & 1.24 & 1.33 & 1.5 & 1.4 & 1.6 & 1.4 \\
\hline
\end{tabular}

Source: OECD (2017c) http://dx.doi.org/10.1787/fin sme ent-2017-en 
Box 2. Alternative financing and indirect instruments

\begin{tabular}{|c|c|c|c|}
\hline Low Risk/ Retum & Low RiskJ Retum & Medium RiskJ Retum & High RiskJ Return \\
\hline Asset-Based Finance & Alternative Debt & "Hybrid" Instruments & Equity Instruments \\
\hline $\begin{array}{l}\text { - Asset-based lending } \\
\text { - Factoring } \\
\text { - Purchase Order } \\
\text { Finance } \\
\text { - Warehouse Receipts } \\
\text { - Leasing }\end{array}$ & $\begin{array}{l}\text { - Corporate Bonds } \\
\text { - Securitised Debt } \\
\text { - Covered Bonds } \\
\text { - Private Placements } \\
\text { - Crowdfunding (debt) }\end{array}$ & $\begin{array}{l}\text { - Subordinated } \\
\text { Loans/Bonds } \\
\text { - Silent Participations } \\
\text { - Participating Loans } \\
\text { - Profit Participation } \\
\text { Rights } \\
\text { - Convertible Bonds } \\
\text { - Bonds with Warrants } \\
\text { - Mezzanine Finance }\end{array}$ & $\begin{array}{l}\text { - Private Equity } \\
\text { - Venture Capital } \\
\text { - Business Angels } \\
\text { - Specialised Platforms } \\
\text { for Public Listing of } \\
\text { SMEs } \\
\text { - Crowdfunding (equity) }\end{array}$ \\
\hline
\end{tabular}

Source: OECD (2015c).

\section{Alternative financing}

As credit sources tend to dry up more rapidly for small firms than for large companies during economic downturns, broadening the range of non-bank debt financing instruments for SMEs should help to make them more resilient to financial shocks. Given SMEs' importance in all economies, this is also essential for economic recovery from economic and financial crises.

There is also a need for wider use of the market-based funding by MSMEs, particularly at the current juncture, as a complement to traditional bank lending channels, although the removal of intermediaries ('disintermediation') in SME financing is neither achievable nor necessarily desirable. ${ }^{5}$

Asset-based finance, such as leasing, hire-purchase and factoring, are the most widely-used alternatives to bank lending for the financing of working capital needs, domestic and international trade, and, partly, for investment purposes (OECD, 2015c). The provision of financing on the back of fixed assets (machinery, equipment, inventory), or accounts receivables (factoring) is allowing new and small enterprises to overcome the unavailability of adequate collateral or credit track record.

Venture Capital financing (including business angels) is provided to non-listed MSMEs and to potential start-up entrepreneurs to support their pre-launch, launch and early stage development phases of the business. It is particularly important for young, innovative firms with growth potential but an untested business model or track record.

\section{Indirect instruments}

On the debt side, high-quality securitisation of MSME loans and other liabilities (such as leasing) can act as a market-based shortcut to indirectly promote MSME financing, without the complete disintermediation of banks. Transferring MSME credit risk partially from originators to institutional and long-term investors through the pooling of MSME liabilities by an originator (typically a bank) creates headroom in banks' balance sheets and allows them to further on-lend to small heterogeneous and mostly local MSMEs. Through various forms of credit enhancement (e.g., government guarantees), non-investment grade parts of SME loan portfolios can be transformed into investment grade instruments. Institutional and long-term investors can indirectly finance MSMEs by investing in securitisation products, while at the same time banks continue to originate the bulk of small loans, leveraging on their expertise, infrastructure and local presence (Nassr and Wehinger, 2015a).

Similar to securitisation, MSME covered bonds are asset-backed debt instruments secured by a priority claim on SME high-quality assets which remain on the lender's balance sheet. Covered bonds offer an alternative cost-effective form of wholesale funding which remains resilient even in times of crisis, as well as investor diversification. In Europe, a long history of the instrument in the market combined with a favourable eligibility treatment in the context of ECB's (and other central banks') operations has further encouraged issuance levels.

The potential role of market-based financing for SMEs has also been recognised by the G20 (OECD, 2015a). 


\section{Box 2. Alternative financing and indirect instruments (cont.)}

Although securitisation and covered bonds have an important role to spear-head SME financing, they are indirect MSME financing instruments enabling banks and institutional investors to channel funds to MSMEs in an efficient and simple way (OECD, 2015a). There is therefore little direct impact of financial literacy levels of the MSMEs themselves on securitisation and covered bond issuance levels.

Small-cap bonds, mini-bonds and private placements are directly issued by small companies and placed with investors. A number of specialised retail bond markets for smaller companies have been established in recent years, mostly in Europe. Despite simpler processes, more flexible requirements and waiving of the relevant costs offered to small companies, these debt instruments remain marginal. Low levels of bond issuance can be partly attributed to the structural disadvantages arising mainly from limitations inherent to the small size and heterogeneous nature of MSMEs. Such limitations undermine the profitability of transactions for the issuer, and together with the absence of credit ratings by the smaller MSMEs, impede their accessibility by the micro and smaller-size MSMEs (Nassr and Wehinger, 2014).

Whilst many governments have incentives in place to encourage start-ups and create growth, incentivising investment in such businesses is still considered to be a challenge in many of the countries responding to the stocktake; suggesting that investors are not easily persuaded to put their money into smaller enterprises. As may be expected, the challenge is greatest in terms of encouraging investment in potential entrepreneurs, but even in the growth phase, it is still seen as problematic in Australia, Colombia, Denmark, Estonia, India, Indonesia, Italy, Jamaica, Serbia and Turkey, showing a widespread issue.

This is also evidenced by OECD data showing that post-crisis levels of investment in the venture capital industry have not recovered (Figure 5), although seed and start-up stage financing holds up better than later-stage financing. As shown in Figure 6, with the exception of the United States and Israel, venture capital represents a very small percentage of GDP, and the average investment per company has declined compared to the pre-crisis level (OECD, 2015b).

Figure 5. Trends in venture capital investments

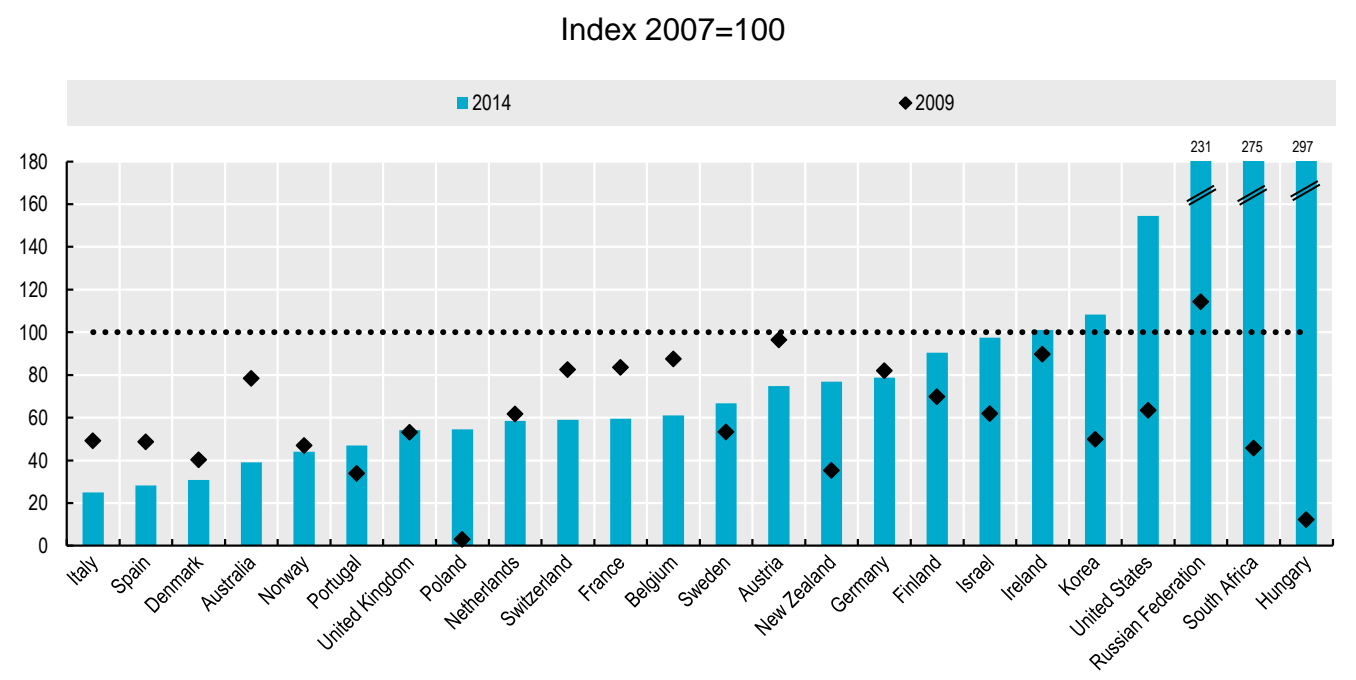

Source: OECD (2015b) http://dx.doi.org/10.1787/entrepreneur aag-2015-en. 
Figure 6. Venture capital investments as a percentage of GDP

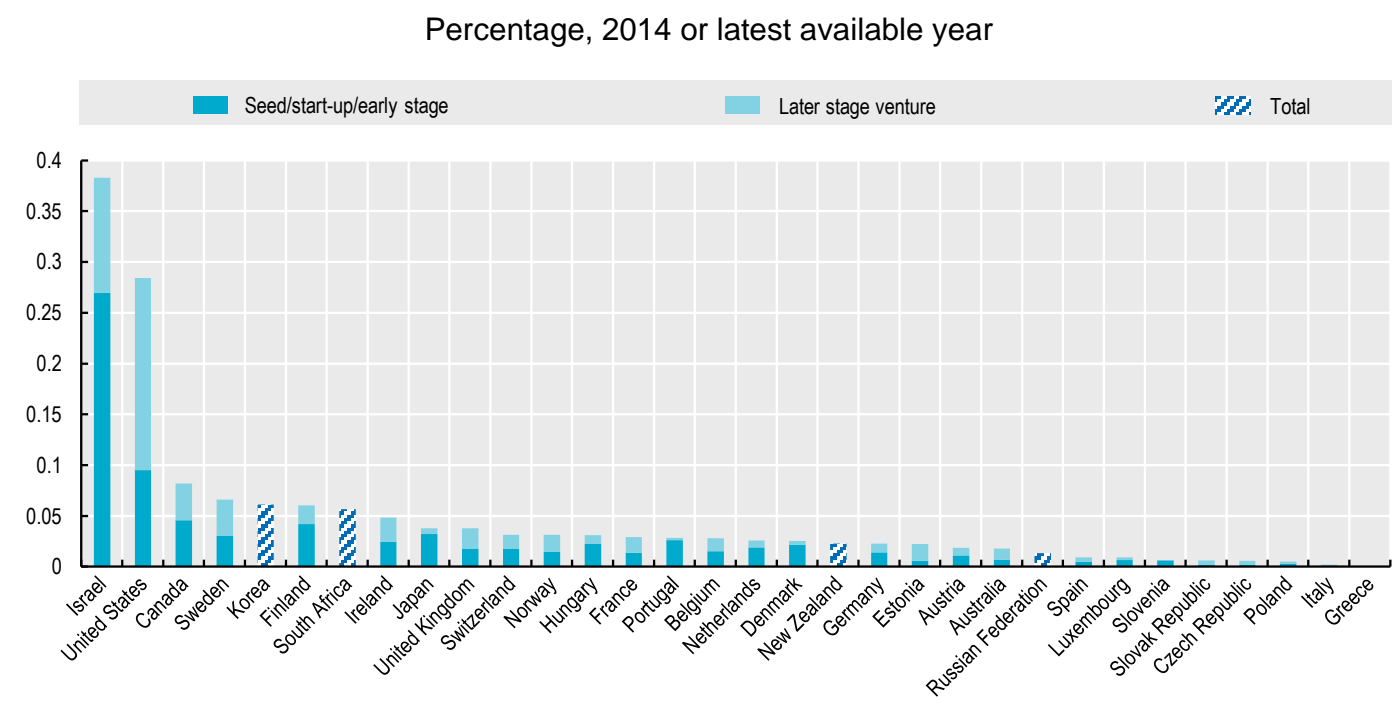

Source: OECD (2015b) http://dx.doi.org/10.1787/entrepreneur aag-2015-en.

Some countries report that there are plans to change incentive mechanisms and make it easier for companies to access newer forms of financing such as crowd-sourced funding (Australia and Estonia) or the support of business angels (Estonia). In Denmark, there is a Business Forum for Simpler Rules in order to reduce the administrative burden and cost of compliance, and a government investment fund created in 1992 (the Growth Fund) to provide access to finance for MSMEs and improve their awareness and understanding of financing options.

Indeed, the emergence of FinTech ${ }^{6}$ platforms such as peer-to-peer (P2P) origination platforms for small business lending and crowdfunding platforms could fill part of the MSME financing gap left by traditional banks in the post-crisis era. In developed economies, marketplace lending can provide a lower cost - higher efficiency service than traditional banks, enabling such platforms to compete with incumbents for MSMEs funding on the basis of cost. In emerging economies, where availability of credit is a more pressing issue, P2P lenders offer availability of credit, speed and digital outreach that allows them to lend to the underserviced MSMEs and the underbanked more broadly.

Increasing institutional investor participation in such platforms can boost the scale of origination and growth of the market beyond the retail level. The importance of data, integrated content and analyticsrelated FinTech for credit scoring could ultimately define the extent of potential disintermediation of traditional financial institutions (OECD, 2017 forthcoming). But although an increasingly large part of the funding is being provided by institutional investors, consumer and investor protection risks remain high and cases of fraud have already been reported. While promising for MSME and the underbanked, FinTech innovations therefore clearly introduce vulnerabilities that could ultimately undermine customer confidence and trust (see Box 3 for further discussion of FinTech).

$6 \quad$ Financial technology or "FinTech" defined here as emerging innovation involving the use of technology for the provision of financial services. It includes, inter alia, digital banking, innovation in digital payments, P2P currency exchanges, lending platforms, data analytics related to the provision of financial services and roboadvising. 


\section{Box 3. Financial education and FinTech: The case of marketplace lending and crowdfunding}

FinTech platforms such as peer-to-peer (P2P) origination platforms for small business lending and crowdfunding platforms can offer financial services to the underbanked and underserviced MSMEs in advanced and emerging economies, potentially filling part of the MSME financing gap.

The business models of such platforms vary significantly, partly as a result of the lack of regulation. There are broadly three main types of platforms catering to MSME funding: (i) pure intermediation platforms, connecting lenders and borrowers and providing information transparency about the borrower, (ii) platforms running asset pools (bank-like model), whereby lending funds and loans are pooled without proper allocation of which lender is lending to which borrower, and (iii) equity crowdfunding, in which entrepreneurs raise money in exchange for a percentage of equity (shares) in the company.

The absence of capital requirements and/or financial regulation in some cases has allowed for the rapid expansion of marketplace lending but involves important systemic risks as the resilience of new platforms in credit cycles remains untested. Origination practices in the absence of "skin in the game" (personal investment from the platform owners) could be compromised, which could in turn give rise to systemic risks as marketplace lending becomes increasingly connected to the rest of the system (e.g. funding by institutional investors, securitisation of marketplace lending portfolios, listings).

This was the case in the largest P2P lending market in the world, China, where the lack of regulation has resulted in high failure rate and fraud rate. In 2016, one of the largest P2P lenders, Ezubao, defaulted on its investors amounting USD 7.6 billion. Allegations over a 'Ponzi' scheme involved the use of the platform to create fictitious borrowers and the sale of such fictitious loans to investors, mainly retail individuals. Other cases of fraud have occurred in this space, with reportedly over 500 problematic platforms identified where there has been fraud, the owner has ran away, lost contact, closed down, or had experienced problems with withdrawal of funds.

Although increased regulatory scrutiny will address part of the consumer and investor protection issues, there is a clear case for more and better financial education for MSMEs using FinTech platforms to raise financing. Increased financial literacy can allow MSMEs to take advantage of the opportunities for alternative (and cheaper in many cases) funding, while at the same time being aware of the risks involved in the use of such platforms, their real costs and their limitations. The allocation of liability in case of flaws or malfunctioning of the platform, consumer protection issues around fraud or platform failure are only some of the potential risks that need to be understood by the user of the platform. Issues around the use of data and data ownership when it comes to the financial information of the company are also important considerations.

The role of financial education is double, covering both the receiving end of the financing (the MSME as a borrower) but also the supplier side (the investor as the provider of funding, and especially the retail investor). There is a need for investors to have sufficient financial literacy skills to understand the risks involved in being on the borrower's side in such funding. This is particularly relevant for equity crowdfunding, where investors are faced with an information asymmetry between themselves and the entrepreneur. Retail investors may lack the experience of participating in equity offerings, may not have the skills required to evaluate the project and perform a due diligence or the understanding of the shareholder terms and illiquidity of their investment. To that end, the International Organization of Securities Commissions (IOSCO) has recently noted that regulators and policymakers should consider including special provisions "requiring investor education and/or statements signed by investors acknowledging their understanding of risks" in order to address such risks (IOSCO, 2016).

A large part of public support schemes for MSMEs and potential entrepreneurs is focused on the provision of financing in preferential terms, in order to address market failures in MSMEs' access to financing for the launch or development of their businesses. These schemes do not always enjoy high take-up. This can result from a range of factors, including low demand and impaired financial transmission of credit, but also to the lack of awareness among micro-enterprises about the existence of such schemes (OECD, 2015a). 


\section{Knowledge, skills and confidence of entrepreneurs}

Whilst the business landscape can create a macro environment that supports or inhibits the creation and growth of enterprises the individual characteristics of the population of potential entrepreneurs and business owners also create micro level challenges and opportunities. Entrepreneurs need to know how to make the best use of their resources and navigate through any challenges they may face, drawing on financial literacy, entrepreneurial skills and business knowhow.

\section{Entrepreneurial skills and business knowhow}

It is possible for policy makers to remove the barriers to entry for MSMEs by addressing regulatory burden modernising tax frameworks, and increasing access to finance, but potential entrepreneurs still need confidence and possibly encouragement to take the first steps towards creating their business and more experienced ones need a sound foundation set of entrepreneurial skills. Entrepreneurial training has the potential to significantly increase the number of healthy enterprises and improve their efficiency. Information and guidance could facilitate MSME's compliance with tax and regulation requirements, and minimise the compliance burden around complex tax, insurance and pension issues. At the same time, adequate guidance has the potential to encourage MSMEs into the formal economy and improve overall compliance levels of MSMEs.

Lack of general entrepreneurial skills are considered to be a challenge across the various stages of an enterprise in some countries such as Denmark, where this is being addressed through access to business education and sector specific skills. Elsewhere (e.g. Australia, China, Spain), entrepreneurial skills are only considered to be of issue for potential entrepreneurs, possibly reflecting the need to encourage entrepreneurial skills among a greater number of individuals in those countries.

The stocktake indicates a need for more tailored support and guidance for MSMEs in many of the responding countries, although this is not considered to be a particular issue in a few countries such as Brazil and Denmark (Table 5). In Australia, for example, feedback indicates that it is possible for MSMEs to access information but much harder to access more formal education modules designed to support small businesses. In Estonia, the guidance and support that exists is primarily designed to teach facts, which can provide a useful foundation level of knowledge, but there is less help to enterprises through the growth stage, when they need to develop creative and social skills and encourage team-working.

Data on access of adults to training on starting a business either during or after school across 38 countries indicates that the proportion of adults having received such training varies widely across countries (fewer than $8 \%$ of adults in the Dominican Republic, Egypt and Romania reported having access to any such training compared with over $40 \%$ in Chile and Finland) but typically remains low (Global Entrepreneurship Monitor, 2008).

\section{General and specific business skills}

MSMEs need a wide range of skills, including the skills that will enable them to effectively negotiate and operate within a business environment, the ability to manage a business and other people and the sector specific skills that can help them to succeed in even competitive and volatile environments. In Estonia, research indicates that there is a lack of management skill and business acumen among growing and mature enterprises (Global Entrepreneurship Monitor, 2015).

The needs of MSMEs vary according to the life stage of the enterprise. In Brazil and Chile for example, it is recognised that lack of management skills are a problem for potential and newly established businesses, whilst in Brazil lack of knowledge on financing options remains a problem through to maturity and in Chile knowledge of exporting procedures is considered weak at all stages of business. In Romania, 
management skills are not considered to be an issue as managers are generally well educated but general entrepreneurial and sector specific skills are lacking in some enterprises; in particular, there is concern about this within the agricultural sector and rural economy in general.

Recent analysis in Turkey shows that there are many skills deficits among MSMEs. These include (but are not limited to) management skills such as the ability and willingness to hire suitable staff and accept new partners, a lack of skills related to marketing, public relations, trademarks, and a failure to produce high-value products and benefit from economies of scale (see Box 4 for further information).

The challenge of developing sector-specific skills has been highlighted in several countries. This again suggests that enterprises are being created as a result of a lack of alternative forms of employment, rather than from a strong entrepreneurial drive. In several countries, the concern remains even during the growth and/or maturity phases of firms (e.g. Australia, Chile, Colombia, Italy, Jamaica, Japan, Romania, Serbia).

\section{Awareness of financing options}

One of the major impediments to the use of alternative financing instruments by MSMEs is that most of them are unaware or ill-informed about the possibilities to finance themselves through such channels. Even those MSMEs who are aware of alternative financing options, find themselves reluctant to tap them due to misconceptions or lack of confidence. MSMEs need to have a reasonable level of knowledge about the possibilities available to them, and the skills and confidence necessary to tap market-based financing (OECD, 2015a). Besides being better-aware of the financing channels available, financial education can help MSMEs assess the appropriateness and suitability of equity vs. debt finance for their business model, evaluate the terms and conditions applying to the proposed instruments and respond to market and investor requirements throughout the life of the financing.

Public equity platforms for small companies are a good illustration of the above, with the financial literacy gap of MSMEs with regard to equity financing limiting their access to such instruments (Figure 7; Nassr and Wehinger, 2015b). Bridging this gap through the provision of financial education for MSMEs has been identified by both the public and private sector as a pre-requisite for the wider use of public equity platforms by small companies (see also box 6). 
Figure 7. Small company equity listings, Global 2000- Q1 2015

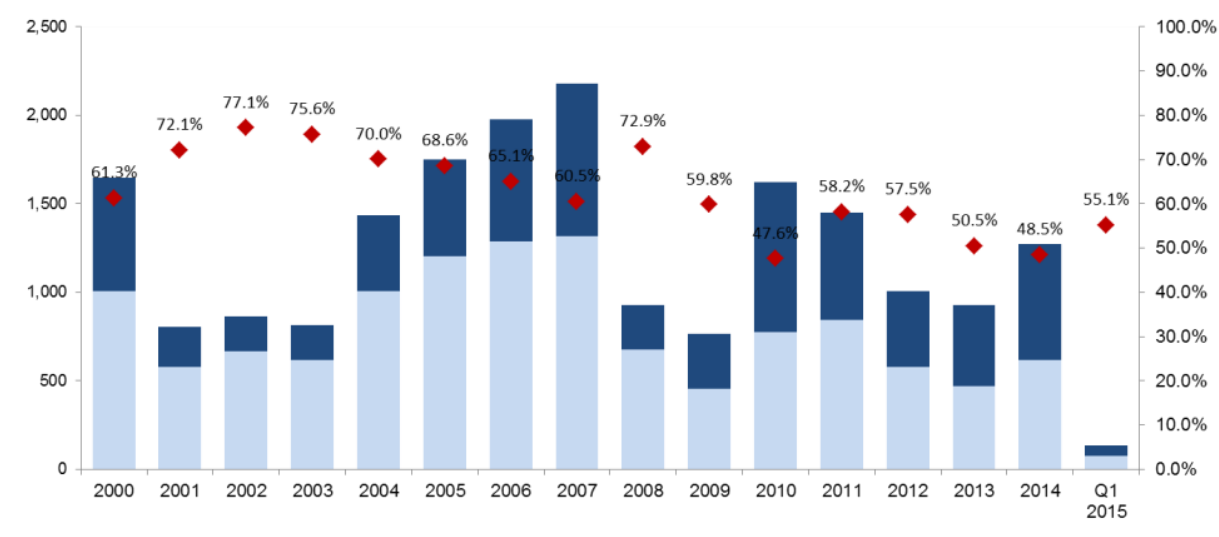

Small IPOs (in absolute number of IPOs) — Large IPOs (in absolute number of IPOs) • Small IPOs (\% out of total number of IPOs)

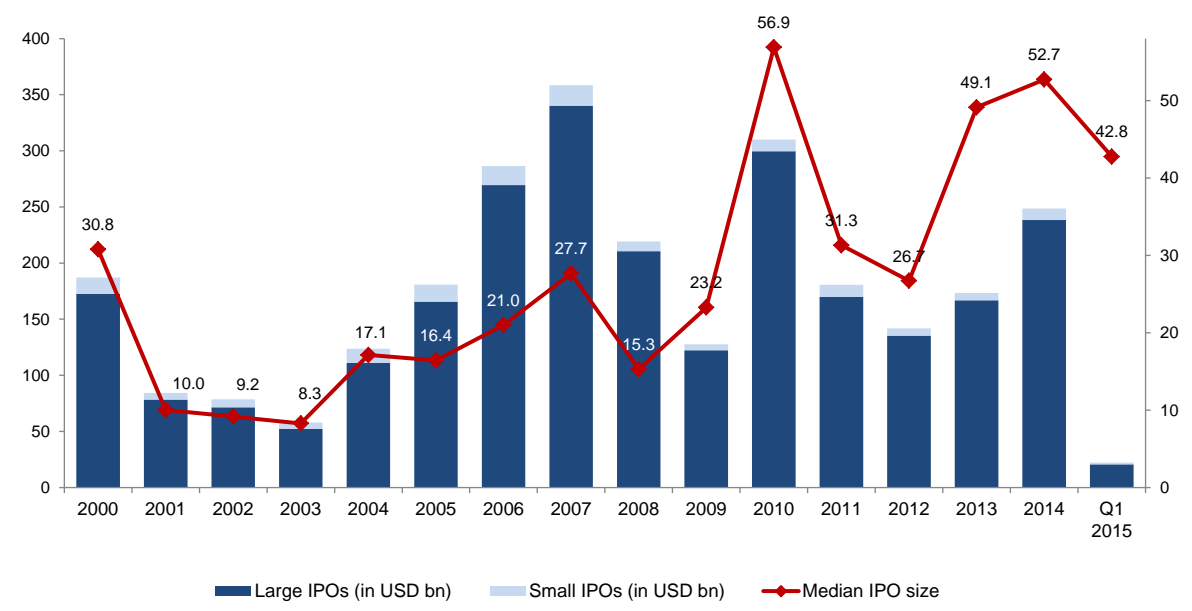

Source: OECD (2015a), Nassr and Wehinger (2015b)

\section{Financial literacy}

A lack of individual financial literacy is thought to affect potential entrepreneurs in most of the countries responding to the stocktake questionnaire (Table 6). This is consistent with other findings suggesting that low levels of financial literacy augment difficulties accessing finance in the early stages of business creation. Low levels of financial literacy can also hinder the sustainability and growth of a business, which could be a problem in countries such as Australia, Brazil, Chile, Estonia, India, Indonesia and Serbia which report low levels of financial literacy among businesses in the growth phase. Conversely, in China, Colombia, Jamaica, Japan and Romania financial literacy is not considered to be the most pressing issue for enterprises in the growth and mature phases, perhaps indicating that improving the levels of financial literacy can ease barriers to entry; or that financial literacy levels improve as businesses grow.

Better financial literacy levels can empower MSMEs and potential entrepreneurs with knowledge about possible sources of finance including public funding schemes, and skills that will allow them to weigh their options, successfully seek financing and optimise their financial structure (Figure 8). They will also help MSMEs to avoid the potential pitfalls of new delivery methods such as FinTech and identify potential theft and fraud (OECD/INFE, 2017). 
In contrast, potential entrepreneurs and MSMEs with low levels of financial literacy are likely to find it difficult to make decisions about appropriate sources of funding and may find themselves ill-equipped to respond to the due diligence requirements of potential sources of finance or negotiate the terms and structuring of the private participation/financing. Furthermore, entrepreneurs who fail to keep proper financial records, and those who do not provide transparent and standardised financial statements and information make it difficult for lenders to assess the intrinsic risk of their company, irrespective of size. This is particularly important in the absence of a formal credit rating.

The role of financial literacy is paramount when it comes to accessing finance, for a number of reasons:

- Well-informed MSMEs can potentially reduce market failures that are due to asymmetries of information between provider and receiver of financing. Such asymmetries of information are a typical characteristic of credit markets that leads to adverse selection (because one side has more information than the other) and moral hazard (because one side has incentives to take unacceptable risk or mislead the other) (Stiglitz et al., 1981; Miller, 2003).

- Better financial analysis and reporting capabilities will improve the ways in which MSMEs describe their financial profile to their creditors during the loan application process, improving their chances of success.

- More financially literate MSMEs are more likely to understand the importance of servicing their loan without missing interest/capital payments or breaking covenants, ${ }^{7}$ and have the skills to make this possible. Cash-flow analysis and projections as well as understanding basic financial ratios are essential for the monitoring of covenants that are often included in loan documentation, as well as for the standard monitoring of the borrower by the bank.

Financial literacy is also important for micro-enterprises tempted to borrow against personal assets, such as their home/real estate property, as collateral, without fully understanding the risks they are taking. Similarly, small business owners relying on personal credit cards, overdrafts, personal secured bank loans or microfinance to fund their projects also need basic levels of financial literacy to identify the potential consequences for their business and household and weigh up the risks and benefits of such an approach.

7 A covenant describes the lender's expectations of the borrower in terms of financial behaviour such as maintaining liquidity or taking on additional debt. 
Figure 8. Improving financial literacy skills for access to finance throughout the life cycle of MSMEs

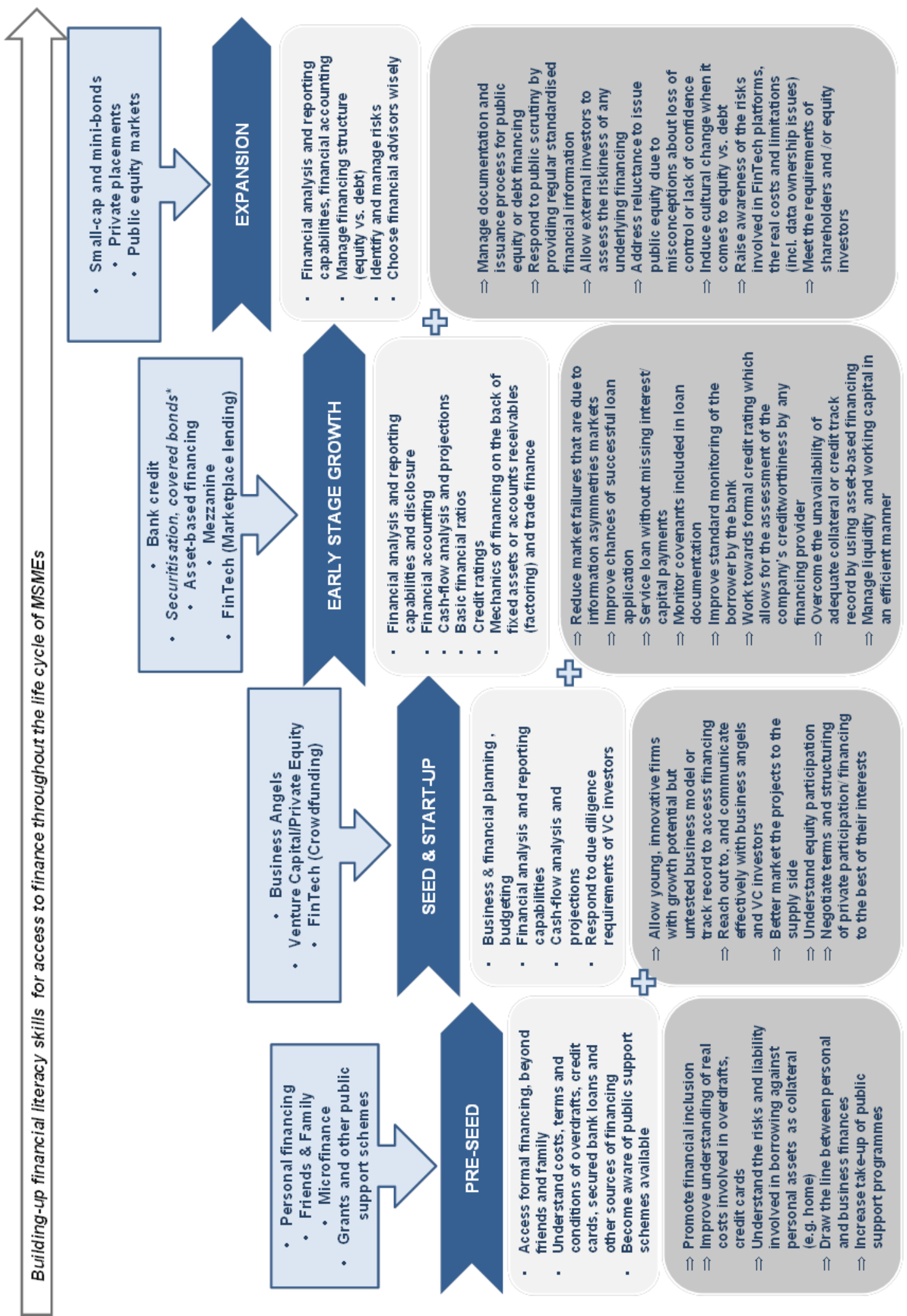

Source: Summary of the life cycle approach of SME financing as described by Berger and Udell (1998). Excluding hybrid financing instruments such as mezzanine, convertible loans, etc. 
Table 5. Challenges faced by MSMEs in terms of skills and experiences of entrepreneurs

\begin{tabular}{|c|c|c|c|c|c|}
\hline \multirow[t]{2}{*}{ Country } & \multicolumn{5}{|c|}{ ( $P=$ potential entrepreneur; $N=$ New enterprise, $G=e n t e r p r i s e$ in Growth period $M=$ Mature enterprise) } \\
\hline & $\begin{array}{l}\text { Lack of } \\
\text { general } \\
\text { entrepreneurial } \\
\text { skills }\end{array}$ & Lack of business skills & $\begin{array}{l}\text { Lack of awareness } \\
\text { of knowledge of } \\
\text { financing options }\end{array}$ & $\begin{array}{l}\text { Lack of } \\
\text { individual } \\
\text { financial } \\
\text { literacy }\end{array}$ & $\begin{array}{l}\text { Financial } \\
\text { exclusion }\end{array}$ \\
\hline Australia & $\mathrm{P}$ & $\begin{array}{l}\text { Business acumen }(P, N) \\
\text { sector-specific }(P, G) \\
\text { management }(P, N)\end{array}$ & $\begin{array}{l}\text { Awareness and } \\
\text { knowledge }(P, N, G)\end{array}$ & $P, N, G$ & $P, N, G$ \\
\hline Brazil & no & $\begin{array}{l}\text { Business acumen }(P) \\
\text { sector-specific }(P, N) \\
\text { management }(P, N)\end{array}$ & $\begin{array}{l}\text { Awareness }(P, N) \text {, } \\
\text { knowledge }(P, N, G \text {, } \\
M)\end{array}$ & $P, N, G$ & $\mathrm{P}, \mathrm{N}$ \\
\hline Chile & $\mathrm{P}, \mathrm{N}$ & $\begin{array}{l}\text { Business acumen }(P, N) \\
\text { sector-specific }(P, N, M) \\
\text { management }(P, N)\end{array}$ & $\begin{array}{l}\text { Awareness }(P, N, G \text {, } \\
M), \text { knowledge }(P, N)\end{array}$ & $P, N, G, M$ & $\mathrm{~N}$ \\
\hline China & $\mathrm{P}$ & $\begin{array}{l}\text { Business acumen }(P, N) \\
\text { sector-specific }(P) \\
\text { management }(P, N)\end{array}$ & $\begin{array}{l}\text { Awareness }(P, N) \text {, } \\
\text { knowledge }(P, N, G)\end{array}$ & $\mathrm{P}, \mathrm{N}$ & $\mathrm{P}$ \\
\hline Colombia & $P, N, G$ & $\begin{array}{l}\text { Business acumen and } \\
\text { sector-specific }(G, M) \\
\text { management }(P, N, G, M)\end{array}$ & $\begin{array}{l}\text { Awareness ( } N, G) \text {, } \\
\text { knowledge }(P, N, G \text {, } \\
M)\end{array}$ & $\mathrm{P}, \mathrm{N}$ & $\mathrm{P}$ \\
\hline Denmark & $P, N, G, M$ & no & no & no & no \\
\hline Estonia & $P, M$ & $\begin{array}{l}\text { Business acumen }(G, M) \\
\text { sector-specific (no) } \\
\text { management }(G, M)\end{array}$ & $\begin{array}{l}\text { Awareness and } \\
\text { knowledge }(P, N, G \text {, } \\
M)\end{array}$ & $P, N, G, M$ & no \\
\hline India & $\mathrm{P}, \mathrm{N}$ & $\begin{array}{l}\text { Business acumen, sector- } \\
\text { specific, and management } \\
(P, N)\end{array}$ & $\begin{array}{l}\text { Awareness and } \\
\text { knowledge }(P, N, G)\end{array}$ & $P, N, G$ & $P, N, G$ \\
\hline Indonesia & & & $\begin{array}{l}\text { Awareness and } \\
\text { knowledge }(P, N)\end{array}$ & $P, N, G, M$ & $\mathrm{P}, \mathrm{N}$ \\
\hline Italy & $P, N, G, M$ & $\begin{array}{l}\text { Sector-specific and } \\
\text { management }(P, N, G, M)\end{array}$ & no & no & no \\
\hline Jamaica & $\mathrm{P}, \mathrm{N}$ & $\begin{array}{l}\text { Business acumen }(P, N), \\
\text { sector specific }(P, N, G, M) \\
\text { and management }(P, N, G)\end{array}$ & $\begin{array}{l}\text { Awareness }(P) \text { and } \\
\text { knowledge }(P, N)\end{array}$ & $\mathrm{P}$ & $\mathrm{P}, \mathrm{N}$ \\
\hline Japan & & $\begin{array}{l}\text { Business acumen }(N, G, M) \text {, } \\
\text { sector specific }(P, N, G) \text { and } \\
\text { management }(P, N, G, M)\end{array}$ & $\begin{array}{l}\text { Awareness and } \\
\text { knowledge }(P, N, G \text {, } \\
M)\end{array}$ & $P, N, G, M$ & \\
\hline Romania & $P, N$ & Sector specific (P, N, G) & $\begin{array}{l}\text { Awareness and } \\
\text { knowledge }(P, N, G)\end{array}$ & $\mathrm{P}, \mathrm{N}$ & no \\
\hline Serbia & $\mathrm{P}, \mathrm{N}$ & $\begin{array}{l}\text { Business and sector } \\
\text { specific }(P, N) \text { management } \\
(P, N, G, M)\end{array}$ & $\begin{array}{l}\text { Awareness }(P, N) \\
\text { knowledge }(P, N, G \text {, } \\
M)\end{array}$ & $P, N, G, M$ & $\underset{M}{P, N, G}$ \\
\hline Spain & $\mathrm{P}$ & no & $\begin{array}{l}\text { Awareness and } \\
\text { knowledge }(P, N, G \text {, } \\
M)\end{array}$ & no & no \\
\hline Turkey & no & $\begin{array}{l}\text { Business acumen and } \\
\text { management skills }(P, N, G \text {, } \\
\text { M) }\end{array}$ & $\begin{array}{l}\text { Awareness (P, N, G, } \\
M)\end{array}$ & no & $\underset{M}{P}, N, G$ \\
\hline
\end{tabular}

Responses to stocktake. Responding countries not listed had limited or no information for this section; similarly empty cells indicate that the information was not available. 


\section{Box 4. Identifying challenges for MSMEs in Turkey}

A recent SWOT analysis conducted while preparing the SME Action Plan 2015-2018 in Turkey identified a wide range of weaknesses that impact on the creation and lifespan of an SME:

\section{Ownership, staff and management issues}

- Unable to solve the problems arising from family-owned company structure

- Lack of professional management and lack of knowledge for management functioning

- Inability to hire and pay qualified work force and improving proportion of women in MSMEs workforce.

- Working inefficiently

\section{Inability to maximise potential and innovate}

- Lack of capacity to prepare projects

- Lack of awareness and knowledge on Research and Development (R\&D), innovation and intellectual property rights

- Inability to commercialize R\&D results, and lack of awareness on the innovation and design

- Unable to benefit from economies of scale

- Lack of PR and marketing skills

- Inability to follow technological developments and innovations

- Lack of optimising capacity

- Competition problems

\section{Lack of financing options and financial literacy}

- Unable to invest in technology due to insufficient capital

- Inability to cash the account receivables.

- Unawareness on the issues related to the energy efficiency

\section{Lack of quality product and reaching relevant markets}

- Limited access to knowledge for researching for international markets

- Lack of producing high value added products

- Inability to institutionalize

- Lack of opportunities to work and to take part in international environment

- Unaware of the importance of building genericized trademarks

\section{Barriers to cooperation and peer learning}

- Lack of cooperativeness and unwillingness to accept new partners

- Lack of cooperation between public/private universities and MSMEs

- Absence of mentorship in relation to relevant investment opportunities

\section{Policy landscape}

- Lack of statistical information on MSMEs.

- Lack of evaluation mechanisms of the MSME programmes.

- Absence of programme evaluation mechanisms of supportive institutions.

- Lack of coordination among the policy makers responsible from MSMEs.

- Unable to educate youth, in line with industrial needs

- Unable to recognize the importance of education on the technical and work related skill.

- Difficulty to reach governments supports

- Unable to follow up public procurements and inability to bid on them. 


\section{Section II. Policy level support for MSMEs}

MSMEs have an important role to play in national economies, but they face numerous challenges, including a lack of appropriate skills, as highlighted in Section I. This section therefore considers the policy responses to the skills deficits faced by MSMEs (see Table 7). In particular it focuses on responses to low levels of financial literacy and related skills and the role of financial education in addressing some of the challenges faced. Since it is more common to develop policy and target initiatives at groups that are definable, this section discusses potential entrepreneurs, as well as micro, small and medium-sized enterprises. The definition of these can be assumed to be based on the criteria highlighted in Table 1, Section I.

\section{Measuring financial literacy levels}

A measure of financial literacy provides policy makers with up-to-date information about the level of knowledge, behaviour and skills in the population of interest. With this empirical evidence policies and programmes can be developed to tackle the challenges identified and targets can be set. Given the benefits of such data, it is not surprising that many countries now routinely measure the financial literacy of their adult population, including through the use of the OECD/INFE measurement tool.

None of the responding countries has a measurement exercise designed to comprehensively measure the financial literacy of MSMEs; Estonia however includes a booster sample in its national financial literacy measure designed to identify entrepreneurs and Colombia has a more general survey of demandside issues among micro-enterprises and others. Other countries have tried to identify entrepreneurs (possibly through information about the work status of respondents) within other datasets, including national financial literacy surveys and household surveys (as in Italy).

As noted in Section I, the financial literacy levels of potential entrepreneurs are a concern to policy makers. As there is relatively little data available for policy makers to rely on, it is quite possible that the levels of financial literacy have been estimated through other means, such as information provided by banks and professionals working with entrepreneurs. It may also be that policy makers are extrapolating from levels of financial literacy among the working population. However, the evidence clearly suggests that a targeted measure of financial literacy that clearly identifies different types of enterprise and potential entrepreneurs could provide valuable additional information that would be beneficial when developing financial education and monitoring overall strategies to support MSMEs. The OECD/INFE will develop a specific measurement tool for this purpose, building on ongoing work to create a core competencies framework for MSMEs.

\section{Targeting MSMEs through National Strategies for Financial Education}

National strategies are tailored approaches to tackling low levels of financial literacy at a national level, and typically include a focus on key target groups considered to be especially vulnerable or important nationally. In some countries, such strategies identify MSMEs as potential recipients of financial education (including Chile, Indonesia, Portugal and Serbia). Elsewhere, comprehensive strategies implicitly aim to reach all sectors of the population (e.g. Australia and Japan) or focus on children in 
schools with the intention of developing necessary skills for young people irrespective of their work life trajectory (as planned in Bangladesh).

Of the countries with comprehensive financial education available, micro-enterprises are the most widely targeted of MSMEs. It is interesting that potential entrepreneurs in Turkey appear to have almost no access to financial education. Small and medium-sized enterprises appear to be well provided-for in some countries, but in Brazil, Chile, Colombia and India medium-sized enterprises are not a key target group for the education on offer.

\section{Targeting MSMEs through other National Frameworks}

Several of the countries responding to the stocktake survey have other frameworks providing some elements of financial education to MSMEs (Table 6). In some countries, such as Chile and Colombia, this falls under a framework for financial inclusion whereas elsewhere specific strategies exist to support entrepreneurs and encourage growth among MSMEs which cover some elements of financial literacy (e.g. Estonia, Indonesia, Japan, Kenya and Serbia).

Table 6. Policy responses to financial education needs

\begin{tabular}{|c|c|c|c|c|}
\hline & $\begin{array}{l}\text { Measure } \\
\text { financial } \\
\text { literacy } \\
\text { of } \\
\text { MSMEs }\end{array}$ & $\begin{array}{l}\text { Addressing } \\
\text { financial } \\
\text { education needs } \\
\text { of MSMEs } \\
\text { through a NS }\end{array}$ & $\begin{array}{l}\text { Addressing } \\
\text { financial } \\
\text { education needs } \\
\text { of MSMEs } \\
\text { through another } \\
\text { framework }\end{array}$ & Notes \\
\hline Australia & No & To some extent & No & $\begin{array}{l}\text { ASIC had developed tools and resources which } \\
\text { inherently provide assistance to MSMEs } \\
\text { www.Moneysmart.gov.au }\end{array}$ \\
\hline Bangladesh & $\begin{array}{l}\text { To be } \\
\text { decided }\end{array}$ & To be decided & To be decided & $\begin{array}{l}\text { A committee has been created with the intention of } \\
\text { developing a national policy, which will include } \\
\text { financial education in schools, and may target } \\
\text { MSMEs }\end{array}$ \\
\hline Brazil & No & No & To some extent & $\begin{array}{l}\text { SEBRAE has programmes for potential and micro } \\
\text { entrepreneurs }\end{array}$ \\
\hline Chile & $\begin{array}{l}\text { To some } \\
\text { extent }\end{array}$ & To some extent & To some extent & $\begin{array}{l}\text { These aspects are the responsibility of the National } \\
\text { Council for Financial Inclusion. Financial education } \\
\text { currently targets female entrepreneurs, micro and } \\
\text { small enterprises (we have links) }\end{array}$ \\
\hline China & $\begin{array}{l}\text { To some } \\
\text { extent }\end{array}$ & No & To some extent & $\begin{array}{l}\text { A consumer financial literacy survey undertaken } \\
\text { every } 2 \text { years can provide data on MSMEs; and } \\
\text { PBC Financial Literacy Month includes programmes } \\
\text { on financial knowledge in enterprises and institutions }\end{array}$ \\
\hline Colombia & $\begin{array}{l}\text { To some } \\
\text { extent }\end{array}$ & To some extent & no & $\begin{array}{l}\text { The Colombian government's initiative on financial } \\
\text { inclusion; Banca de las Oportunidades started to } \\
\text { measure demand side issues of relevance to natural } \\
\text { persons and micro-enterprises. It will be repeated } \\
\text { every two years and covers, access, planning } \\
\text { business operations, transactional products, } \\
\text { payments, savings, credit, insurance, business } \\
\text { improvements and attitudes towards technology. }\end{array}$ \\
\hline $\begin{array}{l}\text { Czech } \\
\text { Republic }\end{array}$ & No & No & No & \\
\hline Denmark & No & Not applicable & No & \\
\hline
\end{tabular}




\begin{tabular}{|c|c|c|c|c|}
\hline & $\begin{array}{l}\text { Measure } \\
\text { financial } \\
\text { literacy } \\
\text { of } \\
\text { MSMEs }\end{array}$ & $\begin{array}{l}\text { Addressing } \\
\text { financial } \\
\text { education needs } \\
\text { of MSMEs } \\
\text { through a NS }\end{array}$ & $\begin{array}{l}\text { Addressing } \\
\text { financial } \\
\text { education needs } \\
\text { of MSMEs } \\
\text { through another } \\
\text { framework }\end{array}$ & Notes \\
\hline Estonia & $\begin{array}{l}\text { To some } \\
\text { extent }\end{array}$ & To some extent & To some extent & $\begin{array}{l}\text { Financial literacy is measured using the OECD } \\
\text { instrument and a booster sample is used to show } \\
\text { levels among entrepreneurs. The financial literacy } \\
\text { development programme covers MSMEs and the } \\
\text { Ministry for Economic Affairs and Communications } \\
\text { has an Estonian Businesses Growth Strategy which } \\
\text { includes raising knowledge about business models, } \\
\text { development, production, sales and marketing and } \\
\text { competitive positioning. }\end{array}$ \\
\hline $\begin{array}{l}\text { Hong Kong, } \\
\text { China }\end{array}$ & No & No & No & \\
\hline India & No & No & To some extent & $\begin{array}{l}\text { Banks provide financial education to MSMEs } \\
\text { through financial literacy camps }\end{array}$ \\
\hline Indonesia & $\begin{array}{l}\text { To some } \\
\text { extent }\end{array}$ & To some extent & To some extent & $\begin{array}{l}\text { MSMEs are a priority in terms of financial literacy } \\
\text { activities, and mentioned in Indonesia's strategy on } \\
\text { financial literacy. The Chamber of Commerce and } \\
\text { Industry also addresses the financial education } \\
\text { needs of this target group to some extent. }\end{array}$ \\
\hline Italy & $\begin{array}{l}\text { To some } \\
\text { extent }\end{array}$ & No & No & $\begin{array}{l}\text { The Bank of Italy Survey on Household income and } \\
\text { wealth provides some information of financial } \\
\text { literacy of entrepreneurs and managers of firms with } \\
\text { less than } 100 \text { employees }\end{array}$ \\
\hline Jamaica & No & No & To some extent & \\
\hline Japan & No & To some extent & Comprehensively & $\begin{array}{l}\text { The NS for financial education will reach potential } \\
\text { entrepreneurs; including in schools. Financial } \\
\text { education for MSMEs through other frameworks } \\
\text { includes consultation and advice from experts. } \\
\text { Guidelines for supervision of Banks, encourages } \\
\text { consultations and advise giving, including to } \\
\text { MSMEs. }\end{array}$ \\
\hline Kenya & $\begin{array}{l}\text { To some } \\
\text { extent }\end{array}$ & To some extent & To some extent & $\begin{array}{l}\text { Measurement covers women, youth and the informal } \\
\text { sector. Financial education through conferences } \\
\text { and seminars will reach MSMEs. The government } \\
\text { has also established a Youth Enterprise Fund, a } \\
\text { Women Enterprise Fund and Informal Sector Fund. }\end{array}$ \\
\hline Portugal & No & $\begin{array}{l}\text { Yes, in a } \\
\text { comprehensive } \\
\text { manner }\end{array}$ & No & $\begin{array}{l}\text { The Portuguese National Plan for Financial } \\
\text { Education targets entrepreneurs, business-owners } \\
\text { and managers of micro, small and medium-sized } \\
\text { companies, in the scope of a partnership established } \\
\text { between the financial supervisors, IAPMEI (Public } \\
\text { Agency for Competitiveness and Innovation) and } \\
\text { Turismo de Portugal (Public Authority for Tourism) }\end{array}$ \\
\hline Romania & No & Not applicable & No & \\
\hline Serbia & No & Comprehensively & Comprehensively & $\begin{array}{l}\text { Addressed through the Financial Education Strategy } \\
\text { which includes planned lectures throughout Serbia } \\
\text { for citizens, famers, entrepreneurs, SMEs. This work } \\
\text { is in cooperation with other professional } \\
\text { organisations and the office for cooperation with } \\
\text { industry. A National Strategy for Development of } \\
\text { MSMEs includes an Action Plan for Implementation } \\
\text { of the Strategy for SMEs Entrepreneurship and } \\
\text { Competitiveness. }\end{array}$ \\
\hline Slovenia & No & No & No & \\
\hline Spain & No & No & No & \\
\hline Turkey & No & To some extent & No & \\
\hline
\end{tabular}

Responses to stocktake. Responding countries not listed had limited or no information for this section; similarly empty cells indicate that the information was not available. 


\section{Intended policy aims of targeted approaches}

As seen from Table 7, financial education and related support for potential entrepreneurs and MSMEs is being included in certain policy tools; although the response 'to some extent' illustrates that this is not necessarily occurring in a comprehensive way.

Table 8 summarises the reason for targeting MSMEs through policy frameworks. Most countries hope that such policies will encourage and increase entrepreneurship (Colombia is the exception) and reduce demand-side barriers to finance across all sizes of enterprise (Australia is the exception). Stability is also an important goal of financial education for MSMEs in all but China and India.

Financial education for MSMEs is also used as an opportunity to increase formal sector employment in many countries, although, interestingly, this is less clear-cut for potential entrepreneurs in countries such as Indonesia and Turkey, perhaps indicating the fact that many entrepreneurs begin by operating informally.

Whilst financial education curriculums are often designed to help people manage their financial affairs and understand their rights and responsibilities regarding taxes, responses indicate that policies targeting MSMEs are not typically designed to increase tax revenues. Only in Chile, Colombia, Estonia, Indonesia and Serbia is this considered to be a policy goal.

Table 7. Policy aims of financial education

\begin{tabular}{|c|c|c|c|c|c|}
\hline \multirow[b]{2}{*}{ Country } & \multicolumn{5}{|c|}{$\begin{array}{l}\text { (P=potential entrepreneur; Mc=micro-enterprise, } S=s m a l l \text { enterprise } M S=\text { =medium-sized } \\
\text { enterprise) }\end{array}$} \\
\hline & $\begin{array}{l}\text { Encourage and } \\
\text { increase } \\
\text { entrepreneurship }\end{array}$ & $\begin{array}{l}\text { Reduce demand- } \\
\text { side barriers to } \\
\text { accessing finance }\end{array}$ & $\begin{array}{l}\text { Increase } \\
\text { economic } \\
\text { stability }\end{array}$ & $\begin{array}{l}\text { Increase formal } \\
\text { sector } \\
\text { employment }\end{array}$ & $\begin{array}{l}\text { Increase tax } \\
\text { revenues }\end{array}$ \\
\hline Australia & $\mathrm{P}, \mathrm{Mc}, \mathrm{S}, \mathrm{MS}$ & $\mathrm{P}, \mathrm{Mc}, \mathrm{S}, \mathrm{MS}$ & $\mathrm{P}, \mathrm{Mc}, \mathrm{S}, \mathrm{MS}$ & $\mathrm{P}, \mathrm{Mc}, \mathrm{S}, \mathrm{MS}$ & no \\
\hline Bangladesh & $\mathrm{P}, \mathrm{Mc}, \mathrm{S}, \mathrm{MS}$ & P, Mc, S, MS & $\mathrm{P}, \mathrm{Mc}, \mathrm{S}, \mathrm{MS}$ & $\mathrm{P}, \mathrm{Mc}, \mathrm{S}, \mathrm{MS}$ & no \\
\hline Brazil & $\mathrm{P}, \mathrm{Mc}, \mathrm{S}$ & $\mathrm{P}, \mathrm{Mc}, \mathrm{S}$ & $\mathrm{P}, \mathrm{Mc}, \mathrm{S}$ & $\mathrm{P}, \mathrm{Mc}, \mathrm{S}$ & no \\
\hline Chile & $\mathrm{P}, \mathrm{Mc}, \mathrm{S}$ & $\mathrm{P}, \mathrm{Mc}, \mathrm{S}$ & $\mathrm{P}, \mathrm{Mc}, \mathrm{S}, \mathrm{MS}$ & $\mathrm{P}, \mathrm{Mc}$ & $\mathrm{P}, \mathrm{Mc}, \mathrm{S}, \mathrm{MS}$ \\
\hline China & $\mathrm{P}, \mathrm{Mc}$ & $\mathrm{P}, \mathrm{Mc}$ & no & no & no \\
\hline Colombia & no & $\mathrm{P}, \mathrm{Mc}$ & $\mathrm{P}, \mathrm{Mc}, \mathrm{S}, \mathrm{MS}$ & $\mathrm{P}, \mathrm{Mc}$ & $\mathrm{P}, \mathrm{Mc}, \mathrm{S}$ \\
\hline Estonia & $\mathrm{P}, \mathrm{Mc}, \mathrm{S}, \mathrm{MS}$ & P, Mc, S, MS & $\mathrm{P}, \mathrm{Mc}, \mathrm{S}, \mathrm{MS}$ & $\mathrm{P}, \mathrm{Mc}, \mathrm{S}, \mathrm{MS}$ & $\mathrm{P}, \mathrm{Mc}, \mathrm{S}, \mathrm{MS}$ \\
\hline India & $\mathrm{P}, \mathrm{Mc}, \mathrm{S}, \mathrm{MS}$ & P, Mc, S, MS & no & $\mathrm{P}, \mathrm{Mc}, \mathrm{S}, \mathrm{MS}$ & no \\
\hline Indonesia & $\mathrm{P}, \mathrm{Mc}, \mathrm{S}, \mathrm{MS}$ & $\mathrm{P}, \mathrm{Mc}, \mathrm{S}, \mathrm{MS}$ & $\mathrm{P}, \mathrm{Mc}, \mathrm{S}, \mathrm{MS}$ & Mc, S, MS & Mc, S, MS \\
\hline Jamaica & $\mathrm{P}, \mathrm{Mc}, \mathrm{S}, \mathrm{MS}$ & $\mathrm{P}, \mathrm{S}, \mathrm{MS}$ & $\mathrm{P}, \mathrm{Mc}, \mathrm{S}, \mathrm{MS}$ & $\mathrm{P}, \mathrm{S}, \mathrm{MS}$ & no \\
\hline Japan' & $\mathrm{P}, \mathrm{Mc}, \mathrm{S}, \mathrm{MS}$ & P, Mc, S, MS & & & \\
\hline Kenya & $\mathrm{P}, \mathrm{Mc}, \mathrm{S}, \mathrm{MS}$ & $\mathrm{P}, \mathrm{Mc}, \mathrm{S}, \mathrm{MS}$ & $\mathrm{P}, \mathrm{Mc}, \mathrm{S}, \mathrm{MS}$ & $\mathrm{P}, \mathrm{Mc}, \mathrm{S}, \mathrm{MS}$ & no \\
\hline Portugal & $\mathrm{P}, \mathrm{Mc}, \mathrm{S}, \mathrm{MS}$ & P, Mc, S, MS & $\mathrm{P}, \mathrm{Mc}, \mathrm{S}, \mathrm{MS}$ & no & no \\
\hline Serbia & $\mathrm{P}, \mathrm{Mc}, \mathrm{S}, \mathrm{MS}$ & P, Mc, S, MS & $\mathrm{P}, \mathrm{Mc}, \mathrm{S}, \mathrm{MS}$ & $\mathrm{P}, \mathrm{Mc}, \mathrm{S}, \mathrm{MS}$ & $\mathrm{P}, \mathrm{Mc}, \mathrm{S}, \mathrm{MS}$ \\
\hline Turkey & Mc, S, MS & Mc, S, MS & Mc, S, MS & Mc, S, MS & no \\
\hline
\end{tabular}

1. Japan also noted the importance of increasing vitalisation: $P, M c, S, M S$.

Responses to stocktake. Responding countries not listed had limited or no information for this section; similarly empty cells indicate that the information was not available. 


\section{Section III. Stakeholder involvement and delivery}

\section{Stakeholders providing financial education, practical support and guidance to MSMEs}

In addition to the strategic approaches to financial education for MSMEs, the stocktake questionnaire also asked more generally about financial education, practical support and guidance provided to this group and the stakeholders responsible (Table 9).

The public sector is providing some such support to MSMEs in 17 of the responding countries. This provision is often on a large scale (and sometimes also at the local level) and targeted at all sizes of enterprise as well as potential entrepreneurs. Notable exceptions include Denmark and Hong Kong, China where the public sector targets only the local level and Chile, where the public sector does not target medium-sized enterprises with financial education (indeed, in Chile, none of the sectors appear to target these enterprises).

The education sector - including universities and colleges - has a role in fewer countries, but reaches a surprisingly broad cross-section of businesses - from potential entrepreneurs through to medium-sized enterprises in most cases. This suggests a flexible approach to education provision that meets the needs of busy professionals.

In some countries, the focus of the education sector appears to vary by region with only local provision available, whereas elsewhere (such as Colombia, Estonia, Kenya, Serbia, Spain and to some extent, Turkey) there is national provision.

Industry organisations and trade unions are active in 12 countries. They tend to play a role at the local level across most or all sizes of enterprise. Notable exceptions to this overall picture are Bangladesh, Estonia, Japan and Turkey where they are also active on a larger scale; and Chile (potential and micro) and Colombia (small), where they are only reaching smaller enterprises. Individual employers may also have a role (see Box 5). 


\section{Box 5. The role of financial education in the workplace}

Entrepreneurs and managers of MSMEs, in their capacity as employers, can introduce financial education programmes in the workplace so as to raise financial awareness of their employees and encourage them to manage their personal finances better. Workplace financial education can help MSME employees establish financial goals and assist them in achieving them. This is particularly important for start-ups and micro businesses with riskier business plans; financial education in the workplace can encourage start-up employees to save more to protect themselves against potential uncertainty involved in riskier projects.

Workplace financial education can potentially help MSME employees understand and make the most of their workplace benefits or reward packages. Although such programmes are mostly delivered in medium- and larger-sized enterprises due to the economies of scale and practicality of providing training to a group of people simultaneously, they could also be beneficial for small enterprises, if designed properly so as to minimise the negative impact on the business - perhaps most notably when it comes to pension benefits. Making informed choices about a pension plan and managing the risks that can arise under a defined contribution pension scheme is of paramount importance for employees of all business sizes (including self-employed entrepreneurs), as people need to understand how much they need to save and where they need to invest in order to achieve their retirement goals. For smaller businesses it may be necessary to offer training outside of work hours through associations or other providers, or to develop digital training solutions that can be used at a time to suit each individual.

Financial literacy can ultimately contribute to the well-being of workers by providing them with the information and skills to make wise investment choices with both their pension plans and any individual savings plans but also better manage their day-to-day finances. The case for workplace financial education is supported by improved motivation, higher retention levels of employees, better alignment of employer and employee needs and improved productivity levels (CIPD, 2012).

Charities and not-for-profit organisations have an important role to play in many of the countries, operation at a national (and sometimes local) level in Australia, Chile, China, Colombia, Estonia, Japan, Serbia, Spain and Turkey. Elsewhere their role at a local level is also evident across all sizes of enterprise (Brazil, India and Jamaica).

The financial sector also provides financial education, support or guidance to enterprises in 18 of the responding countries; in Italy it appears to be the only stakeholder group making this provision. The financial sector is often present at the national level - possibly indicating the role of larger companies or industry bodies (see also Box 6). 


\section{Box 6. The Elite Platform of the London Stock Exchange Group}

The ELITE is a programme delivered by the London Stock Exchange Group, designed to help SMEs prepare and structure for the next stage of growth through the access to long term financing opportunities. The long term objective of ELITE is to improve the MSMEs access to more sophisticated skill-sets, network and a diversified capital pool in order to accelerate their growth opportunities and facilitate a future possible listing in the public equity market.

The programme includes training of MSME managers, a working zone supported by a tutorship model and direct access to the financial community through dedicated digital community facilities. It is "capital neutral" to any financing opportunity, providing access to Private Equity and Venture Capital funds, debt products, and other sources of financing,

Although the programme is mostly targeting high-growth and high-potential MSMEs with sound business models, clear growth strategy and a desire to obtain (mostly public) funding in the near future, it is an important example of a financial education programme delivered by the financial sector. In addition to comprehensive training to MSME managers and entrepreneurs, the ELITE programme provides a platform to a network of local and international advisers, investors, experts, as well as entrepreneurs and companies with similar objectives and aspirations. The companies can therefore take advantage of the tools that such network can offer, including inter alia mentoring and peer learning opportunities.

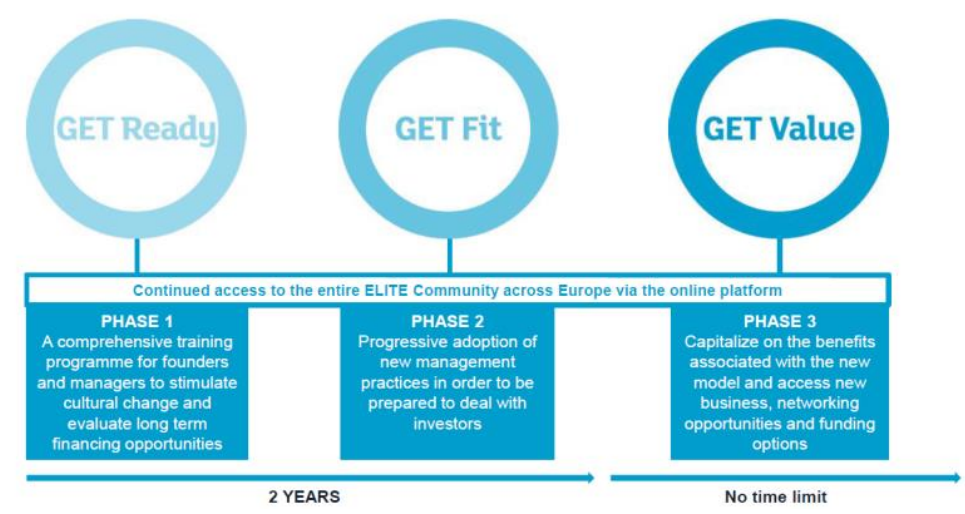

The ELITE programme was launched by the London Stock Exchange Group in April 2012 at Borsa Italiana (Italy), followed by a programme launched in the UK in April 2014. Since 2012 it has attracted over 400 companies, 150 financial advisers and professional bodies and 100 institutional investors (private equity firms and debt investors).

Source: London Stock Exchange Group (2016).

International NGOs have a relatively low level of involvement in financial education for MSMEs in the responding countries. They have some presence in Australia, China, Colombia, Estonia, India, Indonesia, Jamaica, Romania and Turkey, but only at the local level in three of these countries (India, Jamaica and Romania), and only reaching certain sizes of enterprise in China, Colombia and Turkey.

Overall, Table 8 shows that, with the exception of the Czech Republic, all responding countries are aware of some stakeholder involvement in financial education for MSMEs, indicating that at least some entrepreneurs can access relevant information. However, in Chile there is no provision of medium-sized enterprises and in Denmark; Hong Kong, China; and Italy there is only very limited provision and this is exclusively at the local level. 
Table 8. Providers of financial education

\begin{tabular}{|c|c|c|c|c|c|c|c|}
\hline \multirow[b]{2}{*}{ Country } & & \multicolumn{6}{|c|}{$\begin{array}{l}\text { (P=potential entrepreneur; Mc=micro-enterprise, } \mathrm{S}=\text { =small enterprise } \\
\text { MS=medium-sized enterprise) }\end{array}$} \\
\hline & & 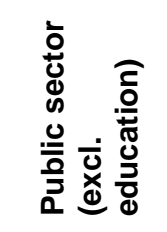 & 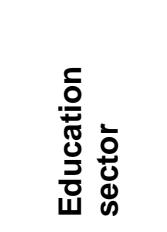 & 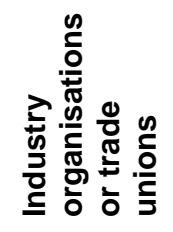 & 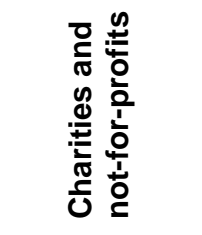 & 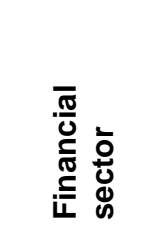 & 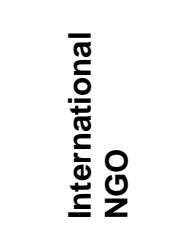 \\
\hline \multirow{2}{*}{ Australia } & Large/national & $\begin{array}{l}\mathrm{P}, \mathrm{Mc}, \mathrm{S} \\
\mathrm{MS}\end{array}$ & no & no & $\mathrm{P}, \mathrm{Mc}, \mathrm{S}, \mathrm{MS}$ & $\begin{array}{l}\mathrm{P}, \mathrm{Mc}, \mathrm{S} \\
\mathrm{MS}\end{array}$ & $\mathrm{P}, \mathrm{Mc}, \mathrm{S}, \mathrm{MS}$ \\
\hline & Local & $\begin{array}{l}\text { P, Mc, S, } \\
\text { MS }\end{array}$ & $\begin{array}{l}\text { P, Mc, S, } \\
\text { MS }\end{array}$ & $\begin{array}{l}\text { P, Mc, S, } \\
\text { MS }\end{array}$ & $\mathrm{P}, \mathrm{Mc}, \mathrm{S}, \mathrm{MS}$ & no & $\mathrm{P}, \mathrm{Mc}, \mathrm{S}, \mathrm{MS}$ \\
\hline \multirow{2}{*}{ Bangladesh } & Large/national & $\begin{array}{l}\text { P, Mc, S, } \\
\text { MS }\end{array}$ & $\begin{array}{l}\text { P, Mc, S, } \\
\text { MS }\end{array}$ & $\begin{array}{l}\text { P, Mc, S, } \\
\text { MS }\end{array}$ & no & $\begin{array}{l}\text { P, Mc, S, } \\
\text { MS }\end{array}$ & no \\
\hline & Local & $\begin{array}{l}\text { P, Mc, S, } \\
\text { MS }\end{array}$ & $\begin{array}{l}\text { P, Mc, S, } \\
\text { MS }\end{array}$ & $\begin{array}{l}\text { P, Mc, S, } \\
\text { MS }\end{array}$ & no & $\begin{array}{l}\text { P, Mc, S, } \\
\text { MS }\end{array}$ & no \\
\hline \multirow{2}{*}{ Brazil } & Large/national & no & no & no & no & $\mathrm{S}, \mathrm{MS}$ & no \\
\hline & Local & no & $\mathrm{P}, \mathrm{Mc}, \mathrm{S}$ & no & $\mathrm{P}, \mathrm{Mc}, \mathrm{S}, \mathrm{MS}$ & S, MS & no \\
\hline \multirow{2}{*}{ Chile } & Large/national & $\mathrm{P}, \mathrm{Mc}, \mathrm{S}$ & no & no & $\mathrm{P}, \mathrm{Mc}$ & $\mathrm{P}, \mathrm{Mc}, \mathrm{S}$ & no \\
\hline & Local & $\mathrm{P}, \mathrm{Mc}, \mathrm{S}$ & no & $\mathrm{P}, \mathrm{Mc}$ & no & no & no \\
\hline \multirow{2}{*}{ China } & Large/national & $\begin{array}{l}\text { P, Mc, S, } \\
\text { MS }\end{array}$ & no & no & S, MS & S, MS & S, MS \\
\hline & Local & no & $\begin{array}{l}\text { P, Mc, S, } \\
\text { MS }\end{array}$ & $\begin{array}{l}\text { P, Mc, S, } \\
\text { MS }\end{array}$ & $\mathrm{P}, \mathrm{Mc}$ & $\mathrm{P}, \mathrm{Mc}$ & $\mathrm{P}, \mathrm{Mc}$ \\
\hline \multirow{2}{*}{ Colombia } & Large/national & $\mathrm{P}, \mathrm{Mc}, \mathrm{S}$ & Mc, S, MS & $\mathrm{S}$ & $\mathrm{P}, \mathrm{Mc}, \mathrm{S}$ & $\mathrm{P}, \mathrm{Mc}, \mathrm{S}$ & $\mathrm{P}, \mathrm{Mc}, \mathrm{S}$ \\
\hline & Local & Mc & Mc & no & $\mathrm{P}, \mathrm{Mc}$ & $\mathrm{P}, \mathrm{Mc}$ & $\mathrm{P}, \mathrm{Mc}$ \\
\hline \multirow[b]{2}{*}{ Denmark } & Large/national & no & no & no & no & no & no \\
\hline & Local & $\begin{array}{l}\text { P, Mc, S, } \\
\text { MS }\end{array}$ & no & no & no & no & no \\
\hline \multirow{2}{*}{ Estonia } & Large/national & $\begin{array}{l}\text { P, Mc, S, } \\
\text { MS }\end{array}$ & $\begin{array}{l}\text { P, Mc, S, } \\
\text { MS }\end{array}$ & $\begin{array}{l}\mathrm{P}, \mathrm{Mc}, \mathrm{S}, \\
\mathrm{MS}\end{array}$ & $\mathrm{P}, \mathrm{Mc}, \mathrm{S}, \mathrm{MS}$ & $\begin{array}{l}\text { P, Mc, S, } \\
\text { MS }\end{array}$ & $\mathrm{P}, \mathrm{Mc}, \mathrm{S}, \mathrm{MS}$ \\
\hline & Local & $\begin{array}{l}\mathrm{P}, \mathrm{Mc}, \mathrm{S}, \\
\mathrm{MS}\end{array}$ & $\begin{array}{l}\mathrm{P}, \mathrm{Mc}, \mathrm{S}, \\
\mathrm{MS}\end{array}$ & $\begin{array}{l}\mathrm{P}, \mathrm{Mc}, \mathrm{S}, \\
\mathrm{MS}\end{array}$ & $\mathrm{P}, \mathrm{Mc}, \mathrm{S}, \mathrm{MS}$ & $\begin{array}{l}\mathrm{P}, \mathrm{Mc}, \mathrm{S}, \\
\mathrm{MS}\end{array}$ & $\mathrm{P}, \mathrm{Mc}, \mathrm{S}, \mathrm{MS}$ \\
\hline \multirow{2}{*}{$\begin{array}{l}\text { Hong Kong, } \\
\text { China }\end{array}$} & Large/national & no & no & no & no & no & no \\
\hline & Local & $\begin{array}{l}\text { P, Mc, S, } \\
\text { MS }\end{array}$ & no & $\begin{array}{l}\text { P, Mc, S, } \\
\text { MS }\end{array}$ & $\mathrm{P}, \mathrm{Mc}$ & no & yes \\
\hline \multirow[b]{2}{*}{ India } & Large/national & no & no & no & no & no & no \\
\hline & Local & $\begin{array}{l}\mathrm{P}, \mathrm{Mc}, \mathrm{S}, \\
\mathrm{MS}\end{array}$ & $\begin{array}{l}\mathrm{P}, \mathrm{Mc}, \mathrm{S}, \\
\mathrm{MS}\end{array}$ & $\begin{array}{l}\mathrm{P}, \mathrm{Mc}, \mathrm{S}, \\
\mathrm{MS}\end{array}$ & $\mathrm{P}, \mathrm{Mc}, \mathrm{S}, \mathrm{MS}$ & $\begin{array}{l}\mathrm{P}, \mathrm{Mc}, \mathrm{S}, \\
\mathrm{MS}\end{array}$ & $\mathrm{P}, \mathrm{Mc}, \mathrm{S}, \mathrm{MS}$ \\
\hline \multirow[t]{2}{*}{ Indonesia } & Large/national & $\begin{array}{l}\mathrm{P}, \mathrm{Mc}, \mathrm{S}, \\
\mathrm{MS}\end{array}$ & no & no & no & $\begin{array}{l}\mathrm{P}, \mathrm{Mc}, \mathrm{S}, \\
\mathrm{MS}\end{array}$ & $\mathrm{P}, \mathrm{Mc}, \mathrm{S}, \mathrm{MS}$ \\
\hline & Local & no & $\mathrm{P}$ & no & no & no & no \\
\hline \multirow{2}{*}{ Italy } & Large/national & no & no & no & no & no & no \\
\hline & Local & no & no & no & no & S, MS & no \\
\hline \multirow[b]{2}{*}{ Jamaica } & Large/national & Mc, S, MS & no & no & no & no & no \\
\hline & Local & $\mathrm{P}$ & $\begin{array}{l}\text { P, Mc, S, } \\
\text { MS }\end{array}$ & $\begin{array}{l}\text { P, Mc, S, } \\
\text { MS }\end{array}$ & $\mathrm{P}, \mathrm{Mc}, \mathrm{S}, \mathrm{MS}$ & $\begin{array}{l}\mathrm{P}, \mathrm{Mc}, \mathrm{S}, \\
\mathrm{MS}\end{array}$ & $\mathrm{P}, \mathrm{Mc}, \mathrm{S}, \mathrm{MS}$ \\
\hline \multirow{2}{*}{ Japan } & Large/national & $\begin{array}{l}\text { P, Mc, S, } \\
\text { MS }\end{array}$ & $P$ & $\begin{array}{l}\text { P, Mc, S, } \\
\text { MS }\end{array}$ & $\mathrm{P}, \mathrm{Mc}, \mathrm{S}, \mathrm{MS}$ & $\begin{array}{l}\mathrm{P}, \mathrm{Mc}, \mathrm{S}, \\
\mathrm{MS}\end{array}$ & \\
\hline & Local & $\begin{array}{l}\text { P, Mc, S, } \\
\text { MS }\end{array}$ & $P$ & $\begin{array}{l}\text { P, Mc, S, } \\
\text { MS }\end{array}$ & & $\begin{array}{l}\text { P, Mc, S, } \\
\text { MS }\end{array}$ & \\
\hline \multirow[b]{2}{*}{ Kenya } & Large/national & $\begin{array}{l}\text { P, Mc, S, } \\
\text { MS }\end{array}$ & $\begin{array}{l}\text { P, Mc, S, } \\
\text { MS }\end{array}$ & no & no & $\begin{array}{l}\text { P, Mc, S, } \\
\text { MS }\end{array}$ & no \\
\hline & Local & $\begin{array}{l}\mathrm{P}, \mathrm{Mc}, \mathrm{S}, \\
\mathrm{MS}\end{array}$ & $\begin{array}{l}\mathrm{P}, \mathrm{Mc}, \mathrm{S}, \\
\mathrm{MS}\end{array}$ & no & no & $\begin{array}{l}\mathrm{P}, \mathrm{Mc}, \mathrm{S}, \\
\mathrm{MS}\end{array}$ & no \\
\hline
\end{tabular}




\begin{tabular}{|c|c|c|c|c|c|c|c|}
\hline \multirow[b]{2}{*}{ Country } & & \multicolumn{6}{|c|}{$\begin{array}{l}\text { ( } \mathrm{P}=\text { potential entrepreneur; Mc=micro-enterprise, } \mathrm{S}=\text { =small enterprise } \\
\text { MS=medium-sized enterprise) }\end{array}$} \\
\hline & & 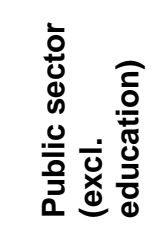 & 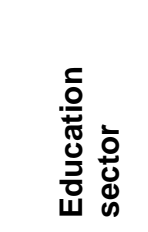 & 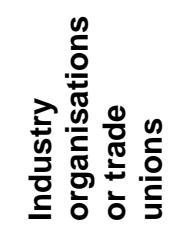 & 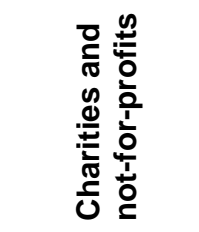 & 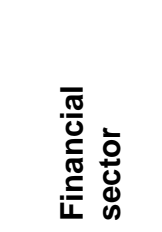 & 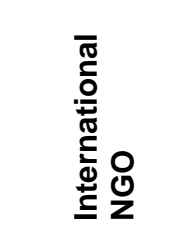 \\
\hline \multirow[b]{2}{*}{ Portugal } & Large/national & $\begin{array}{l}\text { P, Mc, S, } \\
\text { MS }\end{array}$ & $\mathrm{P}$ & $\begin{array}{l}\mathrm{P}, \mathrm{Mc}, \mathrm{S} \\
\mathrm{MS}\end{array}$ & no & no & no \\
\hline & Local & $\begin{array}{l}\text { P, Mc, S, } \\
\text { MS }\end{array}$ & $P$ & $\begin{array}{l}\mathrm{P}, \mathrm{Mc}, \mathrm{S}, \\
\mathrm{MS}\end{array}$ & no & no & no \\
\hline \multirow[b]{2}{*}{ Romania } & Large/national & $\begin{array}{l}\text { P, Mc, S, } \\
\text { MS }\end{array}$ & no & no & no & no & no \\
\hline & Local & no & no & $\begin{array}{l}\text { P, Mc, S, } \\
\text { MS }\end{array}$ & no & $\begin{array}{l}\text { P, Mc, S, } \\
\text { MS }\end{array}$ & $\mathrm{P}, \mathrm{Mc}, \mathrm{S}, \mathrm{MS}$ \\
\hline \multirow{2}{*}{ Serbia } & Large/national & $\begin{array}{l}\mathrm{P}, \mathrm{Mc}, \mathrm{S} \\
\text { MS }\end{array}$ & $\begin{array}{l}\mathrm{P}, \mathrm{Mc}, \mathrm{S} \\
\mathrm{MS}\end{array}$ & no & $\mathrm{P}, \mathrm{Mc}, \mathrm{S}, \mathrm{MS}$ & $\begin{array}{l}\mathrm{P}, \mathrm{Mc}, \mathrm{S} \\
\mathrm{MS}\end{array}$ & no \\
\hline & Local & $\begin{array}{l}\text { P, Mc, S, } \\
\text { MS }\end{array}$ & no & no & $\mathrm{P}$ & no & no \\
\hline \multirow[t]{2}{*}{ Slovenia } & Large/national & no & no & no & no & $\begin{array}{l}\text { P, Mc, S, } \\
\text { MS }\end{array}$ & no \\
\hline & Local & no & no & no & no & no & no \\
\hline \multirow{2}{*}{ Spain } & Large/national & $\begin{array}{l}\text { P, Mc, S, } \\
\text { MS }\end{array}$ & $\begin{array}{l}\text { P, Mc, S, } \\
\text { MS }\end{array}$ & no & $\mathrm{P}, \mathrm{Mc}, \mathrm{S}, \mathrm{MS}$ & $\begin{array}{l}\text { P, Mc, S, } \\
\text { MS }\end{array}$ & no \\
\hline & Local & $\begin{array}{l}\text { P, Mc, S, } \\
\text { MS }\end{array}$ & no & no & no & no & no \\
\hline \multirow[t]{2}{*}{ Turkey } & Large/national & $\begin{array}{l}\text { P, Mc, S, } \\
\text { MS }\end{array}$ & $\mathrm{P}$ & Mc, S, MS & $\mathrm{P}, \mathrm{Mc}, \mathrm{S}, \mathrm{MS}$ & $\begin{array}{l}\mathrm{P}, \mathrm{Mc}, \mathrm{S} \\
\mathrm{MS}\end{array}$ & Mc, S, MS \\
\hline & Local & & Mc, S, MS & Mc, S, MS & Mc, S, MS & Mc, S, MS & no \\
\hline
\end{tabular}

Responses to stocktake. Responding countries not listed had limited or no information for this section; similarly empty cells indicate that the information was not available.

\section{Content of financial education provided}

Financial education for entrepreneurs needs to cover a wide range of topics in order to meet the various policy goals indicated above.

The vast majority of countries that are trying to provide financial education to MSMEs within a policy framework include general elements of financial literacy for at least the smallest players (potential and/or micro-enterprises) - Estonia focuses exclusively on this (Table 9). The provision of basic financial literacy that reaches MSMEs may come from a comprehensive national strategy for financial education that specifically identifies entrepreneurs as a target group, as in Indonesia, Portugal and Serbia.

Table 9 indicates that a breadth of topics is common; indeed six responding countries indicate that financial education is available on each of the topics listed (Bangladesh - planned, Chile, Colombia, Indonesia, Jamaica and Japan). In Colombia such education is only available to potential entrepreneurs and micro-enterprises whilst elsewhere, different aspects of financial education are available to different groups. In Jamaica for example, potential entrepreneurs receive general financial literacy, and special effort is made to help them to understand the different between personal and business finance, but most other training focuses on larger enterprises.

Among the topics listed, managing financial records is the least likely to be specifically covered (10 countries indicated that this topic is available). This may be because it is offered within general financial literacy classes, but such generic education may not be sufficiently detailed for entrepreneurs. 
Table 9. Content of financial education

\begin{tabular}{|c|c|c|c|c|c|c|c|c|c|}
\hline \multirow[b]{2}{*}{ Country } & \multicolumn{9}{|c|}{ ( $P=$ potential entrepreneur; $M c=$ micro-enterprise, $S=$ =small enterprise $M S=$ medium-sized enterprise) } \\
\hline & $\begin{array}{l}\text { General } \\
\text { financial } \\
\text { literacy }\end{array}$ & $\begin{array}{l}\text { Knowing } \\
\text { where to go } \\
\text { for help on } \\
\text { financial } \\
\text { matters }\end{array}$ & $\begin{array}{l}\text { Recognising } \\
\text { the interaction } \\
\text { between } \\
\text { personal and } \\
\text { business } \\
\text { finance }\end{array}$ & $\begin{array}{l}\text { Understanding } \\
\text { the business, } \\
\text { financial and } \\
\text { economic } \\
\text { landscape }\end{array}$ & $\begin{array}{l}\text { Planning } \\
\text { and } \\
\text { managing } \\
\text { business } \\
\text { finances }\end{array}$ & $\begin{array}{l}\text { Managing } \\
\text { financial } \\
\text { records }\end{array}$ & $\begin{array}{l}\text { Being aware } \\
\text { of financing } \\
\text { opportunities }\end{array}$ & $\begin{array}{l}\text { Knowing 1) how to } \\
\text { interact with } \\
\text { investors and } \\
\text { lenders; 2) how to } \\
\text { meet requirement }\end{array}$ & $\begin{array}{l}\text { Being aware of } \\
\text { financial risks and } \\
\text { opportunities and } \\
\text { managing them } \\
\text { effectively }\end{array}$ \\
\hline Australia & $\mathrm{P}, \mathrm{Mc}, \mathrm{S}, \mathrm{MS}$ & $\begin{array}{l}\mathrm{P}, \mathrm{Mc}, \mathrm{S} \\
\mathrm{MS}\end{array}$ & $\mathrm{P}, \mathrm{Mc}, \mathrm{S}, \mathrm{MS}$ & $\mathrm{P}, \mathrm{Mc}, \mathrm{S}, \mathrm{MS}$ & $\mathrm{P}, \mathrm{Mc}, \mathrm{S}, \mathrm{MS}$ & $\mathrm{P}, \mathrm{Mc}, \mathrm{S}, \mathrm{MS}$ & no & No; no & $\mathrm{P}, \mathrm{Mc}, \mathrm{S}, \mathrm{MS}$ \\
\hline Bangladesh & $\mathrm{P}, \mathrm{Mc}, \mathrm{S}, \mathrm{MS}$ & $\begin{array}{l}\text { P, Mc, S, } \\
\text { MS }\end{array}$ & $\mathrm{P}, \mathrm{Mc}, \mathrm{S}, \mathrm{MS}$ & $\mathrm{P}, \mathrm{Mc}, \mathrm{S}, \mathrm{MS}$ & $\mathrm{P}, \mathrm{Mc}, \mathrm{S}, \mathrm{MS}$ & $\mathrm{P}, \mathrm{Mc}, \mathrm{S}, \mathrm{MS}$ & $\mathrm{P}, \mathrm{Mc}, \mathrm{S}, \mathrm{MS}$ & $\begin{array}{l}\text { Both: (P, Mc, S, } \\
\text { MS) }\end{array}$ & $\mathrm{P}, \mathrm{Mc}, \mathrm{S}, \mathrm{MS}$ \\
\hline Brazil & $\mathrm{P}, \mathrm{Mc}, \mathrm{S}$ & $\mathrm{P}, \mathrm{Mc}, \mathrm{S}$ & $\mathrm{P}, \mathrm{Mc}, \mathrm{S}$ & $\mathrm{P}, \mathrm{Mc}, \mathrm{S}$ & $\mathrm{P}, \mathrm{Mc}, \mathrm{S}$ & $\mathrm{P}, \mathrm{Mc}, \mathrm{S}$ & no & Both: (P, Mc, S) & $\mathrm{P}, \mathrm{Mc}$ \\
\hline Chile & $\mathrm{P}, \mathrm{Mc}$ & $\begin{array}{l}\mathrm{P}, \mathrm{Mc}, \mathrm{S} \\
\mathrm{MS}\end{array}$ & $\mathrm{P}, \mathrm{Mc}, \mathrm{S}$ & $\mathrm{P}, \mathrm{Mc}, \mathrm{S}$ & $\mathrm{P}, \mathrm{Mc}, \mathrm{S}$ & $\mathrm{P}, \mathrm{Mc}, \mathrm{S}$ & $\mathrm{P}, \mathrm{Mc}$ & Both: (P, Mc, S) & $\mathrm{P}, \mathrm{Mc}, \mathrm{S}, \mathrm{MS}$ \\
\hline China & $\mathrm{P}, \mathrm{Mc}, \mathrm{S}, \mathrm{MS}$ & $\begin{array}{l}\mathrm{P}, \mathrm{Mc}, \mathrm{S}, \\
\mathrm{MS}\end{array}$ & no & no & $\mathrm{P}, \mathrm{Mc}, \mathrm{S}, \mathrm{MS}$ & & Mc, S, MS & $\begin{array}{l}\text { 1) (S, MS; P) 2) (S, } \\
M S)\end{array}$ & $\mathrm{P}, \mathrm{Mc}, \mathrm{S}, \mathrm{MS}$ \\
\hline Colombia & $\mathrm{P}, \mathrm{Mc}$ & $\mathrm{P}, \mathrm{Mc}$ & $\mathrm{P}, \mathrm{Mc}$ & $\mathrm{P}, \mathrm{Mc}, \mathrm{S}$ & $\mathrm{P}, \mathrm{Mc}$ & $\mathrm{P}, \mathrm{Mc}$ & $\mathrm{P}, \mathrm{Mc}$ & Both: (P, Mc, S) & $\mathrm{P}, \mathrm{Mc}$ \\
\hline Estonia & $\mathrm{P}, \mathrm{Mc}, \mathrm{S}, \mathrm{MS}$ & no & no & no & no & no & no & no & no \\
\hline India & $\mathrm{P}, \mathrm{Mc}, \mathrm{S}, \mathrm{MS}$ & $\begin{array}{l}\mathrm{P}, \mathrm{Mc}, \mathrm{S} \\
\mathrm{MS}\end{array}$ & no & no & no & no & $\mathrm{P}, \mathrm{Mc}, \mathrm{S}, \mathrm{MS}$ & no & no \\
\hline Indonesia & $\mathrm{P}, \mathrm{Mc}, \mathrm{S}, \mathrm{MS}$ & $\begin{array}{l}\text { P, Mc, S, } \\
\text { MS }\end{array}$ & $\mathrm{P}, \mathrm{Mc}, \mathrm{S}, \mathrm{MS}$ & S, MS & $\mathrm{P}, \mathrm{Mc}, \mathrm{S}, \mathrm{MS}$ & $\mathrm{P}, \mathrm{Mc}, \mathrm{S}, \mathrm{MS}$ & $\mathrm{P}, \mathrm{Mc}, \mathrm{S}, \mathrm{MS}$ & $\begin{array}{l}\text { Both: (P, Mc, S, } \\
\text { MS) }\end{array}$ & $\mathrm{P}, \mathrm{Mc}, \mathrm{S}, \mathrm{MS}$ \\
\hline Jamaica & $\mathrm{P}, \mathrm{Mc}, \mathrm{S}, \mathrm{MS}$ & $\begin{array}{l}\mathrm{P}, \mathrm{Mc}, \mathrm{S}, \\
\mathrm{MS}\end{array}$ & $\mathrm{P}, \mathrm{Mc}, \mathrm{S}, \mathrm{MS}$ & $\mathrm{P}, \mathrm{S}, \mathrm{MS}$ & $\mathrm{S}, \mathrm{MS}$ & $\mathrm{P}, \mathrm{Mc}, \mathrm{S}, \mathrm{MS}$ & S, MS & Both: (S, MS) & S, MS \\
\hline Japan & $\mathrm{P}$ & Mc, S, MS & $\mathrm{P}, \mathrm{Mc}, \mathrm{S}, \mathrm{MS}$ & Mc, S, MS & Mc, S, MS & Mc, S, MS & Mc, S, MS & Both: (Mc, S, MS) & $\mathrm{P}, \mathrm{Mc}, \mathrm{S}, \mathrm{MS}$ \\
\hline Kenya & no & $\begin{array}{l}\mathrm{P}, \mathrm{Mc}, \mathrm{S}, \\
\mathrm{MS}\end{array}$ & $\mathrm{P}, \mathrm{Mc}, \mathrm{S}, \mathrm{MS}$ & $\mathrm{P}, \mathrm{Mc}, \mathrm{S}, \mathrm{MS}$ & $\mathrm{P}, \mathrm{Mc}, \mathrm{S}, \mathrm{MS}$ & $\mathrm{P}, \mathrm{Mc}, \mathrm{S}, \mathrm{MS}$ & $\mathrm{P}, \mathrm{Mc}, \mathrm{S}, \mathrm{MS}$ & $\begin{array}{l}\text { Both: (P, Mc, S, } \\
\text { MS) }\end{array}$ & no \\
\hline Portugal & $\mathrm{P}, \mathrm{Mc}, \mathrm{S}, \mathrm{MS}$ & $\begin{array}{l}\mathrm{P}, \mathrm{Mc}, \mathrm{S} \\
\mathrm{MS}\end{array}$ & $\mathrm{P}, \mathrm{Mc}, \mathrm{S}, \mathrm{MS}$ & $\mathrm{P}, \mathrm{Mc}, \mathrm{S}, \mathrm{MS}$ & $\mathrm{P}, \mathrm{Mc}, \mathrm{S}, \mathrm{MS}$ & $\mathrm{P}, \mathrm{Mc}, \mathrm{S}, \mathrm{MS}$ & $\mathrm{P}, \mathrm{Mc}, \mathrm{S}, \mathrm{MS}$ & $\mathrm{P}, \mathrm{Mc}, \mathrm{S}, \mathrm{MS}$ & $\mathrm{P}, \mathrm{Mc}, \mathrm{S}, \mathrm{MS}$ \\
\hline Serbia & $\mathrm{P}, \mathrm{Mc}, \mathrm{S}, \mathrm{MS}$ & $\begin{array}{l}\mathrm{P}, \mathrm{Mc}, \mathrm{S}, \\
\mathrm{MS}\end{array}$ & $\mathrm{P}, \mathrm{Mc}, \mathrm{S}, \mathrm{MS}$ & $\mathrm{P}, \mathrm{Mc}, \mathrm{S}, \mathrm{MS}$ & $\mathrm{P}, \mathrm{Mc}, \mathrm{S}, \mathrm{MS}$ & no & $\mathrm{P}, \mathrm{Mc}, \mathrm{S}, \mathrm{MS}$ & $\begin{array}{l}\text { Both: (P, Mc, S, } \\
\text { MS) }\end{array}$ & $\mathrm{P}, \mathrm{Mc}, \mathrm{S}, \mathrm{MS}$ \\
\hline Turkey & no & no & Mc, S, MS & Mc, S, MS & Mc, S, MS & Mc, S, MS & Mc, S, MS & Both: (Mc, S, MS) & Mc, S, MS \\
\hline
\end{tabular}

Responses to stocktake. Responding countries not listed had limited or no information for this section; similarly empty cells indicate that the information was not available. 


\section{Common delivery channels}

Financial education is provided through a wide range of channels and as indicated in Table 9, MSMEs can gain access to financial education, information or guidance in a variety of ways.

Financial education and entrepreneurship education is available to potential entrepreneurs through school and/or university in almost all responding countries; although as noted above this may not necessarily be at a national level. In Japan there is even a specific institute - the SME Training Institute in Organisation for Small and Medium Enterprise and Regional Innovation (SMRJ) - providing seminars to owners, managers and senior staff of SMEs, whose main purpose is to support MSMEs business inclusively. In Korea, financial education begins in high school and special high schools with a focus on accounting, finance and marketing also exist (17 of these special high schools are in Seoul). In addition, the Small and Medium Business Administration designates "Start-up Leading Universities" and "Start-up Academies for Youth" at each region and supports MSMEs with training and coaching throughout the process of starting a business. Financial education also reaches this target group through a variety of other delivery methods in most countries, particular seminars and public sector advice and guidance.

In general, different delivery channels are used to reach all sizes of enterprise, perhaps indicating the need for a variety of options in order to meet the preferences of individuals and ensure sufficient provision of the topics of relevance.

It is interesting to consider the extent to which such provision is delivered through paid-for channels. In several countries, some public sector provision is fee-based (Brazil, Chile, Estonia, Jamaica) or the public sector provides support both with and without a fee, as is the case in Japan. Not-for-profits are less likely to be charging for their services, but there are fees for using this channel in Colombia, Estonia, Kenya and Turkey (although the Estonian response notes that the fee is symbolic, rather than attempting to cover costs of delivery). The business sector most frequently provides paid-for advice, but MSMEs in Bangladesh, China, Colombia and Japan can access some advice from this sector for free.

The financial sector may stand to profit from a strong relationship with potential and existing entrepreneurs, potentially explaining the free provision of advice in countries such as Australia, Bangladesh, China, Estonia, India, Indonesia, Jamaica, Japan, Kenya and Turkey. In some of these countries, entrepreneurs also have the option of paying for advice from within the financial sector; perhaps indicating that a range of information is available, or that the financial services sector includes financial advisors specialising in MSMEs.

Free guidance and mentoring from other entrepreneurs could be a powerful way to deliver financial education that is tailored to the needs of the recipient. However, there is a logistical challenge in matching existing entrepreneurs - who typically have limited free time - with others who wish to learn from them. This challenge has been addressed to some extent in Australia, Bangladesh, Chile, Estonia, Indonesia, Jamaica, Kenya, Serbia and Turkey; and in all but Chile the channel is open to all size of MSME and potential entrepreneurs.

\section{Delivery methods}

Entrepreneurs may wish to access financial education and advice in different formats. Each format has its own strengths and is likely to appeal more or less depending on particular circumstances. For example, leaflets may provide useful information that can be easily carried and read whilst waiting for appointments or commuting, whilst online courses are beneficial when they can be accessed out of office hours (subject to having the necessary equipment and connectivity). Various other forms of digital delivery method also provide flexible, appealing methods of providing small pieces of information or guidance. For example 
mobile applications and social media platforms are ideal for 'bite-sized' information delivery, whilst the traditional media (including TV, radio and magazines) provides an opportunity to reach out to large numbers of people relatively quickly with a message that is more nuanced and engaging (see OECD, $2017 \mathrm{~d}$ for further examples).

Leaflets and other printed materials are the most common delivery method for financial education for MSMEs among the responding countries. All sizes of enterprise are targeted in this way in Australia, Bangladesh, Brazil, China, Estonia, Indonesia, Jamaica, Kenya and Serbia. In other responding countries this approach is only used to reach certain types of enterprise.

Online courses and information are less widely available, but are nevertheless provided to some enterprises in Australia, Brazil, Colombia, Estonia, Italy, Jamaica, Serbia, Spain and Turkey. Similarly, mobile applications are not a common tool for delivery to the target group of potential entrepreneurs and MSMEs. However some information is available through this approach in Australia, Brazil, Chile, Indonesia and Turkey; in Chile the applications are designed for use by small business owners.

Social media is a relatively new way of accessing target groups. In some countries specific groups of entrepreneurs may be created online, or big data type analytics could be used to identify individuals on social media platforms that are likely to be entrepreneurs; alternatively more straightforward marketing tools may be used in the hope of reaching some of the target population. Social media delivery is available in Australia, Bangladesh, Chile, China, Estonia, Indonesia, Japan and Kenya.

More traditional types of media such as TV or magazines are used to deliver financial education to MSMEs in just 7 countries responding to the stocktake questionnaire. Several countries reported that none of the delivery methods listed is used to reach MSMEs. These include Denmark, India, Romania and Slovenia. Just one approach is used in Hong Kong, China (printed); Italy; and Spain (online).

Table 10. Delivery channels and methods used for financial education

\begin{tabular}{|c|c|c|c|c|c|c|c|c|c|}
\hline \multirow[b]{2}{*}{ Country } & \multicolumn{9}{|c|}{ 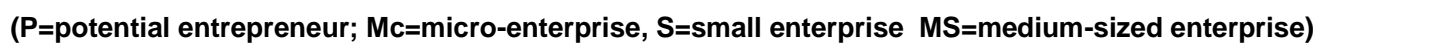 } \\
\hline & 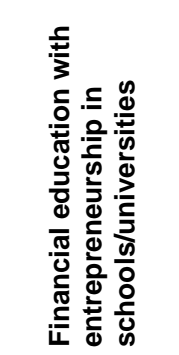 & 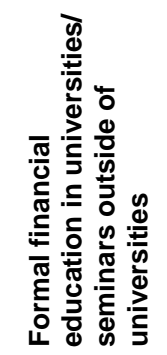 & 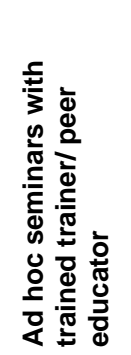 & 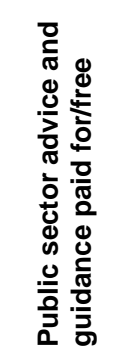 & 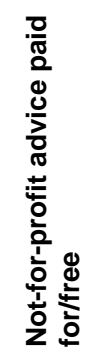 & 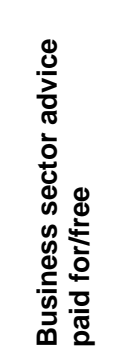 & 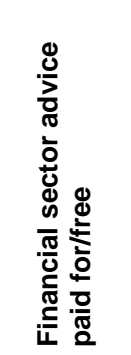 & 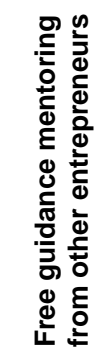 & 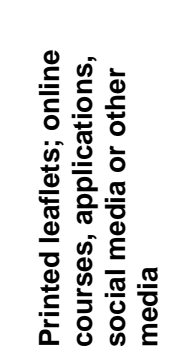 \\
\hline Australia & Both: $P$ & $\begin{array}{l}\text { Both: (P, } \\
\text { Mc, S, MS) }\end{array}$ & $\begin{array}{l}\text { Both: (P, } \\
\text { Mc, S, } \\
\text { MS) }\end{array}$ & $\begin{array}{l}\text { Free: (P, } \\
\text { Mc, S, } \\
\text { MS) }\end{array}$ & $\begin{array}{l}\text { Free: } \\
(\mathrm{P}, \\
\text { Mc, S, } \\
\text { MS) }\end{array}$ & $\begin{array}{l}\text { Both: (P, } \\
\text { Mc, S, } \\
\text { MS) }\end{array}$ & $\begin{array}{l}\text { Both: (P, } \\
\text { Mc, S, } \\
\text { MS) }\end{array}$ & $\begin{array}{l}\mathrm{P}, \mathrm{Mc} \\
\mathrm{S}, \mathrm{MS}\end{array}$ & $\begin{array}{l}\text { All: (P, Mc, S, } \\
\text { MS) }\end{array}$ \\
\hline Bangladesh & $\begin{array}{l}\text { Universities: } \\
\text { P }\end{array}$ & $\begin{array}{l}\text { Both: (P, } \\
\text { Mc, S, MS) }\end{array}$ & No & $\begin{array}{l}\text { Free: (P, } \\
\text { Mc, S, } \\
\text { MS) }\end{array}$ & $\begin{array}{l}\text { Free: } \\
\text { (P, } \\
\text { Mc, S, } \\
\text { MS) }\end{array}$ & $\begin{array}{l}\text { Free: (P, } \\
\text { Mc, S, } \\
\text { MS) }\end{array}$ & $\begin{array}{l}\text { Free: (P, } \\
\text { Mc, S, } \\
\text { MS) }\end{array}$ & $\begin{array}{l}\mathrm{P}, \mathrm{Mc} \\
\mathrm{S}, \mathrm{MS}\end{array}$ & $\begin{array}{l}\text { Leaflets, } \\
\text { social media, } \\
\text { other media: } \\
\text { (P, Mc, S, } \\
\text { MS) }\end{array}$ \\
\hline Brazil & $\begin{array}{l}\text { Universities: } \\
\mathrm{P}\end{array}$ & $\begin{array}{l}\text { Outside: (P, } \\
\text { Mc) }\end{array}$ & no & $\begin{array}{l}\text { Both: (P, } \\
\text { Mc, S) }\end{array}$ & $\begin{array}{l}\text { Free: } \\
\text { (P, } \\
\text { Mc, S) }\end{array}$ & $\begin{array}{l}\text { Paid for: } \\
\text { (P, Mc, } \\
\text { S, MS) }\end{array}$ & $\begin{array}{l}\text { Both: (P, } \\
\text { Mc, S, } \\
\text { MS) }\end{array}$ & no & $\begin{array}{l}\text { All except } \\
\text { social media: } \\
\text { (P, Mc, S, and } \\
\text { MS except } \\
\text { other media) }\end{array}$ \\
\hline
\end{tabular}




\begin{tabular}{|c|c|c|c|c|c|c|c|c|c|}
\hline \multirow[b]{2}{*}{ Country } & \multicolumn{9}{|c|}{ ( $\mathrm{P}=$ potential entrepreneur; $\mathrm{Mc}=$ micro-enterprise, $\mathrm{S}=$ small enterprise $\mathrm{MS}=$ medium-sized enterprise) } \\
\hline & 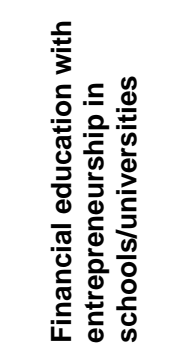 & 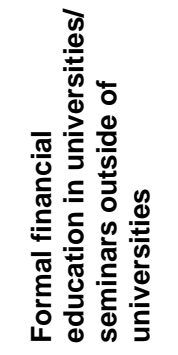 & 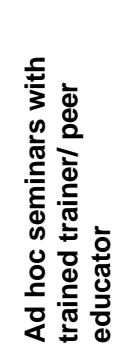 & 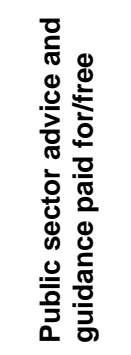 & 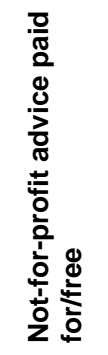 & 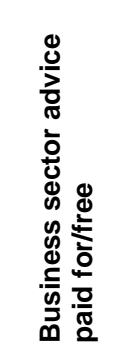 & 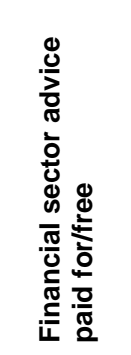 & 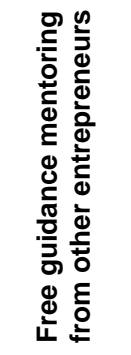 & 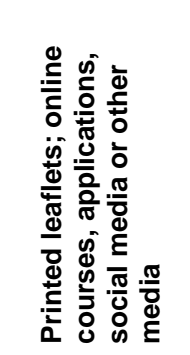 \\
\hline Chile & no & $\begin{array}{l}\text { In } \\
\text { universities } \\
(\mathrm{P}, \mathrm{Mc}, \mathrm{S}, \\
\text { MS); outside } \\
(\mathrm{Mc}, \mathrm{S})\end{array}$ & $\begin{array}{l}\text { Trained } \\
\text { (P, Mc, } \\
\text { S, MS); } \\
\text { Peer } \\
\text { (Mc, S) }\end{array}$ & $\begin{array}{l}\text { Paid for: } \\
\text { (Mc) }\end{array}$ & no & $\begin{array}{l}\text { Paid: (S, } \\
\text { MS) }\end{array}$ & $\begin{array}{l}\text { Paid: } \\
\text { (Mc); } \\
\text { Free: (P, } \\
\text { Mc, S) }\end{array}$ & $\mathrm{P}, \mathrm{Mc}, \mathrm{S}$ & $\begin{array}{l}\text { Leaflets and } \\
\text { online } \\
\text { courses (Mc, } \\
\text { S); } \\
\text { applications } \\
\text { (S); Social } \\
\text { media: (P, } \\
\text { Mc, S); other } \\
\text { media (S, } \\
\text { MS) }\end{array}$ \\
\hline China & $\begin{array}{l}\text { Universities: } \\
\text { P }\end{array}$ & $\begin{array}{l}\text { Both: (S, } \\
\text { MS) }\end{array}$ & no & $\begin{array}{l}\text { Free: (P, } \\
\text { Mc, S, } \\
\text { MS) }\end{array}$ & $\begin{array}{l}\text { Free: } \\
(\mathrm{P}, \\
\text { Mc, S, } \\
\text { MS) }\end{array}$ & $\begin{array}{l}\text { Free: }(P, \\
\text { Mc, S, } \\
\text { MS) }\end{array}$ & $\begin{array}{l}\text { Free: (P, } \\
\text { Mc, S, } \\
\text { MS) }\end{array}$ & no & $\begin{array}{l}\text { Printed, social } \\
\text { media, other } \\
\text { media (P, Mc, } \\
\mathrm{S}, \mathrm{MS})\end{array}$ \\
\hline Colombia & no & no & no & $\begin{array}{l}\text { Free: }(P, \\
\text { Mc) }\end{array}$ & $\begin{array}{l}\text { Paid } \\
\text { for: (P, } \\
M c)\end{array}$ & $\begin{array}{l}\text { Free: }(P, \\
M c)\end{array}$ & no & no & $\begin{array}{l}\text { Printed, } \\
\text { online; other } \\
\text { media }(P, M c)\end{array}$ \\
\hline Denmark & $\begin{array}{l}\text { Universities: } \\
\text { P }\end{array}$ & $\begin{array}{l}\text { Universities: } \\
\text { (P, Mc, S, } \\
\text { MS) }\end{array}$ & no & $\begin{array}{l}\text { Free: (P, } \\
\text { Mc, S, } \\
\text { MS) }\end{array}$ & no & no & no & no & no \\
\hline Estonia & Both: P & $\begin{array}{l}\text { Both: (P, } \\
\text { Mc, S, MS) }\end{array}$ & $\begin{array}{l}\text { Peer: }(P, \\
\text { Mc) }\end{array}$ & $\begin{array}{l}\text { Paid for: } \\
(P) ; \\
\text { Free: (P, } \\
\text { Mc, S, } \\
\text { MS) }\end{array}$ & $\begin{array}{l}\text { Paid } \\
\text { for: (P, } \\
\text { Mc, S, } \\
\text { MS) }\end{array}$ & $\begin{array}{l}\text { Both: (P, } \\
\text { Mc, S, } \\
\text { MS) }\end{array}$ & $\begin{array}{l}\text { Free: (P, } \\
\text { Mc, S, } \\
\text { MS) }\end{array}$ & $\begin{array}{l}\mathrm{P}, \mathrm{Mc} \\
\mathrm{S}, \mathrm{MS}\end{array}$ & $\begin{array}{l}\text { Printed: (P, } \\
\text { Mc, S, MS); } \\
\text { online: (S), } \\
\text { social media: } \\
\text { P, Mc, S, MS }\end{array}$ \\
\hline $\begin{array}{l}\text { Hong Kong, } \\
\text { China }\end{array}$ & Schools: $(P)$ & $\begin{array}{l}\text { Outside: (P, } \\
\text { Mc, S) }\end{array}$ & $\begin{array}{l}\text { Trained: } \\
(\mathrm{P})\end{array}$ & $\begin{array}{l}\text { Free: (P, } \\
\text { Mc, S, } \\
\text { MS) }\end{array}$ & $\begin{array}{l}\text { Free: } \\
(\mathrm{P}, \\
\mathrm{Mc})\end{array}$ & no & no & no & $\begin{array}{l}\text { Printed: (P, } \\
M c)\end{array}$ \\
\hline India & $\begin{array}{l}\text { Universities: } \\
\text { (P) }\end{array}$ & $\begin{array}{l}\text { Both: (P, } \\
\text { Mc, S, MS) }\end{array}$ & $\begin{array}{l}\text { Trained: } \\
\text { (P, Mc, } \\
\text { S, MS) }\end{array}$ & $\begin{array}{l}\text { Free: }(P, \\
\text { Mc, S, } \\
\text { MS) }\end{array}$ & no & no & $\begin{array}{l}\text { Free: }(P, \\
\text { Mc, S, } \\
\text { MS) }\end{array}$ & no & no \\
\hline Indonesia & Both: (P) & $\begin{array}{l}\text { Universities: } \\
\text { (P, Mc, S, } \\
\text { MS) }\end{array}$ & $\begin{array}{l}\text { Both: (P, } \\
\text { Mc, S, } \\
\text { MS) }\end{array}$ & $\begin{array}{l}\text { Free: (P, } \\
\text { Mc, S, } \\
M S)\end{array}$ & $\begin{array}{l}\text { Free: } \\
(\mathrm{P}, \\
\text { Mc, S, } \\
\text { MS) }\end{array}$ & & $\begin{array}{l}\text { Free: (P, } \\
\text { Mc, S, } \\
\text { MS) }\end{array}$ & $\begin{array}{l}\mathrm{P}, \mathrm{Mc} \\
\mathrm{S}, \mathrm{MS}\end{array}$ & $\begin{array}{l}\text { Printed, } \\
\text { applications, } \\
\text { social media: } \\
\text { (P, Mc, S, } \\
\text { MS) }\end{array}$ \\
\hline Italy & no & $\begin{array}{l}\text { Outside: (S, } \\
\text { MS) }\end{array}$ & no & no & no & no & no & 0 & $\begin{array}{l}\text { Online: (S, } \\
\text { MS) }\end{array}$ \\
\hline Jamaica & $\begin{array}{l}\text { Universities: } \\
(P)\end{array}$ & $\begin{array}{l}\text { Both: (P, } \\
\text { Mc, S, MS) }\end{array}$ & $\begin{array}{l}\text { Both: (P, } \\
\text { Mc, S, } \\
\text { MS) }\end{array}$ & $\begin{array}{l}\text { Both: (P, } \\
\text { Mc, S, } \\
\text { MS) }\end{array}$ & no & $\begin{array}{l}\text { Paid for: } \\
\text { (P, Mc, } \\
\text { S, MS) }\end{array}$ & $\begin{array}{l}\text { Free: }(P, \\
\text { Mc, S, } \\
\text { MS) }\end{array}$ & $\begin{array}{l}\mathrm{P}, \mathrm{Mc} \\
\mathrm{S}, \mathrm{MS}\end{array}$ & $\begin{array}{l}\text { Printed, } \\
\text { online: (P, } \\
\text { Mc, S, MS) }\end{array}$ \\
\hline Japan & Both: (P) & $\begin{array}{l}\text { Universities: } \\
(\mathrm{P}, \mathrm{Mc}, \mathrm{S} \text {, } \\
\mathrm{MS})\end{array}$ & $\begin{array}{l}\text { Trained: } \\
\text { (Mc, S, } \\
\text { MS) }\end{array}$ & $\begin{array}{l}\text { Both: (P, } \\
\text { Mc, S, } \\
\text { MS) }\end{array}$ & & $\begin{array}{l}\text { Both: (P, } \\
\text { Mc, S, } \\
\text { MS) }\end{array}$ & $\begin{array}{l}\text { Both: (P, } \\
\text { Mc, S, } \\
\text { MS) }\end{array}$ & & $\begin{array}{l}\text { Printed: (Mc, } \\
\text { S, MS); social } \\
\text { media: (P, } \\
\text { Mc, S, MS) }\end{array}$ \\
\hline Kenya & Both: (P) & $\begin{array}{l}\text { Both: (P, } \\
\text { Mc, S, MS) }\end{array}$ & $\begin{array}{l}\text { Both: }(P, \\
\text { Mc, S, } \\
\text { MS) }\end{array}$ & no & $\begin{array}{l}\text { Both: } \\
\text { (P, } \\
\text { Mc, S, } \\
\text { MS) }\end{array}$ & $\begin{array}{l}\text { Both: (P, } \\
\text { Mc, S, } \\
\text { MS) }\end{array}$ & $\begin{array}{l}\text { Both: (P, } \\
\text { Mc, S, } \\
\text { MS) }\end{array}$ & $\begin{array}{l}\mathrm{P}, \mathrm{Mc} \\
\mathrm{S}, \mathrm{MS}\end{array}$ & $\begin{array}{l}\text { Printed, social } \\
\text { media and } \\
\text { other media: } \\
(\mathrm{P}, \mathrm{Mc}, \mathrm{S} \text {, } \\
\text { MS) }\end{array}$ \\
\hline
\end{tabular}




\begin{tabular}{|c|c|c|c|c|c|c|c|c|c|}
\hline \multirow[b]{2}{*}{ Country } & \multicolumn{9}{|c|}{ 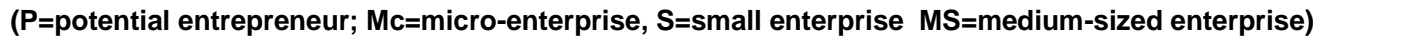 } \\
\hline & 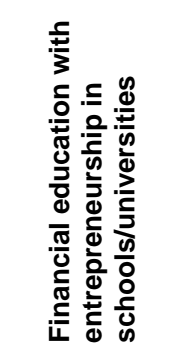 & 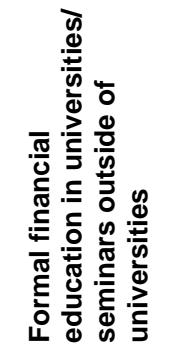 & 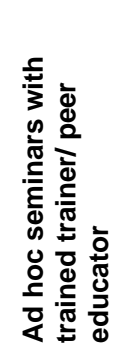 & 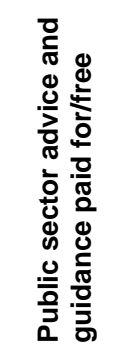 & 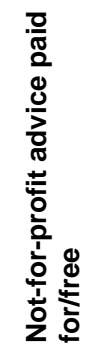 & 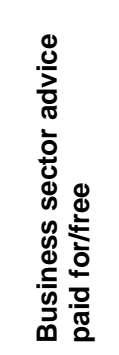 & 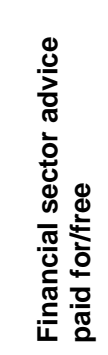 & 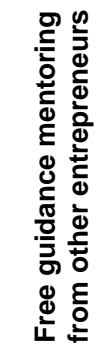 & 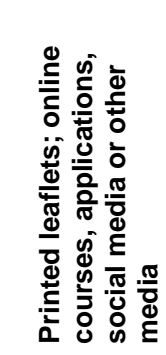 \\
\hline Portugal & Both: $(P)$ & no & $\begin{array}{l}\text { Trained: } \\
\text { (P, Mc, } \\
\mathrm{S}, \mathrm{MS})\end{array}$ & $\begin{array}{l}\text { Free: (P, } \\
\text { Mc, S, } \\
\text { MS) }\end{array}$ & $\begin{array}{l}\text { Paid: } \\
\text { (P, } \\
\text { Mc, S, } \\
\text { MS) }\end{array}$ & no & no & no & $\begin{array}{l}\text { Printed, } \\
\text { online, } \\
\text { applications, } \\
\text { social media } \\
\text { and other } \\
\text { media: (P, } \\
\text { Mc, S, MS) }\end{array}$ \\
\hline Romania & Both: (P) & Both: $(P)$ & no & no & $\begin{array}{l}\text { Free: } \\
\text { (P, } \\
\text { Mc, S, } \\
\text { MS) }\end{array}$ & no & no & no & no \\
\hline Serbia & Both: $(P)$ & $\begin{array}{l}\text { Universities: } \\
\text { (P, Mc, S, } \\
\text { MS); outside } \\
\text { (Mc) }\end{array}$ & no & no & no & no & no & $\begin{array}{l}\mathrm{P}, \mathrm{Mc} \\
\mathrm{S}, \mathrm{MS}\end{array}$ & $\begin{array}{l}\text { Printed: (P, } \\
\text { Mc, S, MS), } \\
\text { online: (P, } \\
\text { Mc) }\end{array}$ \\
\hline Slovenia & Schools: $(\mathrm{P})$ & no & no & no & no & no & no & no & no \\
\hline Spain & no & $\begin{array}{l}\text { Outside: (P, } \\
\text { Mc, S, MS) }\end{array}$ & $\begin{array}{l}\text { Trained: } \\
\text { (M, S, } \\
\text { MS) }\end{array}$ & no & no & no & no & no & $\begin{array}{l}\text { Online: (P, } \\
\text { Mc, S, MS) }\end{array}$ \\
\hline Turkey & Both: $(P)$ & $\begin{array}{l}\text { Both: (P, } \\
\text { Mc, S, MS) }\end{array}$ & no & no & $\begin{array}{l}\text { Paid } \\
\text { for: } \\
\text { (Mc, } \\
\text { S, MS) }\end{array}$ & $\begin{array}{l}\text { Paid for: } \\
\text { (P, Mc, } \\
\text { S, MS) }\end{array}$ & $\begin{array}{l}\text { Free: } \\
\text { (Mc, S, } \\
\text { MS) }\end{array}$ & $\begin{array}{l}\mathrm{P}, \mathrm{Mc} \\
\mathrm{S}, \mathrm{MS}\end{array}$ & $\begin{array}{l}\text { Online and } \\
\text { applications: } \\
\text { (Mc, S, MS) }\end{array}$ \\
\hline
\end{tabular}

Responses to stocktake. Responding countries not listed had limited or no information for this section; similarly empty cells indicate that the information was not available.

\section{Evidence of effectiveness}

The stocktake included a section to explore the evidence of effectiveness of financial education for MSMEs. It is striking that programmes are not being robustly evaluated at the moment. This possibly reflects the lack of measurement tools. However, given the intended policy aims of financial education, it should be possible to monitor progress in other ways in order to indicate whether a strategy or initiative is making a difference. Empirical evidence and available studies on the effectiveness of financial education and business training programmes are quite fragmented, with most of the evidence focused on specific parts of the MSME population and with a high heterogeneity in definitions and methodology applied.

A structural model tested on data from young entrepreneurs in Canada who received start-up loans through their participation in the Canadian Youth Business Foundation showcases the impact of financial literacy on new venture survival (Wise, 2013). According to the study, increased financial literacy skills lead to more frequent generation of financial statements, which in turn increases the likelihood of loan repayment and decreases the probability of venture failure. Similarly, lower default rates were partly explained by the training that borrowers had received and which enabled them to better understand the optimal utilisation of loan funds (Bichanga and Aseyo, 2013). 
The effectiveness and efficiency of support service public programmes (finance, non-financial assistance or a combination of both) has been evaluated in the European Union, with clear evidence on the effectiveness of non-financial support such as business advice, and the contribution of combined financial and non-financial support in one package (EC, 2013b). The study showed that most strikingly successful measures were those that targeted not just capital market failures, but information market failures. Particularly for medium-sized enterprises, innovation support, networking and innovation consortia proved effective at increasing long-term growth and productivity. For small and micro enterprises, basic business advice was proved to be potentially the single most cost-effective form of support.

A study assessing the effectiveness of the EGF financial literacy programme on the performance of MSMEs in the Njoro District in Kenya found that there was a significant improvement in revenue performance of MSMEs participating in the financial literacy programme (Siekei et al., 2013). The programme emphasized on budgeting, financial analysis, credit management and book keeping skills. Credit management skills obtained through the financial literacy programme enhanced the MSME performance through acquisition of credit financing and better management of their loan portfolios. Budgeting skills had an impact in growing sales, profits and ensuring smooth running of the business, enhancing the overall business performance.

Premaud et al. (2012) studied a group of 1,500 young entrepreneurs who took part in an entrepreneurship track instead of academic track in the final year of university, arguing that such training leads to a $6 \%$ increase in self-employment rates for males and 3 percent for females one year later. A number of different studies on the impact of training on business profitability and growth through a change of business practices find a positive effect of business training on business practices, although studies differ in the specific practices they measure, how comprehensively they measure them, and how (if at all) they aggregate them (McKenzie and Woodruff, 2012). It should be noted, however, that financial literacy is a necessary but not sufficient condition for the better financial management; irrespective of the level of financial literacy of a potential entrepreneur, if there is no funding availability then the perspectives of the company are gloomier.

Meta-analyses of the effects of entrepreneurship education and training find a correlation with improved incomes (Cho and Honorati 2013), noting at the same time a lack of rigour in some of the evaluations examined. The literature shows also some mixed results, and further research will be necessary to understand whether the evaluation method itself made it difficult to capture positive outcomes, or whether certain aspects of the programme need changing.

Initiatives targeting specific sub-groups of the MSME population, such as the Usaha Wanita in Indonesia and the SEWA Bank's training programmes for women entrepreneurs in India highlight the effectiveness of designing financial education programmes with the specific needs and preferences of the sub-group in mind. The same holds for similar programmes targeting the specific needs of other subgroups of the MSME population, including young entrepreneurs, unemployed, migrants or other minorities.

In a review of meta-evaluations and impact evaluations during the period 2010 to 2014, the International Labor Organization's Women's Entrepreneurial Development (ILO-WED) Programme identified that a common characteristic of effective programmes for women entrepreneurs was a holistic approach incorporating a combination of financial literacy education together with business training, mentoring, peer support and follow up assistance.

In Sri Lanka, a team of researchers evaluated the impact of the International Labour Organization's (ILO) Start and Improve Your Business (SIYB) training programme (De Mel et al., 2014). SIYB is designed for micro and small scale enterprises in developing countries and has reached 6 million trainees, 
been translated into 40 languages and introduced in over 100 countries. The programme was conducted with a non-profit training institution, the Sri Lanka Business Development Centre involving 1,256 programme participants. The evaluation sought to examine the impact of the business skills training compared to a combination of training and a cash grant on two groups of women: existing enterprise owners and those interested in establishing a business. The evaluation found that for existing business owners, the training programme improved business practices but had no effect on profits or sales. When provided with a grant however, increases in business profitability were observed but only in the short term. For potential entrepreneurs, the training resulted in faster start-up of businesses and improved profitability. The researchers concluded that skills training may be more effective for new business owners and that it was easier to help women entrepreneurs establish new businesses than to improve the growth of existing businesses. 


\section{Section IV. Emerging findings and policy guidance}

Important prerequisites and enabling factors for the healthy development of MSMEs globally include an economically sound and business-friendly environment, certainty of regulatory conditions, a stable tax framework and the supporting of a diverse range of financing instruments, as described by the G20/OECD High-level Principles on SME Financing (OECD, 2015d).

In addition to these prerequisites, this paper has highlighted a number of challenges that impede the creation and growth of MSMEs including those related to their access to finance and low levels of financial literacy, and provided practical examples of policies and trends already in place in a number of countries.

Based on the above analysis, and as a complement to efforts already in place or planned, more specific policy guidance is suggested. This is in line with the broader guidance provided by the OECD/INFE High-level Principles on National Strategies for Financial Education, and drawing on the lessons learned in the OECD/INFE Policy Handbook on National Strategies. This guidance particularly relates to the need for robust evidence, the coordination of stakeholder efforts, the importance of identifying specific target audiences and the identification and use of relevant delivery mechanisms, as discussed below.

\section{Evidence}

The first steps for policy makers seeking to support and improve the level of financial literacy among MSMEs are to consider whether the current provision is universally accessible and co-ordinated and collect solid evidence on the levels of financial literacy among MSMEs. In particular, it is important to:

1. Map current initiatives targeting MSMEs, their delivery channels and the stakeholders involved and assess their organisation and efficiency to identify the extent to which MSMEs and potential entrepreneurs have access to high-quality financial education that can support the creation, development and growth of enterprises;

2. Measure the financial literacy levels of different kinds of MSMEs and assess their needs in order to identify the parts of the MSME population in greater need of financial education action and the areas requiring focused attention; and

3. Evaluate the efficacy and impact of financial education programmes targeting MSMEs so as to address the deficit of evidence around the impact of financial education on the performance of SMEs.

\section{Coordination}

It is important to ensure coordination among stakeholder organisations with good access to MSMEs and to conduct financial education through such stakeholders. This should seek to streamline the typically fragmented delivery of financial education initiatives provided by the different stakeholders involved in the support of MSMEs. This can be achieved by: 
1. Introducing an institutional framework of MSME financial education action within the governance mechanism of the National Strategy for Financial Education, where one exists; or

2. If no co-ordinated approach to financial education exists policy makers could consider including financial education for MSMEs within another relevant policy framework such as a framework for financial inclusion or entrepreneurship.

\section{Target audiences}

MSMEs include a diverse range of players, making it imperative that programmes designed to support them are tailored to the specific needs of particular types of entrepreneur. This can be achieved by:

1. Promoting and supporting a targeted, tailored approach, adapted to address the specific needs of particular segments of the MSME population and make any financial education action easily accessible by the targeted sub-group;

2. Differentiating the approach based on the size of the MSME and its stage in the MSME life cycle, as well as levels of financial literacy;

3. Considering the needs of formal and informal MSMEs where relevant;

4. Ensuring that the design and delivery of financial education adequately addresses the particular needs and preferences of specific target groups such as women, young entrepreneurs, unemployed potential entrepreneurs, migrants or other minorities wishing to engage in entrepreneurial activity; and

5. Developing appropriate content that addresses issues specific to small businesses, including access to finance, but also topics such as cash flow management, pension planning, business planning, insurance, investment and other relevant fields.

\section{Delivery mechanisms}

A range of possible delivery mechanisms should be explored to reach as many MSMEs as possible. It is important to ensure that delivery channels are suitable for the specific needs and constraints of MSMEs and potential entrepreneurs, to explore the potential of technology as an enabling mechanism and communication tool (e.g. online portals, webinars) and to make financial education a solid part of "onestop-shops" for SME support, where these exist (e.g. "How-to" guides and other user-friendly information). In this regard, it could be beneficial to:

1. Combine financial education with access, in order to maximise the effectiveness and efficiency of financial education action;

2. Consider making the deployment of financial education programmes by private financial institutions/banks a pre-requisite for their eligibility as intermediaries for the disbursement of public support financing to MSMEs (e.g. credit guarantees, direct lending). The involvement of private financial institutions (banks) should be designed and monitored along the lines of the Guidelines for Private and Not-for-profit Stakeholders in Financial Education ${ }^{8}$, in order to avoid conflicts of interest;

\footnotetext{
8 As developed by the OECD/INFE in the context of its work on National Strategies for Financial Education.
} 
3. Leverage the expertise and one-to-one mentoring capabilities and capacity building of financial services providers (financial advisors, banks, accountants, capital market advisors, insurance or pension markets advisors) and their associations for the delivery of financial education programmes;

4. Consider making the attendance of financial education programmes by MSMEs a pre-requisite for their eligibility as receivers of public financing support schemes;

5. Support clusters and networks of MSMEs and potential entrepreneurs not only as a channel for the delivery of financial education programmes, but also as a natural environment for knowledge transfer and diffusion, capacity building and mentoring; and

6. Stay abreast of technical innovations that may help to provide access to finance for MSMEs and/or enhance financial education delivery and ensure that all stakeholders are made aware of developments and properly reflect them in programmes and initiatives.

\section{Future work}

The findings above reinforce the need for policy tools to address the financial education needs of MSMEs. The OECD/INFE is currently working on a core competencies framework for this group which will be used to develop a specific measurement tool that can be used to provide evidence of the needs of particular groups within the MSME population. 


\section{References}

Andrews, D., A. Caldera Sanchez and A. Johansson (2011), Towards a better understanding of the informal economy. Economics Department Working Papers No. 873. OECD www.oecd.org/eco/workingpapers

Atkinson, A., F. Messy, L. Rabinovich and J. Yoong (2015), Research and Literature on Financial Education for Long-term Savings and Investments, OECD Working Papers on Finance, Insurance and Private Pensions, No. 39, OECD Publishing. http://dx.doi.org/10.1787/5jrtgzfl6g9w-en

Basel Committee on Banking Supervision - BCBS (2016), Revisions to the securitisation framework, July. www.bis.org/bcbs/publ/d374.pdf

Berger, A. and G. Udell (1998), The economics of small business finance: The roles of private equity and debt markets in the financial growth cycle, Journal of Banking \& Finance 22 (1998) 613-673.

Bichanga, W. O., and L. Aseyo (2013), Causes of Loan Default within Micro Finance Institutions in Kenya, Interdisciplinary Journal of Contemporary Research in Business, 4(12), 316-335.

Chartered Institute of Personnel and Development (2012), Workplace Financial Education, CIPD Policy Reports, www.cipd.co.uk/binaries/workplace-financial-education_2012.pdf.

Cho, W. and M. Honorati (2013), Entrepreneurship Programs in Developing Countries, A Meta Regression Analysis, Policy Research Working Paper 6402, World Bank, April.

De Carolis, D., B. Litzky and K. Eddleston (2009), Why networks enhance the progress of new venture creation: The influence of social capital and cognition, Entrepreneurship Theory and Practice, 33(2), 527-545. http://dx.doi.org/10.1111/j.1540-6520.2009.00302.x

Drexler, A., G. Fischer and A. Schoar (2010), Keeping it simple: Financial literacy and rules of thumb, Centre for Economic Policy Research Discussion Paper 7994.

European Commission (2015), Proposal for a Regulation of the European Parliament and the Council amending Regulation (EU) No 575/2013 on prudential requirements for credit institutions and investment firms. http://eur-lex.europa.eu/legal-content/EN/TXT/?uri=CELEX:52015PC0473

European Commission (2013a), Results of the public consultation on the top 10 most burdensome legislative acts for SMEs.

European Commission (2013b), Regional policy for smart growth of SMEs, European Commission, Directorate-General for Regional and Urban policy, August.

European Commission (2007), Models to reduce the disproportionate regulatory burden of SMEs, Report of the Expert Group, Enterprise and Industry Directorate-General. 
Global Entrepreneurship Monitor (2009), Global Report 2008, N. S. Bosma, Z. J. Acs, E. Autio, A. Coduras, J. Levie, and Global Entrepreneurship Research Consortium (GERA).

International Organization of Securities Commissions - IOSCO (2015), Statement on Addressing Regulation of Crowdfunding, December. www.iosco.org/library/pubdocs/pdf/IOSCOPD521.pdf

McKenzie, D. and C. Woodruff (2012), What are we Learning from Business Training and Entrepreneurship Evaluations around the Developing World?, IZA Discussion Paper No. 6895, October, No. 6895.

Miller, M. (Ed.) (2003), Credit Reporting Systems and the International Economy, MIT Press.

Ministry of Cooperatives and Small and Medium Enterprises (Kementerian Koperasi Dan Usaha Kecil Dan Menengah), (2013), Indonesia data portal. www.depkop.go.id/berita-informasi/data-informasi/dataumkm/ (in Bahasa).

Nassr, I. K., V. Robano and G. Wehinger (2016), Unleashing the Export Potential of SMEs in Greece, OECD Working Papers on Finance, Insurance and Private Pensions, No. 41, OECD Publishing, Paris. http://dx.doi.org/10.1787/5jm0qgt464f6-en

Nassr, I.K. and G. Wehinger (2015a), Unlocking SME finance through market-based debt: Securitisation, private placements and bonds, OECD Journal: Financial Market Trends vol. 2014/2. http://dx.doi.org/10.1787/fmt-2014-5js3bg1g53ln

Nassr, I.K. and G.Wehinger (2015b), Opportunities and Limitations of Public Equity Markets for SMEs, OECD Journal: Financial Market Trends, Vol. 2015/1/. http://dx.doi.org/10.1787/fmt-20155jrs051fvnjk

Nassr, I.K. and G. Wehinger (2014), Non-bank debt financing for SMEs: The role of securitisation, private placements and bonds. Discussions at an OECD Financial Roundtable, OECD Journal: Financial Market Trends, Vol. 2014/1. http://dx.doi.org/10.1787/fmt-2014-5jxx05svvw34

OECD (2017a), Financial education for micro, small and medium-sized enterprises in Asia. www.oecd.org/finance/Financial-education-for-MSMEs-in-Asia.pdf

OECD (2017b), Small, Medium, Strong.Trends in SME Performance and Business Conditions, OECD Publishing, Paris. http://dx.doi.org/10.1787/9789264275683-en

OECD (2017c), Financing SMEs and Entrepreneurs 2016: An OECD Scoreboard, OECD Publishing, Paris. http://dx.doi.org/10.1787/fin sme ent-2017-en

OECD (2017d), G20/OECD INFE Report on ensuring financial education and consumer protection for all in the digital age. www.oecd.org/finance/g20-oecd-report-on-ensuring-financial-education-andconsumer-protection-for-all-in-the-digital-age.htm

OECD (2016), Entrepreneurship at a Glance 2016, OECD Publishing, Paris http://dx.doi.org/10.1787/entrepreneur_aag-2016-en

OECD (2015a), Opportunities and Constraints of Market-Based Financing for SMEs, OECD Report to G20 Finance Ministers and Central bank Governors, September 2015. www.oecd.org/g20/meetings/antalya/Opportunities-and-Constraints-of-Market-based-Financing-for$\underline{\text { SMEs.pdf }}$ 
OECD (2015b), Entrepreneurship at a Glance 2015, OECD Publishing, Paris. http://dx.doi.org/10.1787/entrepreneur_aag-2015-en

OECD (2015c), New Approaches to SME and Entrepreneurship Financing: Broadening the Range of Instruments, available at www.oecd.org/cfe/smes/New-Approaches-SME-full-report.pdf

OECD (2015d), G20/OECD High Level Principles on SME Financing, OECD Progress Report to G20 Finance Ministers and Central Bank Governors, September 2015. www.oecd.org/finance/privatepensions/G20-OECD-High-level-Principles-on-SME-Financing-Progress-Report.pdf

OECD (2015e), Taxation of SMEs in OECD and G20 Countries, OECD Tax Policy Studies, No. 23, OECD Publishing, Paris. http://dx.doi.org/10.1787/9789264243507-en

OECD/INFE (2015a), OECD/INFE Toolkit to measure financial literacy and financial inclusion. www.oecd.org/daf/fin/financialeducation/2015 OECD INFE Toolkit Measuring_Financial Litera cy.pdf

OECD/INFE (2015b), National Strategies for Financial Education: OECD/INFE Policy Handbook. www.oecd.org/finance/national-strategies-for-financial-education-policy-handbook.htm

OECD/INFE (2014), Guidelines for private and not-for-profit stakeholders in financial education. www.oecd.org/daf/fin/financial-education/OECD-INFE-Principles-National-Strategies-FinancialEducation.pdf

OECD/INFE (2012a), High-level Principles on National Strategies for Financial Education. www.oecd.org/daf/fin/financialeducation/OECD_INFE_High_Level_Principles_National_Strategies Financial Education APEC.pdf

OECD/INFE (2012b), High-level principles for the evaluation of financial education programmes, www.oecd.org/daf/fin/financial-education/49373959.pdf

Premand, P., S. Brodmann, R. Almeida, R. Grun and M. Barouni (2012), Entrepreneurship training and self-employment among university graduates: Evidence from a randomized trial in Tunisia, World Bank Policy Research Working Paper 6285, Impact Evaluation Series No. 77.

Pordata, (2013) Base de Dados Portugal Contemporaneo, data portal (in Portuguese). www.pordata.pt/

Robano, V. (2013), The Role of Public Financial Institutions for SMEs, in Asian Development Bank, ADB-OECD study on enhancing financial accessibility for SMEs: Lessons from recent crises. www.oecd.org/cfe/smes/adb-oecd-study-enhancing-financial-accessibility-smes.pdf.

Siekei, J., Juma Wagoki \& Aquilars Kalio (2013), An Assessment of the role of financial literacy on Performance of Small and Micro Enterprises: Case of Equity Group Foundation Training Program on SMES in Njoro district, Kenya, Journal of Economics \& Finance, VOL.1, No.7

Stiglitz, J. and A. Weiss (1981), Credit rationing in markets with imperfect information, American Economic Review, Vol. 71, No. 3, pp. 393-410.

Wise, S. (2013), The impact of financial literacy on New Venture Survival, International Journal of Business and Management; Vol. 8, No. 23; 2013. 10.5539/ijbm.v8n23p30 


\section{Annex I. Practical examples of country initiatives}

Recognising that financial education for MSMEs is at different stages of development in different countries, Section IV describes a limited number of practical examples of the types of initiatives underway, drawn from responses to the stocktake questionnaire and additional desk research.

\section{Australia}

The Australian Securities and Investments Commission (ASIC) has a website dedicated to financial literacy (MoneySmart); a key part of the Australian national strategy. This targets all Australians, but has specific elements that are of relevance for potential and current entrepreneurs, including a section on YourBusiness. Other stakeholders also manage websites with relevant information, including the Australian Taxation Office, The Department of Industry, Innovation and Science, the Fair Work Ombudsman, the Australian Competition and Consumer Commission and the Australian Small Business Commissioner.

\section{Bangladesh}

Bangladesh does not presently measure the financial literacy levels of MSMEs and potential entrepreneurs, though the Bangladesh Securities and Exchange Commission has recently formed a committee tasked with developing a national policy as part of the country's 10-Year Master Plan. As the target group of this policy is intended to be wide ranging, it is expected to reach MSMEs. It is also yet to be decided whether a policy framework outside of the national strategy will address the financial education needs of MSMEs and potential entrepreneurs and how stakeholders will be involved within such a framework.

\section{Chile}

In Chile the Central Bank, Securities and Insurance Supervisory Agency, National Consumer Service, Technical Cooperation Service, and Banking Supervisory Agency are among the stakeholders providing financial education to MSMEs. BancoEstado, a state-owned enterprise, also has various initiatives at a national level working to reduce gender gaps in access to financial services and entrepreneurship capacities; to provide information regarding financial issues; and to develop, host and maintain a web platform designed to support interaction between entrepreneurs.

\section{China}

In China, general financial literacy content is provided for enterprises of all sizes while the approach for business specific topics varies. Topics on financing opportunities, interacting with and meeting requirements of lenders and investors are provided for enterprises of larger sizes whereas topics on planning and managing business finances and financial risk management are provided for potential entrepreneurs as well as enterprises.

Public sector/government initiatives target all enterprises and potential entrepreneurs at the national level. For example, the People's Bank of China provides financial education for micro, small and mediumsized enterprises and also targets other key groups such as youth, women and the unemployed. Educational institutions and industry organisations focus on providing education for enterprises of all sizes and 
potential entrepreneurs at the local level. Not-for-profit organisations (domestic and international) as well as the financial sector focus on small and medium-sized enterprises at the national level and potential entrepreneurs and micro enterprises at the local level.

\section{Colombia}

The National Learning Service (SENA) in Colombia is an important stakeholder providing national access to formal financial education for MSMEs. The Entrepreneurship Pilot Program, developed by Banca de las Oportunidades also provides valuable formal education in 11 municipalities, focusing on technical assistance for entrepreneurs, entrepreneurial awareness, support in defining the business plan, support and approval of microcredit, as well as training and technical support for up to six months after the start of a business. This project is aimed at low-income entrepreneurs over the age of 18 .

\section{Denmark}

In Denmark the Danish Growth Fund and Regional Growth Houses target micro-enterprises and all businesses, respectively. The Growth Fund provides capital and expertise to new companies, investing equity and providing loans and guarantees in collaboration with private partners and financial institutions. Growth Houses aim to sustain and support the growth of potential start-ups and growth businesses (OECD, 2013).

\section{Estonia}

Estonia has identified a number of specific challenges that hinder the creation of new enterprises and the growth of existing ones. Of particular interest, they recognise that the population identifies potential business ideas but has a low level of business knowledge and so, despite being motivated to increase their income and independence they fail to develop their ideas. As a result, the Ministry of Science and Education has created the Life-long Learning Strategy (2014-2020) to develop different ways of learning that focus more on skills, creativity and entrepreneurial studies. This runs alongside the Ministry of Economic Affairs and Communications' Estonian Businesses Growth Strategy, which aims to raise entrepreneurs' knowledge about business models, development and production, sales and marketing and competitive position. The Ministry of Science and Education also has a special programme called 'Development of entrepreneurship skills and entrepreneurial learning' providing entrepreneurship and financial education, typically through economics lessons.

Other initiatives are run by various private banks and the Tallinn Stock Exchange as well as not-forprofits, peer-groups such as 'Female Investors' and various mentoring services, including that provided by the Enterprise Estonia Agency.

\section{Hong Kong, China}

In Hong Kong, China, occasional training courses are available for young people who may wish to start their own business through the Youth Employment Start service (Y.E.S.). Y.E.S is a personalised service for youth developed by government, with a strong online presence, and includes courses for 'young businessmen'.

Hong Kong, China has a number of initiatives primarily provided by the financial sector and focused on investment related topics, though there is less direct focus on MSMEs or potential entrepreneurs specifically. In the 2015 Review of Financial Education in Hong Kong, China, it was found that of those that had specified a target audience, most focused on students, the elderly and lower income workers. However since these programmes are designed for a board audience, some of them may also be useful for MSMEs and potential entrepreneurs. 


\section{India}

India runs financial literacy camps that aim to reach all types of people. In India this is an effective way to reach potential and current micro-entrepreneurs, since the vast majority work in small businesses or agriculture. The camps provide financial education on budgeting, personal finance, saving and borrowing. MSMEs also have access to information through town hall events. While financial education covers general financial literacy for enterprises of all sizes, business specific content is focused on financing opportunities and intended for enterprises of all sizes.

Stakeholders primarily provide education at the local level and target potential entrepreneurs and enterprises of all sizes. For example, the Reserve Bank of India requires banks to establish financial literacy centres to educate a range of groups including farmers, women, unemployed, senior citizens, youth and micro and small entrepreneurs through financial education camps. The Reserve Bank, recently suggested that each target group should be catered for with a special camp each month to discuss concerns relating to that group. The Reserve Bank also requires centres to provide quarterly reports on their activities in a standardised reporting framework which records the number of participants, the target audience and participating stakeholders. Rural self-employment training institutes also provide entrepreneurship education catering for a range of target groups including MSMEs, youth, women and the unemployed.

In India, several public and private organisations have established institutes which provide training to potential entrepreneurs. The Entrepreneurship Development Institute of India (http://ediindia.org/), a notfor-profit institute sponsored by various financial institutions in India, provides post graduate diplomas aimed at potential entrepreneurs. MSME Development Institute, Mumbai (http://msmedimumbai.gov.in/) under the Ministry of MSME, also provides free and paid consultancy services for business owners. Business owners in rural areas are targeted by the National Institute of Rural Development \& Panchayati Raj (http://www.nird.org.in/) whose training, workshops and seminars aim to improve the knowledge and skills of rural development officials as well as other members of rural communities. The Citi Centre for Financial Literacy (CCFL) operates within the Indian School of Microfinance for Women (ISMW). Initiatives organised by ISMW include programmes for women and other disadvantaged groups as well as train-the-trainer programmes in rural areas.

Whilst it is relatively easy to target micro-entrepreneurs in India, policy makers have found that operating this camp has highlighted the need to develop customised financial education material to address different target groups.

\section{Indonesia}

In Indonesia the financial literacy levels and needs of MSMEs are recognised in policy frameworks. For example, within the Indonesian National Strategy on Financial Literacy, which was launched in 2013, MSMEs are included in the list of target groups for financial education activities/initiatives together with women, students, workers, retirees and professionals residing in both urban and rural areas. Activities within the national strategy include surveys which measure the financial literacy levels of households and therefore cover MSMEs to some extent. A follow up to the first survey in 2013 is has been carried out and is expected to be published in late 2016. The Indonesian Chamber of Commerce and Industry, Kadin Indonesia, also addresses the needs of MSMEs. The financial education needs of this group are also addressed to some extent via other policy frameworks.

Entrepreneurship courses are run for economics students in Indonesia, and ad hoc sessions are provided to business owners with the support of OJK, Bank Indonesia and the Ministry of Cooperatives, among others. In particular, this group of organisations are working to build entrepreneurship skills, 
improve financial literacy and help individuals and business owners to plan and manage their finances. They are reached via focus group discussions, education programmes and websites. Public support microcredit programmes provide assistance and training to MSMEs as part of the funding package so as to ensure that the funds are used for productive purposes. In that context, banks cooperate with the government and in particular with the Ministry of Economy, and are required to provide financial education to MSMEs. Pre- and post-tests indicate that the more detailed delivery method shifted awareness and knowledge and changed behaviour. However, it was not easy to monitor the impact on people in particularly rural locations.

The content of financial education programmes in Indonesia is comparatively broad with coverage of the full list of topics in both the general financial literacy and business literacy categories. This content is provided for enterprises of all sizes except content on understanding the business, financial and economic landscape where the focus is on larger enterprises.

Public sector/government initiatives, financial sector and international not-for-profit organisations are typically involved at the national level and cater to enterprises of all sizes and potential entrepreneurs. For example, OJK provides business support/guidance, entrepreneurial education and general financial education with a focus on micro and small enterprises. Youth, women, migrant workers, instructors and the broader community are also covered. At the local level, the education sector (e.g. universities and colleges) focuses on potential entrepreneurs.

In Indonesia adhoc seminars run by 'trained trainers' and peer educators targeting all enterprise sizes are organised by public authorities such as OJK, Bank Indonesia and the Ministry of Cooperatives and SMEs. For example, seminars for SMEs are held by Konsultan Keuangan Mitra Bank (KKMB), a consortium of public, private and research organisations together with Bank Indonesia.

OJK and Bank of Indonesia have led a number of national financial education initiatives including Ayo ke Bank ("Let's go to the Bank") campaign, SiMOLEK financial education car, Whatever the product, Remember 3 Ps: Ensure benefits, understand the risk, consider costs campaign, Gerakan Indonesia Menabung (National Saving Campaign which also promotes investment) and TabunganKu. Local initiatives include financial education activities held at markets in East Java, Solo, Aceh, Makassar and Kupang. In conjunction with these market events, 'train the trainers' events are organised focusing on MSMEs. Other initiatives by the Ministry of Cooperatives and SMEs are the Pusat Layanan Usaha Terpadu MSME Support Centres in 16 provinces throughout Indonesia. The 42 centres provide services in a range of areas including business consultation, mentoring, assistance in obtaining finance, marketing and promotion, business management training and networking (IFC, 2016).

There are several interesting examples of the use of mobile applications in Indonesia, one of which is, Sikapi Uangmu ("Behave properly with your money") developed by OJK which provides tips, articles and activities on financial management topics. The app also administers mini surveys which are used to measure financial literacy levels of users. Another example is Usaha Wanita, an app developed through a private sector and not-for-profit collaboration.

The Indonesian financial sector is also heavily involved in the provision of financial education due to OJK's requirement that all regulated financial institutions engage in financial education activities that are in line with the national strategy and are not for marketing purposes.

Indonesia has sound evidence on the importance of financial education for MSMEs, with high nonperforming business loans being partly attributed to the lack of awareness of the need to use credit for productive uses. 


\section{Italy}

According to a recent survey conducted by the Bank of Italy together with other authorities and private partners, about 40 of the 107 financial education initiatives for adults held between 2012 and 2014 include enterprises among the target groups. However, only Unicredit developed an initiative at the national level specifically targeted at MSME. The main purpose of Unicredit's intervention is to improve knowledge of financial instruments and bank services, debt management, risk management and the principles of entrepreneurship through face to face education, videos and other materials provided in person and via email.

\section{Japan}

In Japan the Financial Services Agency has a national project providing consultation and advice from regional banks to MSMEs to improve the financial situation of MSMEs. This covers topics such as how to procure funds more easily and how to make business improvement plans and is typically aimed at existing bank clients.

The public sector, industry organisations and the financial sector have provisions at both the national and local levels for potential entrepreneurs and MSMEs. For example:

- The SMRJ cater to the needs of all enterprise sizes and potential entrepreneurs by providing business support guidance, entrepreneurship education and financial education for owners and managers of SMEs.

- The Japan Finance Cooperation (JFC), Japan External Trade Organisation (JETRO), SME revitalisation support councils and consultation centres for business succession provide business support and guidance for all enterprises and potential entrepreneurs. The focus is on helping SMEs to develop their business for global expansion, revitalisation as well as planning for business succession.

- The Japan Chamber of Commerce and Industry also provides business support and guidance for existing enterprises.

- Financial institutions (predominantly banks) provide business support and guidance as well as financial education for enterprises of all sizes. Domestic not-for-profit organisations focus on MSMEs at the national level while educational institutions focus on potential entrepreneurs at the national and local levels. These educational institutions also target youth and the unemployed.

Financial education programmes in Japan are also integrated into the school curriculum with the Central Council for Financial Services Information (CCFSI) providing a detailed outline of financial education topics which are to be taught at the primary, secondary and university levels. The attendants of these programmes are considered to be potential entrepreneurs.

\section{Korea}

In Korea, government agencies such as the Small and Medium Business Corporation, the Small Enterprise and Market Service and the Small Business Training Institute offer educational programmes and consulting support to start-ups, entrepreneurs and MSME employees. A wide range of areas is covered by the educational programmes offered, including finance, accounting, cost calculation and management. Non-governmental organisations such as the Korea Foundation for SMEs and the Korea Chamber of Commerce and Industry offer courses and seminars in accounting, finance, trade (including exchange risk 
management) as well as practice courses on accounting and tax (including courses focusing on value-added tax, withholding tax, year-end tax adjustments) and various online educational programmes. Coordination between the complex network of Ministries (4) and institutions (460) involved in supporting MSMEs is nevertheless noted as potentially challenging.

\section{Malaysia}

In Malaysia, the SME Info website (http://www.smeinfo.com.my/) run by SME Corporation Malaysia under the Ministry of International Trade and Industry, serves as a 'one-stop information portal' for SME resources on financing, advice, networking opportunities and programmes/initiatives offered by the government and private organisations. SME Corporation provides business advisory and financial support for SMEs through their 'Business Accelerator Programme', which is funded by a Malaysian government grant (Al Mamun and Ekpe, 2016).

Further, Malaysia SME (http://malaysiasme.com.my/) is a media group specialising in providing resources and material (including a newspaper, community directory and online news portal) for SMEs. One of their more innovative initiatives is a TV show called "Small Mission Enterprise", which follows a group of young entrepreneurs and is intended to provide education about the challenges faced by young entrepreneurs in Malaysia in an accessible and light manner.

\section{Portugal}

The three Portuguese financial supervisors (Banco de Portugal, Portuguese Securities Market Commission and Portuguese Insurance and Pension Funds Supervisory Authority) and the Ministry of Economy (through the Public Agency for Competitiveness and Innovation and Public Authority for Tourism) signed a cooperation agreement to support financial education for entrepreneurs, businessowners and managers of micro, small and medium-sized enterprises.

The first challenge was the joint development of the "Core competencies for financial training of micro, small and medium-sized enterprises". These core competencies use the INFE working definition of financial education for MSMEs and define contents on (i) economic and financial system, (ii) establishment and development of the company, (iii) business plan and financial planning; (iv) accounting and economic and financial analysis (v) bank accounts and payment services; (vi) bank financing, characteristics and main products (vii) capital market financing, financial investments and market risk management (vii) insurance, functions and main characteristics, (ix) pension funds and, functions and main characteristics, and (x) fraud prevention.

The core competencies framework also proposes training sessions, around goal setting, financing the business, accounting, economic and financial analysis, risk mitigation and internationalization of the company.

The document was launched for public consultation at the end of 2015, and the feedback received in the process has been included where relevant. From June to September 2016 a set of pilot training sessions with entrepreneurs, business-owners and managers of MSMEs were implemented to assess the suitability of content and training session proposals of the core competencies. With the feedback from pilot training sessions the final version of the "Core competencies for financial training of micro, small and mediumsized enterprises" was released in early November 2016.

Train the trainer sessions will be held between December 2016 and the 1st quarter of 2017. With this training, we intend to gather a large group of certified trainers who can disseminate more widely the financial education in MSMEs. A set of these training sessions for entrepreneurs, business-owners and managers of MSMEs is planned for 2017. 


\section{Serbia}

In Serbia, in addition to the provision through the national strategy for financial education, certain schools and universities provide lectures about entrepreneurship and business, and the National Agency for Regional Development certifies business support providers and organises lectures on topics such as how to start a business, how to develop a business plan and tax management.

\section{Spain}

In Spain, the key stakeholders providing financial education, information and guidance to MSMEs are the Ministry of Employment and Social Security, the Directorate General of Industry and SMEs, regional governments and local authorities and various private banks.

\section{Singapore}

In Singapore a partnership between the financial and university sectors has resulted in the establishment of the United Overseas Bank - Singapore Management University Asian Enterprise Institute (http://usaei.smu.edu.sg/). Initiatives at the centre include:

- SME Learning Portal, a website with resources on business and management topics, interactive toolkits and a community forum in which users can share success stories.

- SME Development Series a monthly speaker series where experts share latest developments and their business know-how.

- SME Consulting Programme, where students from Singapore Management University together with experienced advisers/industry practitioners provide business consultancy services to local enterprises. The service runs for a period of 10-12 weeks and includes consultancy on marketing, customer satisfaction, market research, and business planning, etc.

\section{Turkey}

Some Turkish school students receive entrepreneurship classes through the Junior Achievement programme or Konya, part of the SEECEL project. There are also targeted classes in universities. These include the MSME Management and Entrepreneurship masters class provided by Gebze Technical University and an entrepreneurship programme at the Middle East Technical University.

The TOBB Economy and Technology University offers an innovative MSME Hospital within the KOBI Hastanesi centre. This provides consultancy services and education as required. MSME mentorship is also available through several other universities. The Republic of Turkey Small and Medium Enterprises Development Organisation (KOSGEB) also provides nationwide seminars to MSMEs. It also intends to offer an online campus providing relevant materials in the near future. Financial education is also offered online and through other means as part of the Treasury's start-up funds.

Turkish SMEs also have access to a networking project enacted by the Ministry of Economy and the European Union which helps companies to cooperate and compete. Business Clusters receive technical support to benefit from grant programmes. Other mentoring schemes are also in operation, through the cooperation between stakeholders mentioned above; and particularly universities and chambers of commerce. In addition, a recent project undertaken in cooperation with the private sector and the Ministry of the European Union and the Centre for European Union Programme for Education and Youth provided access to 20 mobile games especially targeting MSMEs in Technology and Science. 
Fee-based services are available to MSMEs in Turkey through Ankara Chamber of Commerce. These focus on strategic planning, human resources management, project management, R\&D and innovation, trademark and patent registration and international trade, as well as tax and related business law. Consultancy on other financial matters, including financial education, is available through private firms providing services to MSMEs.

Certain actors in the financial sector provide free financial education to particular target groups. For example, the Turkish Economy Bank has a platform to education female entrepreneurs through the TEB Women Academy. 


\section{Annex II. Stocktake questionnaire on financial education for MSMEs and potential entrepreneurs}

\section{Background, objective and process}

In 2014 the OECD International Network on Financial Education (OECD/INFE) Advisory Board and its Technical Committee agreed that the OECD/INFE should focus on financial education for entrepreneurs and small business owners (owners of micro, small or medium-sized enterprises; or MSMEs) through a dedicated Expert Subgroup, in accordance with the revised key directions for the OECD/INFE Technical Committee Activities in 2015-2016. The Subgroup had its first meeting in May 2015, and agreed on a programme of work spanning two years in the first instance, beginning with a comprehensive stock take of current provision of financial education among OECD/INFE countries.

The main focus of this stock take is on micro and small enterprises (with a suggested maximum of 100 employees), and potential entrepreneurs (i.e. individuals with potential business ideas who are close to taking their ideas to the market). The questionnaire is designed to take stock of policy challenges, current provision of financial education and gaps in provision for these target audiences among OECD/INFE members.

The questionnaire has been approved by subgroup members through the written process for circulation to all OECD/INFE members for completion.

Results of this stocktake will be used to inform a dedicated report on the status of financial education for MSMEs and potential entrepreneurs as well as to develop policy and practical guidance. 


\section{Scope and Definition}

This questionnaire focuses on financial education for micro, small and medium-sized enterprises (MSMEs), and particularly micro and small enterprises (with a suggested maximum of 100 employees), or potential entrepreneurs (i.e. individuals with potential business ideas who are close to taking their ideas to the market) across OECD/INFE member countries.

1. The OECD definition of Financial Education (approved by G20) is the process by which financial consumers/investors improve their understanding of financial products, concepts and risks and, through information, instruction and/or objective advice, develop the skills and confidence to become more aware of financial risks and opportunities, to make informed choices, to know where to go for help, and to take other effective actions to improve their financial well-being.

2. For the sake of this questionnaire, the following working definition of financial education for MSMEs and potential entrepreneurs will be used:

Financial education for MSMEs and potential entrepreneurs takes into account different types of business and stages of enterprises, and refers to the process by which they:

- $\quad$ Recognise the interaction between personal and business finance;

- Know where to go for help;

- Improve their understanding of the financial landscape, products and concepts of relevance; and

- Through information, instruction and/or objective advice, develop the skills, knowledge, attitudes and confidence to:

- become more aware of financing opportunities and financial risks and opportunities; make informed business plans and related choices;

manage their financial records, planning and risks effectively over the short and long term; and

- take other effective actions to maximise the potential of their business for the benefit of their enterprise and that of the wider economy. 


\section{I- General information on enterprises}

Q1. Do you have official definitions of enterprise size in your jurisdiction? If these vary by sector, geographical location, or other factors, please describe. [Please provide as much information as you can, particularly on micro and small enterprises].

\begin{tabular}{|l|l|l|l|l|}
\hline Q1. & General definition & $\begin{array}{l}\text { Variations by } \\
\text { Sector }\end{array}$ & $\begin{array}{l}\text { Variations by } \\
\text { geographical location }\end{array}$ & Other variations \\
\hline Micro enterprises & & & & \\
\hline Small enterprises & & & & \\
\hline $\begin{array}{l}\text { Medium-sized } \\
\text { enterprises }\end{array}$ & & & & \\
\hline MSMEs in general & & & & \\
\hline
\end{tabular}

Please provide links to definitions in the public domain.

Q2. Please complete as many cells as possible in the table below with responses to the following questions:

Q2.1. How many enterprises are there in your country in total?

Q2.2. What proportion of GDP do they contribute?

Q2.3. What proportion of employment do they contribute?

Q2.4. What is the survival rate of enterprises in your country (the proportion of enterprises in existence in year 1 that are still in business in year 2)?

Q2.5. What proportion use the services of a financial expert or financial director?

\begin{tabular}{|l|l|l|l|l|l|}
\hline Q2. & $\begin{array}{l}\text { Q2.1 } \\
\text { Total number }\end{array}$ & $\begin{array}{l}\text { Q2.2 } \\
\text { \% of GDP }\end{array}$ & $\begin{array}{l}\text { Q2.3 } \\
\text { \% of employment }\end{array}$ & $\begin{array}{l}\text { q2.4 } \\
\text { Survival rate }\end{array}$ & $\begin{array}{l}\text { Q2.5 } \\
\%\end{array}$ \\
\hline Micro enterprises & & & & & \\
\hline Small enterprises & & & & & \\
\hline $\begin{array}{l}\text { Medium-sized } \\
\text { enterprises }\end{array}$ & & & & & \\
\hline All MSMEs & & & & & \\
\hline All companies & & & & & \\
\hline
\end{tabular}

Please provide information about the sources and dates of these data. 


\section{II- Policy priorities and challenges for MSMEs and potential entrepreneurs}

Q3. What are the main policy priorities/concerns/restrictions in relation to MSMEs and potential entrepreneurs at different life stages? Please fill in the following table by checking the boxes that apply, and providing any comment and links to available research. If issues are only related to some types of enterprise or some industries, please provide further information in the detailed comments

\begin{tabular}{|c|c|c|c|c|c|}
\hline \multicolumn{6}{|l|}{ Q3. Main policy priorities/concerns } \\
\hline Policy priorities/concerns & $\begin{array}{c}\text { Potential } \\
\text { entrepreneurs }\end{array}$ & $\begin{array}{l}\text { Newly established } \\
\text { MSMEs }\end{array}$ & $\begin{array}{l}\text { MSMEs in the } \\
\text { Growth Stage }\end{array}$ & $\begin{array}{l}\text { MSMEs in the } \\
\text { Maturity Stage }\end{array}$ & $\begin{array}{l}\text { Details, comments and links to } \\
\text { available research or data }\end{array}$ \\
\hline \multicolumn{6}{|c|}{ I. Business Landscape } \\
\hline $\begin{array}{l}\text { Aspects of regulation causing barriers to } \\
\text { start-up/growth of enterprise }\end{array}$ & $\square$ & $\square$ & $\square$ & $\square$ & \\
\hline $\begin{array}{l}\text { Structuring and providing incentives for } \\
\text { investment in MSMEs }\end{array}$ & $\square$ & $\square$ & $\square$ & $\square$ & \\
\hline Lack of access to business finance & $\square$ & $\square$ & $\square$ & $\square$ & \\
\hline Lack of financing options & $\square$ & $\square$ & $\square$ & $\square$ & \\
\hline Lack of support and guidance for MSMEs & $\square$ & $\square$ & $\square$ & $\square$ & \\
\hline Other (please specify) & $\square$ & $\square$ & $\square$ & $\square$ & \\
\hline \multicolumn{6}{|c|}{ II. Skills, Knowledge and Experience of Managers/Owners } \\
\hline \multicolumn{6}{|l|}{$\begin{array}{l}\text { Financial literacy and inclusion of would- } \\
\text { be and current owners/managers }\end{array}$} \\
\hline Lack of individual financial literacy & $\square$ & $\square$ & $\square$ & $\square$ & \\
\hline Financial exclusion & $\square$ & $\square$ & $\square$ & $\square$ & \\
\hline Lack of awareness of financing options & $\square$ & $\square$ & $\square$ & $\square$ & \\
\hline $\begin{array}{l}\text { Lack of knowledge on the financing } \\
\text { options }\end{array}$ & $\square$ & $\square$ & $\square$ & $\square$ & \\
\hline Complexity of financing options & $\square$ & $\square$ & $\square$ & $\square$ & \\
\hline
\end{tabular}




\begin{tabular}{|l|c|c|c|c|c|}
\hline \multicolumn{1}{|c|}{ Q3. Main policy priorities/concerns } & $\begin{array}{c}\text { Potential } \\
\text { entrepreneurs }\end{array}$ & $\begin{array}{c}\text { Newly established } \\
\text { MSMEs }\end{array}$ & $\begin{array}{c}\text { MSMEs in the } \\
\text { Growth Stage }\end{array}$ & $\begin{array}{c}\text { MSMEs in the } \\
\text { Maturity Stage }\end{array}$ & $\begin{array}{c}\text { Details, comments and links to } \\
\text { available research or data }\end{array}$ \\
\hline $\begin{array}{l}\text { Business and entrepreneurial skills of } \\
\text { would-be and current owners/managers }\end{array}$ & & & & & \\
\hline Lack of general entrepreneurial skills & $\square$ & $\square$ & $\square$ & $\square$ & \\
\hline Lack of business acumen & $\square$ & $\square$ & $\square$ & $\square$ & \\
\hline Lack of specific, sector-relevant skills & $\square$ & $\square$ & $\square$ & $\square$ & \\
\hline Lack of management skills & $\square$ & $\square$ & $\square$ & $\square$ & \\
\hline Other (please specify) & $\square$ & $\square$ & $\square$ & $\square$ & \\
\hline
\end{tabular}

Q4. Please provide further information about the main policy priorities and concerns related to the following industries: [Please provide as much information as you can, focusing particularly on micro and small enterprises].

\begin{tabular}{|l|l|l|l|}
\hline Q4. & Business landscape & $\begin{array}{l}\text { Financial literacy and } \\
\text { inclusion }\end{array}$ & Business and entrepreneurial skills \\
\hline Agriculture & & & \\
\hline Manufacturing & & & \\
\hline Services and retail & & & \\
\hline Technology & & & \\
\hline Other (please specify) & & \\
\hline
\end{tabular}




\section{Strategic framework for the support of MSMEs and potential entrepreneurs}

Q5 Does your country attempt to measure/quantify the financial literacy levels of MSMEs and potential entrepreneurs?

$\square$ Yes, in a

comprehensive manner<smiles>[As]C12CCC1CC2</smiles>

some extent

If "Yes", please provide further information (e.g. description of the relevant target groups, frequency of data collection, questions used).

Q6.1 Does your country address the financial education needs of MSMEs and potential entrepreneurs through a National Strategy for Financial Education?

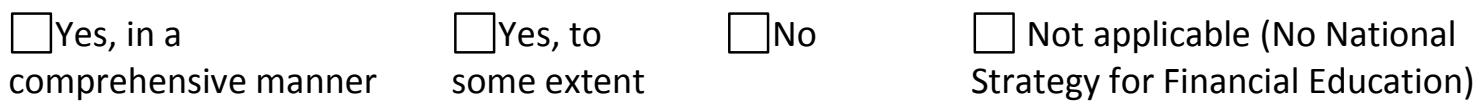

If "Yes", please provide further information including a description of the relevant target groups.

Q6.2 Does your country address the financial education needs of MSMEs and potential entrepreneurs through another policy framework?

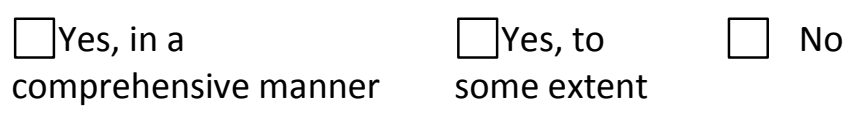

If "Yes", please provide further information including a description of the relevant target groups and the name of the policy framework.

Q7. If yes at 6.1 or 6.2 , is the provision of financial education intended to help to meet the following policy aims?

\begin{tabular}{|l|c|c|c|c|}
\hline \multicolumn{1}{|c|}{$\checkmark$ Q7. Policy aims } \\
\hline \multicolumn{1}{|c|}{$\checkmark$ as appropriate. } & $\begin{array}{c}\text { Potential } \\
\text { entrepreneurs }\end{array}$ & $\begin{array}{c}\text { Micro } \\
\text { enterprises }\end{array}$ & $\begin{array}{c}\text { Small } \\
\text { enterprises }\end{array}$ & $\begin{array}{c}\text { Medium-sized } \\
\text { enterprises }\end{array}$ \\
\hline $\begin{array}{l}\text { Reduce demand-side barriers to accessing } \\
\text { finance }\end{array}$ & $\square$ & $\square$ & $\square$ & $\square$ \\
\hline $\begin{array}{l}\text { Encourage and increasing sustainable } \\
\text { entrepreneurship }\end{array}$ & $\square$ & $\square$ & $\square$ & $\square$ \\
\hline Increase economic stability & $\square$ & $\square$ & $\square$ & $\square$ \\
\hline Increase formal sector employment/activity & $\square$ & $\square$ & $\square$ & $\square$ \\
\hline Increase tax revenues & $\square$ & $\square$ & $\square$ & $\square$ \\
\hline Other (Please specify) & $\square$ & $\square$ & $\square$ & $\square$ \\
\hline
\end{tabular}




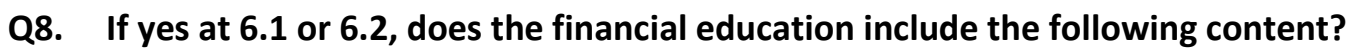

\section{Q8. Content of strategic approaches to financial education across different sized enterprises}

\begin{tabular}{|l|c|c|c|c|}
\hline \multicolumn{1}{|c|}{$\checkmark$ as appropriate. } & $\begin{array}{c}\text { Potential } \\
\text { entrepreneurs }\end{array}$ & $\begin{array}{c}\text { Micro } \\
\text { enterprises }\end{array}$ & $\begin{array}{c}\text { Small } \\
\text { enterprises }\end{array}$ & $\begin{array}{c}\text { Medium-sized } \\
\text { enterprises }\end{array}$ \\
\hline General financial literacy & $\square$ & $\square$ & $\square$ & $\square$ \\
\hline $\begin{array}{l}\text { Recognising the interaction between } \\
\text { personal and business finance }\end{array}$ & $\square$ & $\square$ & $\square$ & $\square$ \\
\hline $\begin{array}{l}\text { Knowing where to go for help on financial } \\
\text { matters }\end{array}$ & $\square$ & $\square$ & $\square$ & $\square$ \\
\hline $\begin{array}{l}\text { Understanding the business, financial and } \\
\text { economic landscapes }\end{array}$ & $\square$ & $\square$ & $\square$ & $\square$ \\
\hline Planning and managing business finances & $\square$ & $\square$ & $\square$ & $\square$ \\
\hline Managing financial records & $\square$ & $\square$ & $\square$ & $\square$ \\
\hline Being aware of financing opportunities & $\square$ & $\square$ & $\square$ \\
\hline $\begin{array}{l}\text { Knowing how to interact with investors and } \\
\text { lenders }\end{array}$ & $\square$ & $\square$ & $\square$ & $\square$ \\
\hline $\begin{array}{l}\text { Knowing how to meet the requirements of } \\
\text { investors and lenders }\end{array}$ & $\square$ & $\square$ & $\square$ & $\square$ \\
\hline $\begin{array}{l}\text { Being aware of financial risks and } \\
\text { opportunities, and managing them } \\
\text { effectively }\end{array}$ & $\square$ & $\square$ & $\square$ & $\square$ \\
\hline Other (Please specify) & $\square$ & $\square$ & $\square$ \\
\hline
\end{tabular}




\section{Practical support and guidance for MSMEs and potential entrepreneurs}

Q9.1. To what extent are the following stakeholders providing financial education, information or guidance to MSMEs or potential entrepreneurs? Please note whether financial education programmes are on a large/national scale, or more local in nature.

\begin{tabular}{|l|c|c|c|c|c|c|c|c|}
\hline \multicolumn{1}{|c|}{$\checkmark$ as appropriate } & \multicolumn{2}{c|}{$\begin{array}{c}\text { Potential } \\
\text { entrepreneurs }\end{array}$} & \multicolumn{2}{c|}{ Micro enterprises } & \multicolumn{2}{c|}{ Small enterprises } & \multicolumn{2}{c|}{$\begin{array}{c}\text { Medium-sized } \\
\text { enterprises }\end{array}$} \\
\hline & $\begin{array}{c}\text { Large/ } \\
\text { National }\end{array}$ & Local & $\begin{array}{c}\text { Large/ } \\
\text { National }\end{array}$ & Local & $\begin{array}{c}\text { Large/ } \\
\text { National }\end{array}$ & Local & $\begin{array}{c}\text { Large/ } \\
\text { National }\end{array}$ & Local \\
\hline \begin{tabular}{l} 
Public $\begin{array}{l}\text { sector/Government } \\
\text { (excluding education) }\end{array}$ \\
\hline $\begin{array}{l}\text { Education sector } \\
\text { (universities/colleges) }\end{array}$
\end{tabular} & $\square$ & $\square$ & $\square$ & $\square$ & $\square$ & $\square$ & $\square$ \\
\hline $\begin{array}{l}\text { Industry/trade union } \\
\text { organisations }\end{array}$ & $\square$ & $\square$ & $\square$ & $\square$ & $\square$ & $\square$ & $\square$ & $\square$ \\
\hline $\begin{array}{l}\text { Other national or } \\
\text { regional civil sector } \\
\text { (charities/not-for- } \\
\text { profits) }\end{array}$ & $\square$ & $\square$ & $\square$ & $\square$ & $\square$ & $\square$ & $\square$ & $\square$ \\
\hline Financial sector & $\square$ & $\square$ & $\square$ & $\square$ & $\square$ & $\square$ & $\square$ & $\square$ \\
\hline $\begin{array}{l}\text { International not-for- } \\
\text { profits/NGOs }\end{array}$ & $\square$ & $\square$ & $\square$ & $\square$ & $\square$ & $\square$ & $\square$ & $\square$ \\
\hline \begin{tabular}{l} 
Other (please specify) \\
\hline
\end{tabular} & $\square$ & $\square$ & $\square$ & $\square$ & $\square$ & $\square$ & $\square$ & $\square$ \\
\hline
\end{tabular}


Q9.2. Please list the main stakeholders providing financial education, information or guidance to MSMEs or potential entrepreneurs, and identify the provision available

$\checkmark$ as appropriate [Please provide as much information as you can, focusing particularly on micro and small enterprises].

\begin{tabular}{|c|c|c|c|c|c|c|c|c|c|}
\hline \multicolumn{5}{|c|}{$\begin{array}{l}\text { Q9.2. Key stakeholder support to MSMEs and potential } \\
\text { entrepreneurs }\end{array}$} & & & & & \\
\hline \multirow{13}{*}{$\begin{array}{l}\text { Name } \\
\text { of } \\
\text { stakeho } \\
\text { Ider }\end{array}$} & $\begin{array}{c}\text { Sector } \\
\text { (public/private } \\
\text { /NGO/ } \\
\text { International }\end{array}$ & $\begin{array}{c}\text { Stakeho } \\
\text { Ider } \\
\text { provide } \\
\text { s } \\
\text { busines } \\
\text { s }\end{array}$ & $\begin{array}{l}\text { Stakeholder } \\
\text { provides } \\
\text { entreprene }\end{array}$ & $\begin{array}{c}\text { Stakeho } \\
\text { Ider } \\
\text { provide } \\
\text { s }\end{array}$ & $\begin{array}{c}\text { Size of } \\
\text { enterprise } \\
\text { targeted }\end{array}$ & \multicolumn{4}{|c|}{ Target group } \\
\hline & & & & & $\begin{array}{l}\text { Micro/small/ } \\
\text { medium }\end{array}$ & $\begin{array}{l}\text { You } \\
\text { th }\end{array}$ & $\begin{array}{l}\text { Wom } \\
\text { en }\end{array}$ & $\begin{array}{l}\text { Un- } \\
\text { emplo } \\
\text { yed }\end{array}$ & $\begin{array}{l}\text { Othe } \\
r \\
\text { (plea } \\
\text { se } \\
\text { speci } \\
\text { fy) }\end{array}$ \\
\hline & & $\square$ & $\square$ & $\square$ & & $\square$ & $\square$ & $\square$ & \\
\hline & & $\square$ & $\square$ & $\square$ & & $\square$ & $\square$ & $\square$ & \\
\hline & & $\square$ & $\square$ & $\square$ & & $\square$ & $\square$ & $\square$ & \\
\hline & & $\square$ & $\square$ & $\square$ & & $\square$ & $\square$ & $\square$ & \\
\hline & & $\square$ & $\square$ & $\square$ & & $\square$ & $\square$ & $\square$ & \\
\hline & & $\square$ & $\square$ & $\square$ & & $\square$ & $\square$ & $\square$ & \\
\hline & & $\square$ & $\square$ & $\square$ & & $\square$ & $\square$ & $\square$ & \\
\hline & & $\square$ & $\square$ & $\square$ & & $\square$ & $\square$ & $\square$ & \\
\hline & & $\square$ & $\square$ & $\square$ & & $\square$ & $\square$ & $\square$ & \\
\hline & & $\square$ & $\square$ & $\square$ & & $\square$ & $\square$ & $\square$ & \\
\hline & & $\square$ & $\square$ & $\square$ & & $\square$ & $\square$ & $\square$ & \\
\hline
\end{tabular}


Q10. Is financial education, information or guidance available through any of the following delivery channels?

$\checkmark$ as appropriate

\begin{tabular}{|c|c|c|c|c|c|}
\hline $\begin{array}{l}\text { Q10. Main delivery } \\
\text { channels }\end{array}$ & $\begin{array}{c}\text { Potential } \\
\text { entrepreneurs }\end{array}$ & $\begin{array}{c}\text { Micro } \\
\text { enterprises }\end{array}$ & $\begin{array}{c}\text { Small } \\
\text { enterprises }\end{array}$ & $\begin{array}{c}\text { Medium- } \\
\text { sized } \\
\text { enterprises }\end{array}$ & $\begin{array}{l}\text { Please describe or provide links } \\
\text { to further information }\end{array}$ \\
\hline \multicolumn{6}{|l|}{$\begin{array}{l}\text { Formal, face-to- } \\
\text { face education }\end{array}$} \\
\hline $\begin{array}{l}\text { Financial education } \\
\text { with } \\
\text { entrepreneurship } \\
\text { in schools }\end{array}$ & $\square$ & & & & \\
\hline $\begin{array}{l}\text { Financial education } \\
\text { with } \\
\text { entrepreneurship } \\
\text { in universities }\end{array}$ & $\square$ & & & & \\
\hline $\begin{array}{l}\text { Financial education } \\
\text { provided by } \\
\text { universities } \\
\text { [including in MBA } \\
\text { courses, for } \\
\text { example] }\end{array}$ & $\square$ & $\square$ & $\square$ & $\square$ & \\
\hline $\begin{array}{l}\text { Formal financial } \\
\text { education courses } \\
\text { or seminars with a } \\
\text { trained/qualified } \\
\text { trainer [Not in } \\
\text { schools or } \\
\text { universities] }\end{array}$ & $\square$ & $\square$ & $\square$ & $\square$ & \\
\hline \multicolumn{6}{|l|}{$\begin{array}{l}\text { Informal, face-to- } \\
\text { face education }\end{array}$} \\
\hline $\begin{array}{l}\text { Ad hoc/drop-in } \\
\text { seminars with a } \\
\text { trained/qualified } \\
\text { trainer }\end{array}$ & $\square$ & $\square$ & $\square$ & $\square$ & \\
\hline $\begin{array}{l}\text { Ad hoc/drop-in } \\
\text { seminars with a } \\
\text { peer educator }\end{array}$ & $\square$ & $\square$ & $\square$ & $\square$ & \\
\hline \multicolumn{6}{|l|}{$\begin{array}{l}\text { Face-to-face advice } \\
\text { and guidance }\end{array}$} \\
\hline $\begin{array}{l}\text { Paid-for advice } \\
\text { from public sector }\end{array}$ & $\square$ & $\square$ & $\square$ & $\square$ & \\
\hline $\begin{array}{l}\text { Free advice from } \\
\text { public sector }\end{array}$ & $\square$ & $\square$ & $\square$ & $\square$ & \\
\hline $\begin{array}{l}\text { Paid-for advice } \\
\text { from charity/NGO }\end{array}$ & $\square$ & $\square$ & $\square$ & $\square$ & \\
\hline Free advice from & $\square$ & $\square$ & $\square$ & $\square$ & \\
\hline
\end{tabular}




\begin{tabular}{|c|c|c|c|c|c|}
\hline $\begin{array}{l}\text { Q10. Main delivery } \\
\text { channels }\end{array}$ & $\begin{array}{c}\text { Potential } \\
\text { entrepreneurs }\end{array}$ & $\begin{array}{l}\text { Micro } \\
\text { enterprises }\end{array}$ & $\begin{array}{c}\text { Small } \\
\text { enterprises }\end{array}$ & $\begin{array}{l}\text { Medium- } \\
\text { sized } \\
\text { enterprises }\end{array}$ & $\begin{array}{l}\text { Please describe or provide links } \\
\text { to further information }\end{array}$ \\
\hline \multicolumn{6}{|l|}{ charity/NGO } \\
\hline $\begin{array}{l}\text { Paid-for advice } \\
\text { from business } \\
\text { sector }\end{array}$ & $\square$ & $\square$ & $\square$ & $\square$ & \\
\hline $\begin{array}{l}\text { Free advice from } \\
\text { business sector }\end{array}$ & $\square$ & $\square$ & $\square$ & $\square$ & \\
\hline $\begin{array}{l}\text { Paid-for advice } \\
\text { from financial } \\
\text { sector }\end{array}$ & $\square$ & $\square$ & $\square$ & $\square$ & \\
\hline $\begin{array}{l}\text { Free advice from } \\
\text { financial sector }\end{array}$ & $\square$ & $\square$ & $\square$ & $\square$ & \\
\hline $\begin{array}{l}\text { Free guidance } \\
\text { and/or mentoring } \\
\text { from other } \\
\text { entrepreneurs }\end{array}$ & $\square$ & $\square$ & $\square$ & $\square$ & \\
\hline \multicolumn{6}{|l|}{ Other } \\
\hline $\begin{array}{l}\text { Printed leaflets and } \\
\text { brochures }\end{array}$ & $\square$ & $\square$ & $\square$ & $\square$ & \\
\hline $\begin{array}{l}\text { Formal online } \\
\text { courses }\end{array}$ & $\square$ & $\square$ & $\square$ & $\square$ & \\
\hline $\begin{array}{l}\text { Learning } \\
\text { applications for } \\
\text { phones/tablets }\end{array}$ & $\square$ & $\square$ & $\square$ & $\square$ & \\
\hline $\begin{array}{l}\text { Social media } \\
\text { interventions }\end{array}$ & $\square$ & $\square$ & $\square$ & $\square$ & \\
\hline $\begin{array}{l}\text { TV/media } \\
\text { interventions }\end{array}$ & $\square$ & $\square$ & $\square$ & $\square$ & \\
\hline $\begin{array}{l}\text { Other delivery } \\
\text { channel (please } \\
\text { specify) }\end{array}$ & $\square$ & $\square$ & $\square$ & $\square$ & \\
\hline
\end{tabular}


Q11. If any stakeholders provide financial education to MSMEs and potential entrepreneurs, please complete the following $\mathbf{2}$ tables for up to three key initiatives, focusing on those that are national in scope, have been shown to have a large impact, or are unique in an important way. ${ }^{9}$

\begin{tabular}{|l|l|l|l|}
\hline \multicolumn{1}{|c|}{$\checkmark$ Q11.1. Description of financial education initiatives } & \multicolumn{1}{l|}{ Initiative 2 } & Initiative 3 \\
\hline Name of initiative and start date & & & \\
\hline $\begin{array}{l}\text { Organisation(s) responsible for the } \\
\text { initiative }\end{array}$ & & & \\
\hline $\begin{array}{l}\text { Type of coverage } \\
\text { (International/National/Regional) }\end{array}$ & & & \\
\hline $\begin{array}{l}\text { Organisation(s) funding the initiative, } \\
\text { and cost per participant (if known) }\end{array}$ & & & \\
\hline $\begin{array}{l}\text { Organisation(s) designing and } \\
\text { delivering the financial education }\end{array}$ & & & \\
\hline $\begin{array}{l}\text { Objective of the programme } \\
\text { (Intended/Desired effect) }\end{array}$ & & & \\
\hline Types of delivery methods & & & \\
\hline Intended target audience & & & \\
\hline $\begin{array}{l}\text { Actual recipients (if different from } \\
\text { target audience) }\end{array}$ & & & \\
\hline Topics covered & & & \\
\hline
\end{tabular}

9 If you do not have the information available, please provide contact details or the web address of the organisation responsible. 


\section{Q11.2. Evaluation of relevant financial education initiatives}

\begin{tabular}{|l|l|l|l|}
\hline \multicolumn{1}{|c|}{$\checkmark$ as appropriate } & \multicolumn{1}{c|}{ Initiative 1 } & Initiative 2 & Initiative 3 \\
\hline Type of evaluation evidence collected & & & \\
\hline $\begin{array}{l}\text { Changes observed in awareness, } \\
\text { knowledge, behaviour identified after } \\
\text { the implementation }\end{array}$ & & & \\
\hline $\begin{array}{l}\text { Changes observed in the number of } \\
\text { MSMEs, the size or earnings of } \\
\text { MSMEs or the survival rate of MSMEs } \\
\text { identified after the implementation }\end{array}$ & & & \\
\hline $\begin{array}{l}\text { Challenges faced and solutions found } \\
\text { during the implementation }\end{array}$ & & & \\
\hline
\end{tabular}

Q12. What lessons can be drawn from the provision of financial education in your country? Please provide details.

Q13. Do you have any other comments or information that you believe would be useful to this stocktake exercise? Please provide details. 


\section{WORKING PAPERS PUBLISHED TO DATE}

The full series is listed below in chronological order. Prior to March 2010, the series was named OECD Working Papers on Insurance and Private Pensions. All working papers can be accessed online at: www.oecd.org/daf/fin/wp.

WP.42: Behavioural Economics and Financial Consumer Protection

2016

WP.41: Unleasing the Export Potential of SMEs in Greece

WP.40: Financial Education Policies in Asia and the Pacific

2015

WP39: Financial Education for Long-term Savings and Investments: A Review of Research and Literature

WP38: Financial Education for Migrants and their Families

WP37: The Bitcoin Question: Currency versus Trust-less Transfer Technology

2013

WP36: Institutional Investors and Infrastructure Financing

WP35: Institutional Investors and Green Infrastructure Investments: selected case studies

WP34: Promoting Financial Inclusion through Financial Education

WP33: Financial Education in Latin America and the Caribbean

WP32: Pension Fund Investment in Infrastructure: A Comparison between Australia and Canada

WP31: Policyholder Protection Schemes: Selected Considerations

WP30: The Effect of Solvency Regulations and Accounting Standards on Long-Term Investing

WP29: Trends in Large Pension Fund Investment in Infrastructure

WP28: Communicating Pension Risk to DC Plan Members: The Chilean Case of a Pension Risk Simulator

WP27: The Role of Funded Pensions in Retirement Income Systems: Issues for the Russian Federation

WP26: Infrastructure Investment in New Markets: Challenges and Opportunities for Pension Funds

WP25: The Status of Financial Education in Africa

WP24: Defining and Measuring Green Investments: Implications for Institutional Investors' Asset Allocations

WP23: The Role of Institutional Investors in Financing Clean Energy

WP22: Financial Education, Savings and Investments

WP21: Identification and Assessment of Publicly Available Data Sources to Calculate Indicators of Private Pensions 
WP20: Coverage of Private Pensions Systems: Evidence and Policy Options

WP19: Annual DC Pension Statements and the Communications Challenge

WP18: Lessons from National Pensions Communication Campaigns

WP17: Review of the Swedish National Pension Funds

WP16: Current Status of National Strategies for Financial Education

WP15: Measuring Financial Literacy: Results of the OECD International Network on Financial Education Pilot Study

WP14: Empowering Women through Financial Awareness and Education

WP13: Pension Fund Investment in Infrastructure: Policy Actions

WP12: Designing Optimal Risk Mitigation and Risk Transfer Mechanisms to Improve the Management of Earthquake Risk in Chile

2011

WP11: The Role of Guarantees in Defined Contribution Pensions

WP10: The Role of Pension Funds in Financing Green Growth Initiatives

WP9: Catastrophe Financing for Governments

WP8: Funding in Public Sector Pension Plans - International Evidence

WP7: Reform on Pension Fund Governance and Management: The 1998 Reform of Korea National Pension Fund

2010

WP6: Options to Improve the Governance and Investment of Japan's Government Pension Investment Fund

WP5: The New IAS 19 Exposure Draft

WP4: The EU Stress Test and Sovereign Debt Exposures

WP3: The Impact of the Financial Crisis on Defined Benefit Plans and the Need for CounterCyclica Funding Regulations

WP2: Assessing Default Investment Strategies in Defined Contribution Pension Plans

WP1: Framework for the Development of Financial Literacy Baseline Surveys: A First International Comparative Analysis

\section{OECD Working Papers on Insurance and Private Pensions}

WP41: Policy Action in Private Occupational Pensions in Japan since the Economic Crisis of the 1990s

WP40: Pension Funds' Risk-management Framework: Regulation and Supervisory Oversight

WP38: Managing Investment Risk in Defined Benefit Pension Funds

WP37: Investment Regulations and Defined Contribution Pensions

WP36: Private Pensions and Policy Responses to the Financial and Economic Crisis

WP35: Defined-contribution (DC) arrangements in Anglo-Saxon Countries

WP34: Evaluating the Design of Private Pension Plans

WP33: Licensing Regulation and the Supervisory Structure of Private Pensions

WP32: Pension Fund Investment in Infrastructure 
WP31: Pension Coverage and Informal Sector Workers

WP30: Pensions in Africa

WP29: Ageing and the Payout Phase of Pensions, Annuities and Financial Markets

2008

WP27: Fees in Individual Account Pension Systems

WP26: Forms of Benefit Payment at Retirement

WP25: Policy Options for the Payout Phase

WP24: National Annuity Markets

WP23: Accounting for Defined Benefit Plans

WP22: Description of Private Pension Systems

WP21: Comparing Aggregate Investment Returns in Privately Managed Pension Funds

WP20: Pension Fund Performance

WP19: Coverage of Funded Pension Plans

WP18: Pension Fund Governance

WP17: Funding Regulations and Risk Sharing

WP16: Evaluating the Impact of Risk Based Funding Requirements on Pension Funds

WP15: Governance and Investment of Public Pension Reserve Funds in Selected OECD Countries

WP14: Sovereign Wealth and Pension Fund Issues

2007

WP13: Reforming the Valuation and Funding of Pension Promises

WP12: Pension Fund Investment in Hedge Funds

WP11: Implications of Behavioural Economics for Mandatory Individual Account Pension Systems

WP10: Portfolio Investment in an Intertemporal Setting

WP9: Collective Pension Funds

WP8: Pension Fund Regulation and Risk Management

WP7: Survey of Investment Choice by Pension Fund Members

WP6: Benefit Protection

WP5: Benefit Security Pension Fund Guarantee Schemes

WP4: Governments and the Market for Longevity-Indexed Bonds

WP3: Longevity Risk and Private Pensions

WP2: Policy Issues for Developing Annuities Markets

WP1: Funding Rules and Actuarial Methods 